Fire Patterns in the Range of the Greater Sage-Grouse, 1984-2013 - Implications for Conservation and Management

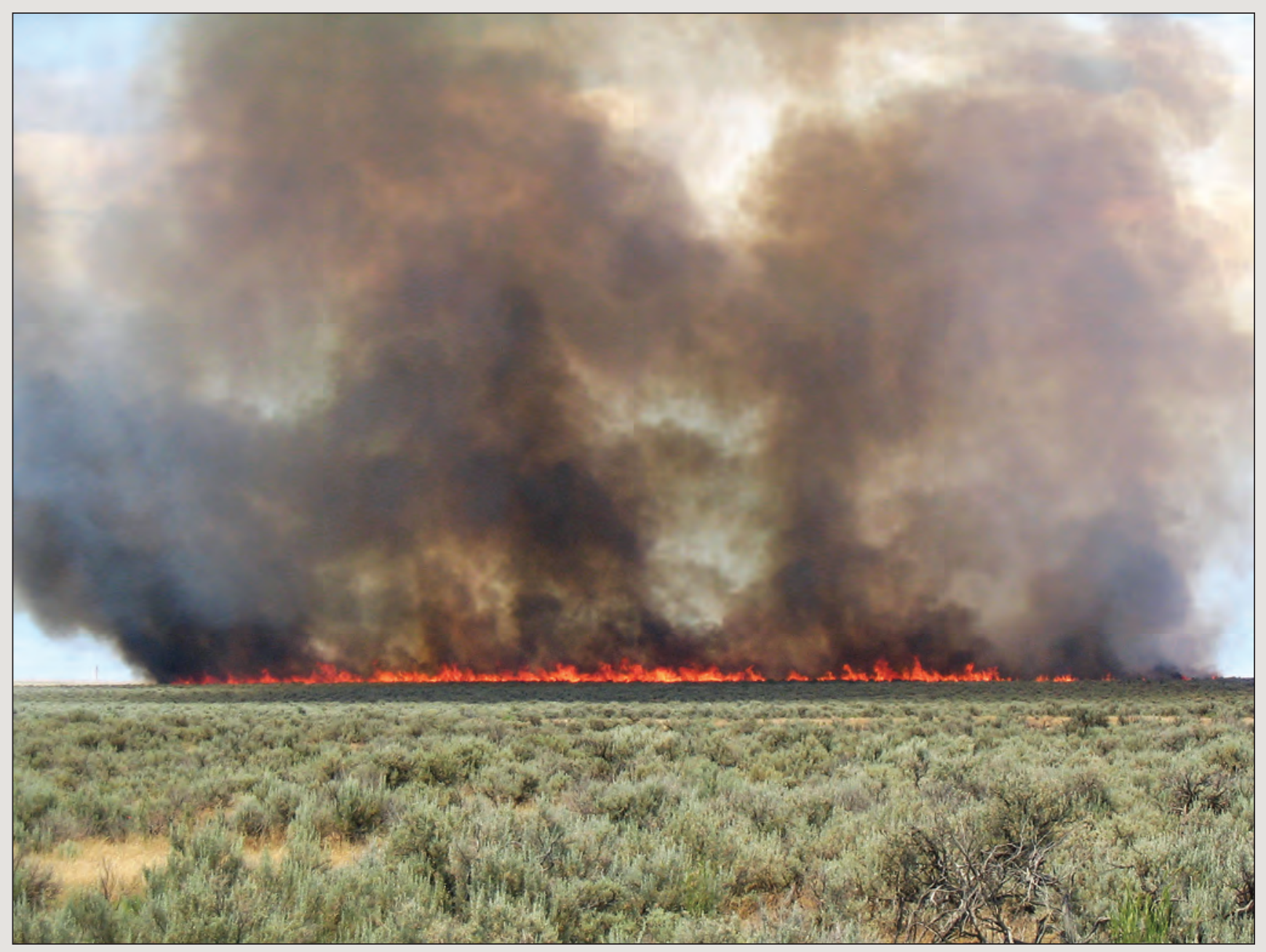

Open-File Report 2015-1167 
Cover: Fire in sagebrush shrubland, southwestern Idaho, June 2010.

Photograph by Douglas J. Shinneman, U.S. Geological Survey. 


\section{Fire Patterns in the Range of the Greater Sage-Grouse, 1984-2013-Implications for Conservation and Management}

By Matthew L. Brooks, John R. Matchett, Douglas J. Shinneman, and Peter S. Coates

Open-File Report 2015-1167

U.S. Department of the Interior

U.S. Geological Survey 


\section{U.S. Department of the Interior \\ SALLY JEWELL, Secretary}

\section{U.S. Geological Survey \\ Suzette M. Kimball, Acting Director}

U.S. Geological Survey, Reston, Virginia: 2015

For more information on the USGS—-the Federal source for science about the Earth, its natural and living resources, natural hazards, and the environment-visit http://www.usgs.gov/ or call 1-888-ASK-USGS (1-888-275-8747).

For an overview of USGS information products, including maps, imagery, and publications, visit http://www.usgs.gov/pubprod/.

Any use of trade, firm, or product names is for descriptive purposes only and does not imply endorsement by the U.S. Government.

Although this information product, for the most part, is in the public domain, it also may contain copyrighted materials as noted in the text. Permission to reproduce copyrighted items must be secured from the copyright owner.

Suggested citation:

Brooks, M.L., Matchett, J.R., Shinneman, D.J., and Coates, P.S., 2015, Fire patterns in the range of greater sagegrouse, 1984-2013-Implications for conservation and management: U.S. Geological Survey Open-File Report 2015-1167, 66 p., http://dx.doi.org/10.3133/ofr20151167.

ISSN 2331-1258 (online) 


\section{Contents}

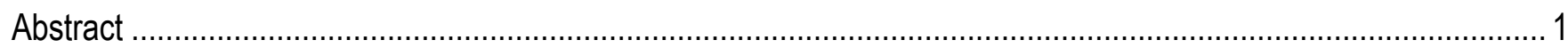

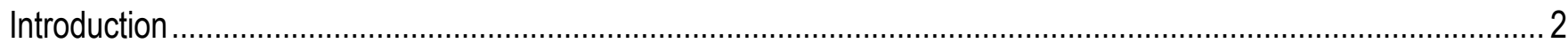

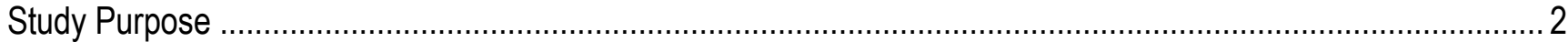

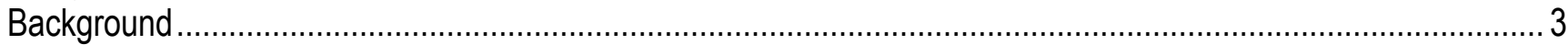

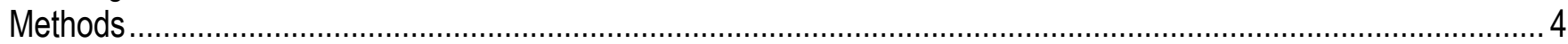

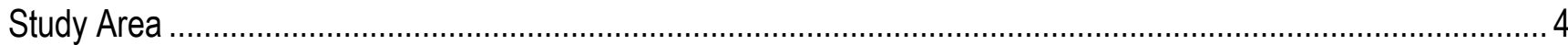

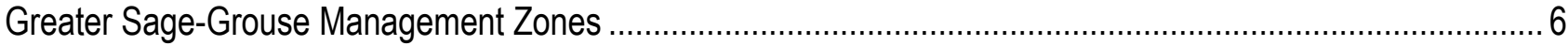

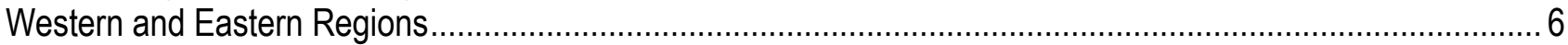

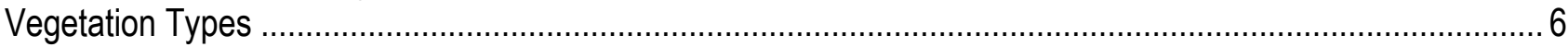

Soil Temperature and Moisture Regimes as Indicators of Resilience/Resistance ........................................... 10

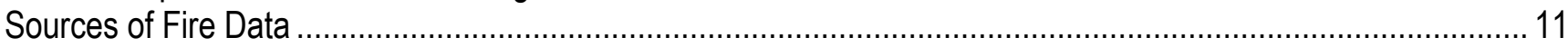

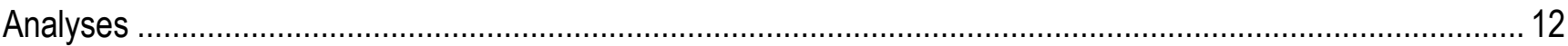

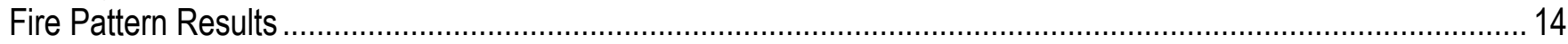

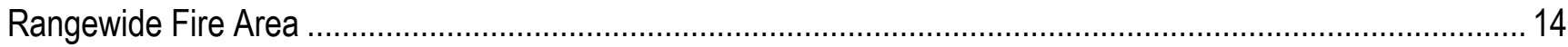

Western Regional Fire Area and Other Fire Regime Characteristics ............................................................. 17

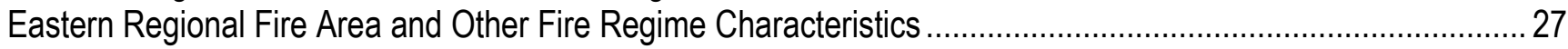

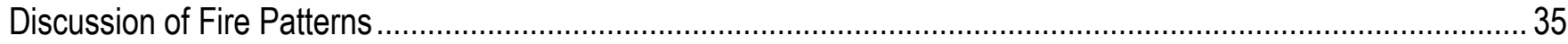

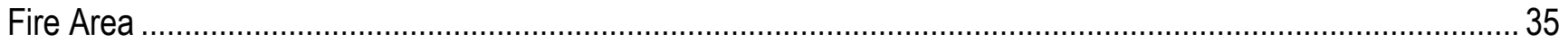

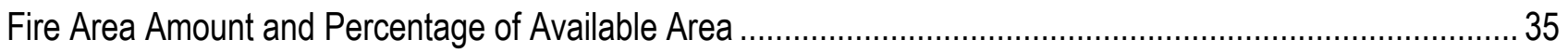

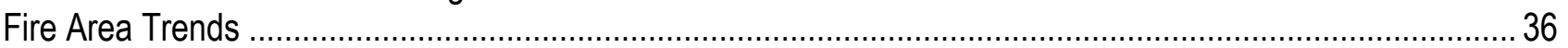

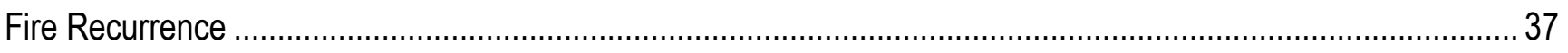

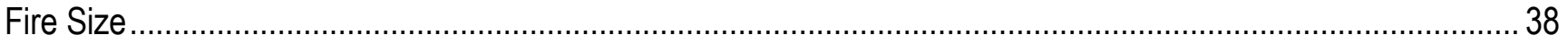

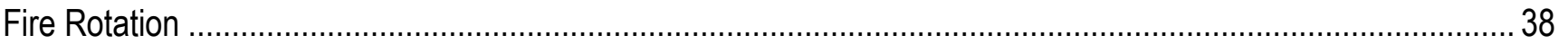

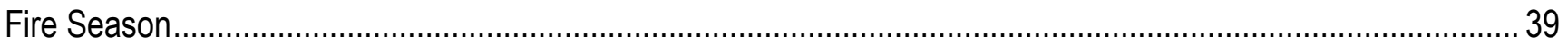

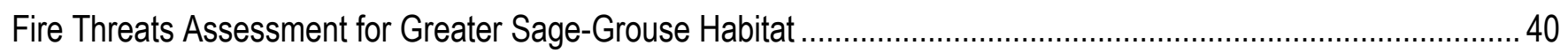

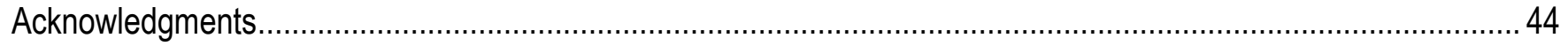

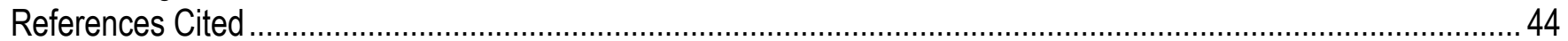

Appendix 1. Crosswalk of Greater Sage-Grouse Management Zones with Other Bioregional Classifications ........50

Appendix 2. Proportion of Land Ownership in the Greater Sage-Grouse Management Zones...............................51

Appendix 3. Soil Temperature and Moisture Regimes in the Study Area ........................................................ 52

Appendix 4. Aerial Extent of the Major Vegetation Types in the Four Western Management Zones and Their

Constituent LANDFIRE Biophysical Setting Types That Were Previously Identified as Capable of Supporting Sagebrush Vegetation and Providing Suitable Seasonal Habitat for Greater Sage-Grouse in the Greater SageGrouse Monitoring Framework

Appendix 5. Aerial Extent of the Major Vegetation Types in the Three Eastern Management Zones and Their Constituent LANDFIRE Biophysical Setting Types That Were Previously Identified as Capable of Supporting Sagebrush Vegetation and Providing Suitable Seasonal Habitat for Greater Sage-Grouse in the Greater SageGrouse Monitoring Framework

Appendix 6. Crosswalk of Soil Temperature and Moisture Regimes with Potential Resilience to Fire and Resistance to Annual Grass Invasion. 
Appendix 7. Proportions of Total Available Area Represented by Each Soil Temperature and Moisture Regime Class in Each Vegetation Type Rangewide and in the Eastern and Western Regions...........................................5 Appendix 8. Limitations of Fire Point Occurrence, Burn Severity, and Fire Perimeter Data.................................... 59 Appendix 9. Annual Precipitation Means (in millimeters per year) over the Long Term (1895-2013) and in the Years

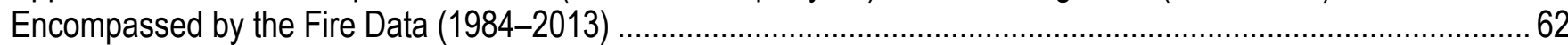
Appendix 10. Annual Precipitation Means (mm/yr) During Each of the 30 Years of the Study (1984-2013) Compared with the Previous 117 Years (1895-2012)

Appendix 11. Proportion of Fire Area Represented by Each Soil Temperature and Moisture Regime Class in Each Vegetation Type Rangewide.

Appendix 12. Proportion of Fire Area Represented by Each Soil Temperature and Moisture Regime Class in Each Vegetation Type in Each Greater Sage-Grouse Management Zone in the Western Region

Appendix 13. Proportion of Fire Area Represented by Each Soil Temperature and Moisture Regime Class in Each Vegetation Type in Each Greater Sage-Grouse Management Zone in the Eastern Region

\section{Figures}

Figure 1. Study area showing boundaries of each of the seven greater sage-grouse management zones (based on Stiver and others, 2006) that were a primary strata for analyses in this study. 5

Figure 2. Vegetation types that were a primary strata for analyses in this study ............................................... 9

Figure 3. Polygons of all fires used in this study overlaid to create recurrence classes ...................................... 15

Figure 4. Fire area for each year 1984-2013 within each major vegetation type throughout the range of the greater sage-grouse

Figure 5. Fire area for each year 1984-2013 within major vegetation types and the four management zones in the western region of the greater sage-grouse range

Figure 6. Cumulative fire area as a function of fire size in the four management zones in the western region of the greater sage-grouse range.

Figure 7. Cumulative fire area as a function of fire size in the western and eastern regions of the greater sage-grouse range

Figure 8. Fire size at the 25th, 50th, and 75th percentiles of the cumulative fire area distribution for each year 1984-2013 in the western region of the greater sage-grouse range

Figure 9. Fire season length for each year 1984-2013 in the four management zones in the western region of the greater sage-grouse range.

Figure 10. Fire area for each year 1984-2013 within major vegetation types and the three management zones in the eastern region of the greater sage-grouse range.

Figure 11. Cumulative fire area as a function of fire size in the three management zones in the eastern region of the greater sage-grouse range.

Figure 12. Fire size at the 25th, 50th, and 75th percentiles of the cumulative fire area distribution for each year 1984-2013 in the eastern region of the greater sage-grouse range

Figure 13. Fire season length for each year 1984-2013 in the three management zones in the eastern region of the greater sage-grouse range. 


\section{Tables}

Table 1. Aerial extent of the major vegetation types within the study area and their constituent LANDFIRE biophysical setting types that were previously identified as capable of supporting sagebrush vegetation and providing suitable seasonal habitat for greater sage-grouse in the Greater Sage-Grouse Monitoring Framework .... 7

Table 2. Fire area and percentage of fire area for each vegetation type rangewide (1984-2013) 14

Table 3. Fire area, percentage of fire area, and percentage of available area for each vegetation type in the management zones of the western region of the greater sage-grouse range (1984-2013).

Table 4. Fire recurrence area among fire recurrence classes within each vegetation type and management zone in the western range of the greater sage-grouse (1984-2013) .....

Table 5. Fire rotation (years) in each vegetation type and management zone in the western range of the greater sage-grouse (1984-2013)

Table 6. Fire season beginning (day of year), ending (day of year), and length (days) in each management zone in the western range of the greater sage-grouse (1984-2013)

Table 7. Fire area, percentage of total fire area, and percentage of available area for each vegetation type in the management zones of the eastern region of the greater sage grouse range (1984-2013)

Table 8. Fire recurrence area among fire recurrence classes in each vegetation type and management zone in the eastern region of the greater sage-grouse (1984-2013)

Table 9. Fire rotation (years) in each vegetation type and management zone in the eastern region of the greater sage grouse (1984-2013).

Table 10. Fire season variables (mean values) in each management zone in the eastern range of the greater sage grouse (1984-2013)

Table 11. Fire threats assessment on a scale from low to high (0-4) within nine regime categories 


\section{Conversion Factors}

International System of Units to Inch/Pound

\begin{tabular}{lll}
\hline \multicolumn{1}{c}{ Multiply } & By & \multicolumn{1}{c}{ To obtain } \\
\hline meter $(\mathrm{m})$ & Length & \\
kilometer $(\mathrm{km})$ & 3.281 & foot $(\mathrm{ft})$ \\
\hline & 0.6214 & mile $(\mathrm{mi})$ \\
\hline hectare (ha) & Area & \\
square hectometer $\left(\mathrm{hm}^{2}\right)$ & 2.471 & acre \\
hectare (ha) & 2.471 & acre \\
square hectometer $\left(\mathrm{hm}^{2}\right)$ & 0.003861 & square mile $\left(\mathrm{mi}^{2}\right)$ \\
\hline & 0.3861 & square mile $\left(\mathrm{mi}^{2}\right)$ \\
\hline millimeter per year $(\mathrm{mm} / \mathrm{yr})$ & Precipitation rate & \\
\hline
\end{tabular}

\section{Datum}

Horizontal coordinate information is referenced to the North American Datum of 1983 (NAD 83). 


\title{
Fire Patterns in the Range of the Greater Sage-Grouse, 1984-2013-Implications for Conservation and Management
}

\author{
By Matthew L. Brooks, John R. Matchett, Douglas J. Shinneman, and Peter S. Coates
}

\begin{abstract}
Fire ranks among the top three threats to the greater sage-grouse (Centrocercus urophasianus) throughout its range, and among the top two threats in the western part of its range. The national research strategy for this species and the recent U.S. Department of the Interior Secretarial Order 3336 call for science-based threats assessment of fire to inform conservation planning and fire management efforts. The cornerstone of such assessments is a clear understanding of where fires are occurring and what aspects of fire regimes may be shifting outside of their historical range of variation. This report fulfills this need by describing patterns of fire area, fire size, fire rotation, and fire season length and timing from 1984 to 2013 across the range of the greater sage-grouse. This information need is further addressed by evaluating the ecological and management implications of these fire patterns. Analyses are stratified by major vegetation types and the seven greater sage-grouse management zones, delineated regionally as four western and three eastern management zones. Soil temperature and moisture indicators of resilience to fire and resistance to cheatgrass invasion, and the potential for establishment of a grass/fire cycle, are used as unifying concepts in developing fire threat assessments for each analysis strata.

The results indicate that fire threats are higher in the four western than in the three eastern management zones. Among the four western management zones, the Snake River Plain and the Columbia Basin ranked somewhat higher than the Southern Great Basin and Northern Great Basin in terms of fire effects on sage-grouse habitat. These results support the previous high ranking of fire as a threat to the greater sage-grouse in the western region. In contrast, considering the low rankings for fire threats in the eastern region, it may be useful to reconsider the relative importance of wildfire as a threat to greater sage-grouse in those three management zones.
\end{abstract}




\section{Introduction}

\section{Study Purpose}

The greater sage-grouse (Centrocercus urophasianus) was initially considered for listing by the U.S. Fish and Wildlife Service in 2005 (U.S. Fish and Wildlife Service, 2005). Although listing was determined not to be warranted at that time, the decision document acknowledged that fire posed a significant threat. Wildland fire (hereinafter referred to as fire) was ranked third only to invasive species and human infrastructure among the greatest threats across its range, and second in the western part of its range (U.S. Fish and Wildlife Service, 2005). The subsequent 2010 decision concluded that listing the greater sage-grouse was warranted based on a similar threats analysis, but emphasized that most threats including fire had become increasingly more prominent (U.S. Fish and Wildlife Service, 2010).

The greater sage-grouse is currently listed as a candidate species throughout its range, meaning that its listing as Threatened or Endangered under the Endangered Species Act of 1973 is warranted, but a final decision is currently precluded by higher priority species (U.S. Fish and Wildlife Service, 2010). A lawsuit in 2011 challenged the timeframe for a listing decision on the greater sage-grouse and the associated court decision established a deadline of September 30, 2015, for a final decision on whether or not to list this species. In preparation for this listing decision, the U.S. Fish and Wildlife Service has been compiling and synthesizing the best current information to update their state-of-science understanding of the ecology, threats, and potential recovery actions for this species.

Chief among the information needed for the current listing decision is an updated understanding of the threats posed by fire. The national research strategy for the greater sage-grouse specifically calls for information to "assess fire history and fire-recovery rates in a way that informs planning efforts and deployment of resources for future fire events" (Hanser and Manier, 2013, p. 7). In January 2015, a U.S. Department of the Interior Secretarial Order was issued on rangeland fire prevention, management, and restoration that calls for a "science-based strategy to reduce the threat of large-scale rangeland fire to habitat for the greater sage-grouse and the sagebrush-steppe ecosystems" (U.S. Department of the Interior Secretarial Order 3336, 2015a, Section 6a). Soon following that Executive Order was a report released in May 2015 titled, "An Integrated Rangeland Fire Management Strategy", with the purpose "... to improve the efficiency and efficacy of actions to address rangeland fire, to better prevent and suppress rangeland fire, and improve efforts to restore fire-impacted landscapes" (U.S. Department of the Interior, 2015b). Science-based threats assessments are integral to efficient and effective fire management, and the cornerstone of these assessments is a clear understanding of where fires are occurring and what aspects of fire regimes may be shifting outside of their historical range of variation.

The purpose of the current report is to provide a scientific assessment of recent spatio-temporal patterns in the amount of fire area and other fire regime characteristics during the most recent 30-year period with comprehensive fire data (1984-2013), and to evaluate implications of these findings for conservation and management of the greater sage-grouse in wildland areas across the species' range. A complementary assessment using a subset of the same fire dataset was published in parallel with this report, and is focused on fire and climatic effects on sage-grouse population growth derived from 30 years of lek-count data in the Great Basin portion of the species' range (Coates and others, 2015). 


\section{Background}

The greater sage-grouse occurs in the cold desert ecoregion of Western North America (Schroeder and others, 2004). It is considered a sagebrush (Artemisia spp.) obligate species (Connelly and others, 2004), because it depends on sagebrush plants to provide most of its life-history needs including winter forage, nesting sites, and predator avoidance cover (Rowland and others, 2006; Knick and Connelly, 2011). Most sagebrush species such as big sagebrush (Artemisia tridentata), black sagebrush (Artemisia nova), and low sagebrush (Artemisia arbuscula) lack post-fire re-sprouting capabilities and have poor seed dispersal rates, resulting in high mortality and slow recovery following fire (Bunting and others, 1987; Baker, 2009). Two notable exceptions are silver sagebrush (Artemisia cana) and threetip sagebrush (Artemisia tripartita), which survive fire by vigorous resprouting from roots and rhizomes and can therefore tolerate periodic fire (White and Currie, 1983). The fire-intolerant sagebrush species are much more widespread and abundant than the fire-tolerant species, thus fire is generally considered to be a threat to sagebrush ecosystems and habitat quality for the greater sagegrouse.

Some studies have identified direct relationships between sage-grouse and fire, but have been limited to local sites (Connelly and others, 2000), movements and habitat associations (Fischer and others, 1996, 1997; Nelle and others, 2000; Rhodes and others, 2010), relatively short time frames $(<10$ year) (Blomberg and others, 2012), habitat suitability (Davis and Crawford, 2015), or relied primarily on simulations (Pedersen and others, 2003). A recent published report clearly demonstrates adverse long-term effects of wildfire on sage-grouse population growth rate across the Great Basin (Coates and others, 2015).

Although large and severe fires historically occurred in many sagebrush ecosystems, they were typically infrequent, especially in the warmer-drier, fuel-limited sagebrush community types. Mean fire return intervals may have ranged from decades in colder-moister sagebrush ecosystems (Miller and Heyerdahl, 2008) to hundreds of years in hotter-drier sagebrush ecosystems (Bukowski and Baker, 2013), allowing for recovery and persistence of sagebrush communities adapted to those conditions. However, during recent decades, fire probability and occurrence have increased across large portions of the cold desert ecoregion of Western United States (Whisenant, 1989; Knick and Rotenberrry, 1997; Chambers, 2008; Miller and others, 2011; Baker, 2013; Balch and others, 2013), hindering recovery of sagebrush and threatening sage-grouse habitat.

Increased prevalence of fire in the sagebrush ecosystem is strongly associated with the influence of non-native invasive annual grasses, especially cheatgrass (Bromus tectorum) in the more arid regions of the western part of the greater sage-grouse range. Cheatgrass can fill the interspaces between native perennials and facilitate fire spread where it would not otherwise occur, especially in more arid regions where native plant productivity is low (Whisenant, 1989). This is a particular concern for more arid sagebrush shrublands, dominated by Wyoming big sagebrush (Artemisia tridentata ssp. wyomensis) and basin big sagebrush (Artemisia tridentata ssp. tridentata) (Brooks and others, in press). These landscapes often have a minimal perennial grass component and low resilience (that is, ability to recover) of sagebrush vegetation following fire and low resistance to cheatgrass invasion (Chambers and others, 2014a, 2014b; Brooks and others, in press). These conditions can result in greatly reduced fire-free intervals and prevent reestablishment of the native sagebrush community. This dynamic leads to a self-perpetuating "grass/fire cycle" (D'Antonio and Vitousek, 1992) that favors the dominance and spread of invasive annual grasses, which in turn facilitate more frequent fire (Brooks and others, 2004; Brooks, 2008). 
Decreased prevalence of fire also can pose a threat to the greater sage-grouse in portions of its range, especially in Mountain Big Sagebrush (Artemisia tridentata ssp. vaseyana) communities, which are more productive and include more perennial grasses than in arid regions. These landscapes have moderate to high resilience of sagebrush vegetation following fire and resistance to cheatgrass invasion (Chambers and others, 2014a, 2014b). Reduction of fuels caused by livestock grazing and fire suppression activities are thought to have increased fire return intervals to the point where conifer species (especially juniper and pinyon) can establish and eventually outcompete sagebrush, leading to a reduction of perennial grasses and forbs (Miller and Tausch, 2001). This reduction in habitat quality for the greater sage-grouse (Miller and Rose, 1999; Miller and Heyerdahl, 2008) has led to avoidance of areas with trees (Casazza and others, 2011) and declines in population persistence (Baruch-Mordo and others, 2013). Conifer encroachment was ranked tenth among threats across the range of the species, and fourth in the western part of its range in the 2005 listing decision (U.S. Fish and Wildlife Service, 2005).

Although fire area generally is reported to have increased during the past few decades in the cold deserts of North America, these patterns are often characterized using broad-scale, regional assessments integrated across diverse ecoregions and vegetation types (for example, Littell and others, 2009).

Research specific to fire patterns in sagebrush ecosystems have included analysis of area burned relative to cheatgrass dominance in a large portion of the Great Basin (Balch and others, 2013), and assessments of spatial and temporal trends in fire area, fire size, and fire frequency in floristic provinces across the sagebrush biome (Baker, 2011; Miller and others, 2011; Baker, 2013). To best inform conservation and management efforts for the greater sage-grouse, there is a need to more precisely analyze fire area and other fire regime characteristics in landscapes most relevant to this species. To facilitate the evaluation of habitat responses to these fire patterns and ultimately fire threats, they also should be evaluated specifically in landscapes that the greater sage-grouse occupies and at scales that match current understanding of the fire ecology of major vegetation types.

\section{Methods}

The primary objective of this study was to evaluate spatio-temporal patterns of fire in greater sage-grouse population areas throughout the species' range. Fire area was evaluated at rangewide, regional (western vs. eastern), and greater sage-grouse management zone scales. Fire size, fire recurrence, fire rotation, and fire season length and timing were evaluated at regional and management zones scales. All analyses were stratified by major sagebrush vegetation types. Fire threats analyses were based on the relative resilience to fire and resistance to cheatgrass invasion of these vegetation types, as inferred from their soil temperature and moisture regimes (Campbell, 2014) and the general fire ecology literature.

\section{Study Area}

The study area is defined as the greater sage-grouse population areas in the Western United States, spanning the current range of the species as defined by Schroeder and others (2004) (fig. 1). These population areas include some urban, agricultural, and other developed lands that are typically under private or municipal ownership, generally do not constitute habitat for the greater sage-grouse, and are poorly represented in the fire database used in this study. Thus, developed areas and unburnable areas (for example, open water) were excluded from the study area and not analyzed. We refer to the remaining $77,308,081$ ha $\left(298,487 \mathrm{mi}^{2}\right)$ area which was the focus of this study as "sage-grouse wildland area." 


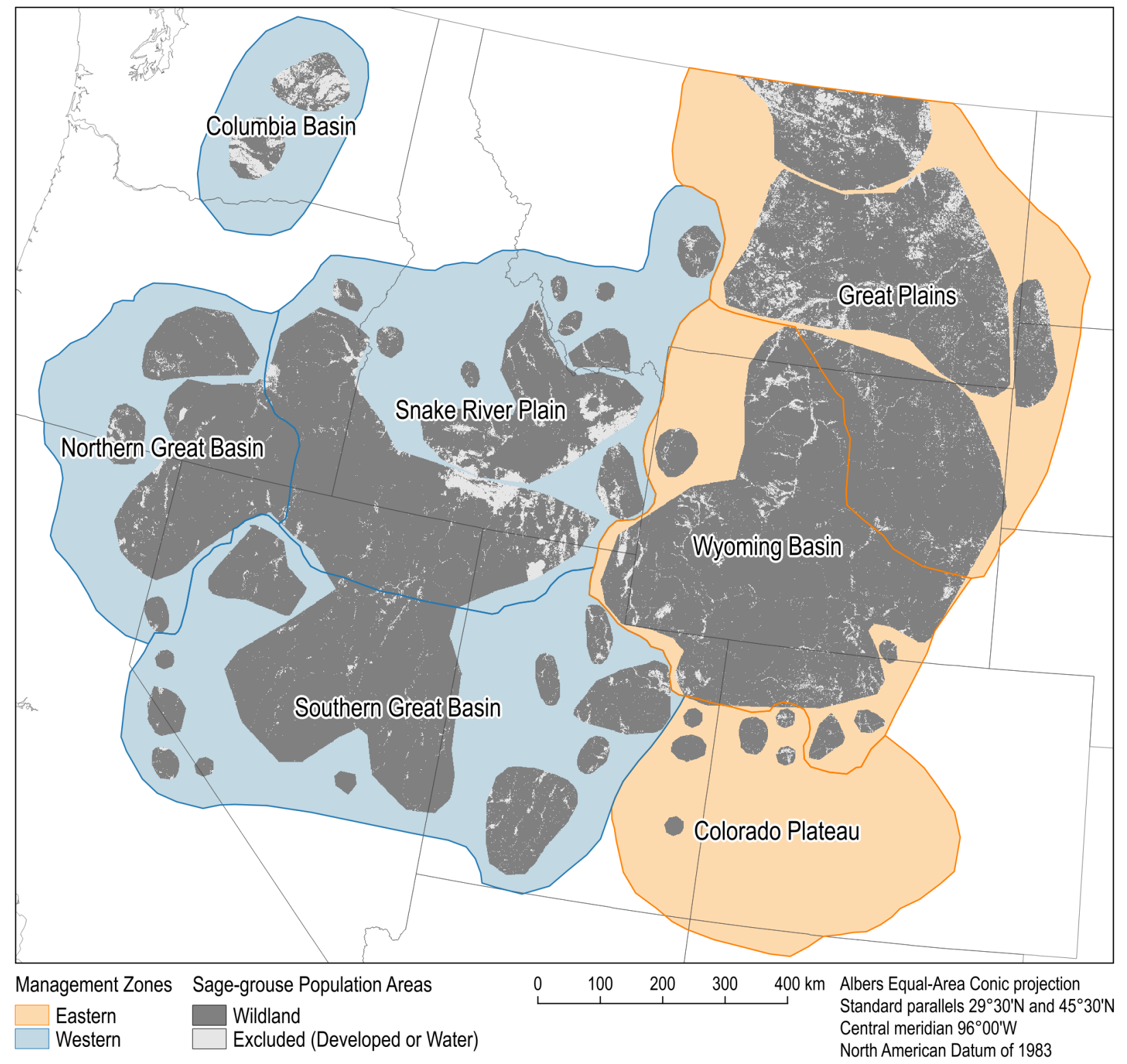

Figure 1. Study area showing boundaries of each of the seven greater sage-grouse management zones (based on Stiver and others, 2006) that were a primary strata for analyses in this study. The greater sage-grouse population areas also are shown which represent the geographic extent of landscapes include in the analyses. 


\section{Greater Sage-Grouse Management Zones}

The study area was partitioned into the seven management zones (fig. 1) identified by the Western Association of Fish and Wildlife Agencies, Conservation Strategy for Greater Sage-Grouse (Stiver and others, 2006). Each of the seven greater sage-grouse management zones correspond to a major floristic province (Miller and Eddleman, 2001) and EPA Level III ecoregion(s) (Wilken and others, 2011) (appendix 1), and the constituent vegetation in each management zone is expected to respond similarly to environmental factors and management actions. The proportion of lands under Federal, State, and local governmental jurisdiction varied widely among these management zones, with government lands covering equal to or greater than $75 \%$ of the Southern Great Basin, Northern Great Basin, Snake River Plain, and Colorado Plateau management zones, but encompassing less than $50 \%$ of the Great Plains and Columbia Basin management zones (appendix 2).

\section{Western and Eastern Regions}

The four western management zones were distinguished from the three eastern management zones (fig. 1) in the listing decisions (U.S. Fish and Wildlife Service, 2005, 2010). Their primary ecological distinction is based on the predominance of Xeric soil moisture regimes and winterdominated rainfall in the West, versus Ustic soil moisture regimes and summer-dominated rainfall in the East (appendix 3). This difference in rainfall seasonality can significantly affect landscape resilience to fire and resistance to cheatgrass (Chambers and others, 2014a, 2014b). Thus, in addition to the seven management zones, fire patterns also were analyzed and compared between the western and eastern regions, due to their potential to support substantially different fire regimes and fire effects.

\section{Vegetation Types}

We analyzed fire patterns among seven major vegetation types in the study area (table 1, fig. 2), each based on an amalgam of LANDFIRE biophysical settings (Rollins, 2009). LANDFIRE biophysical settings are derived in part using the same 30-m resolution Landsat satellite imagery also used to generate the fire data in this study (see section, "Sources of Fire Data"), which facilitated the spatial intersection of the data layers without a need for resampling. Biophysical settings represent potential vegetation based on the current biophysical environment and an approximation of the historical disturbance regime prior to Euro-American settlement (Rollins, 2009), essentially approximating the vegetation that might be present if disturbance regimes had not been altered post-settlement. We chose not to evaluate fire patterns among current vegetation types, such as those represented by the LANDFIRE existing vegetation type product. Current vegetation is the result of both the conditions represented by potential vegetation and the various ways that disturbance regimes have been altered since Euro-American settlement, including the influences of livestock grazing, plant invasions, anthropogenic ignitions, and altered fire regimes. Thus, the recent 30-year patterns of fire that is the focus of this study could have resulted in, or been a product of, patterns of current vegetation. Using potential vegetation avoided these cause-and-effect confounders and allowed us to more easily interpret recent patterns of fire among the vegetation types. 
Table 1. Aerial extent of the major vegetation types in the study area and their constituent LANDFIRE biophysical setting types that were previously identified as capable of supporting sagebrush vegetation and providing suitable seasonal habitat for greater sage-grouse in the Greater Sage-Grouse Monitoring Framework.

[From Interagency Greater Sage-Grouse Disturbance and Monitoring Subteam (2014, table 4). The first two vegetation types are predominantly sagebrush, whereas the latter four are pre-dominantly other plant taxa. All six differ in terms of floristics, fire regimes, and as potential habitat for the greater sage-grouse. The Non-Sagebrush type does not contain any sagebrush species as a potential dominant in the constituent biophysical settings descriptions and were not previously identified as supporting sagebrush vegetation or greater sage-grouse habitat. Dominant Artemisia spp: Artemisia species listed as a dominant in the biophysical settings descriptions of in the mapping zones used in the current study]

\begin{tabular}{|c|c|c|}
\hline Biophysical setting & $\begin{array}{c}\text { Area } \\
\text { hectares) }\end{array}$ & Dominant Artemisia spp \\
\hline \multicolumn{3}{|c|}{ Big Sagebrush } \\
\hline Inter-Mountain Basins Big Sagebrush Steppe & $10,468,051$ & $\begin{array}{l}\text { A. tridentata } \text { ssp. wyomensis } \\
\text { A. tridentata } \text { ssp. tridentata }\end{array}$ \\
\hline $\begin{array}{l}\text { Inter-Mountain Basins Big Sagebrush Shrubland - Wyoming } \\
\text { Big Sagebrush }\end{array}$ & $7,896,148$ & A. tridentata ssp. wyomensis \\
\hline Inter-Mountain Basins Montane Sagebrush Steppe & $6,748,739$ & $\begin{array}{l}\text { A. tridentata ssp. vaseyana } \\
\text { A. tripartita ssp. tripartita }\end{array}$ \\
\hline Inter-Mountain Basins Big Sagebrush Shrubland & $5,141,354$ & $\begin{array}{l}\text { A. tridentata ssp. wyomensis } \\
\text { A. tridentata ssp. tridentata }\end{array}$ \\
\hline $\begin{array}{l}\text { Inter-Mountain Basins Big Sagebrush Shrubland - Basin Big } \\
\text { Sagebrush }\end{array}$ & 634,153 & A. tridentata ssp. tridentata \\
\hline $\begin{array}{l}\text { Inter-Mountain Basins Montane Sagebrush Steppe - Mountain } \\
\text { Big Sagebrush }\end{array}$ & 871,684 & A. tridentata ssp. vaseyana \\
\hline \multicolumn{3}{|c|}{ Black/Low Sagebrush } \\
\hline Great Basin Xeric Mixed Sagebrush Shrubland & $6,984,654$ & $\begin{array}{l}\text { A. nova } \\
\text { A. bigelovii }\end{array}$ \\
\hline Columbia Plateau Low Sagebrush Steppe & 246,249 & $\begin{array}{l}\text { A. arbuscula } \\
\text { A. arbuscula ssp. longiloba }\end{array}$ \\
\hline $\begin{array}{l}\text { Inter-Mountain Basins Montane Sagebrush Steppe - Low } \\
\text { Sagebrush }\end{array}$ & 147,456 & A. nova \\
\hline Colorado Plateau Mixed Low Sagebrush Shrubland & 73,503 & $\begin{array}{l}\text { A. arbuscula } \\
\text { A. nova } \\
\text { A. cana }\end{array}$ \\
\hline Wyoming Basins Dwarf Sagebrush Shrubland and Steppe & 4,282 & $\begin{array}{l}\text { A. nova } \\
\text { A. arbuscula } \\
\text { A. pedatifida } \\
\text { A. tripartita }\end{array}$ \\
\hline \multicolumn{3}{|c|}{ Desert Mixed Shrub } \\
\hline Inter-Mountain Basins Mixed Salt Desert Scrub & $2,698,410$ & $\begin{array}{l}\text { A. tridentata ssp. wyomensis } \\
\text { A. tridentata ssp. tridentata }\end{array}$ \\
\hline Columbia Plateau Scabland Shrubland & 194,873 & A. rigida \\
\hline Inter-Mountain Basins Semi-Desert Shrub-Steppe & 95,500 & $\begin{array}{l}\text { A. tridentata ssp. wyomensis } \\
\text { A. tridentata ssp. tridentata }\end{array}$ \\
\hline \multicolumn{3}{|c|}{ Floodplain } \\
\hline Western Great Plains Floodplain Systems & 893,044 & A. cana ssp. cana \\
\hline
\end{tabular}




\begin{tabular}{|c|c|c|}
\hline Biophysical setting & $\begin{array}{c}\text { Area } \\
\text { hectares) }\end{array}$ & Dominant Artemisia spp \\
\hline \multicolumn{3}{|c|}{ Grassland } \\
\hline Northwestern Great Plains Mixed Grass Prairie & $12,785,292$ & A. cana ssp. cana \\
\hline Northwestern Great Plains Shrubland & $1,004,669$ & A. cana ssp. cana \\
\hline Columbia Plateau Steppe and Grassland & 809,650 & A. spp. \\
\hline Western Great Plains Sand Prairie & 194,122 & A. cana ssp. cana \\
\hline \multicolumn{3}{|c|}{ Mountain Brush } \\
\hline $\begin{array}{l}\text { Inter-Mountain Basins Curl-leaf Mountain Mahogany Woodland } \\
\text { and Shrubland }\end{array}$ & 517,666 & A. tridentata ssp. vaseyana \\
\hline Rocky Mountain Gambel Oak-Mixed Montane Shrubland & 401,983 & A. tridentata ssp. vaseyana \\
\hline Rocky Mountain Lower Montane-Foothill Shrubland & 140,959 & A. tridentata ssp. vaseyana \\
\hline \multicolumn{3}{|c|}{ Non-Sagebrush } \\
\hline remaining biophysical setting types combined $(n=117)$ & $18,356,248$ & none \\
\hline
\end{tabular}




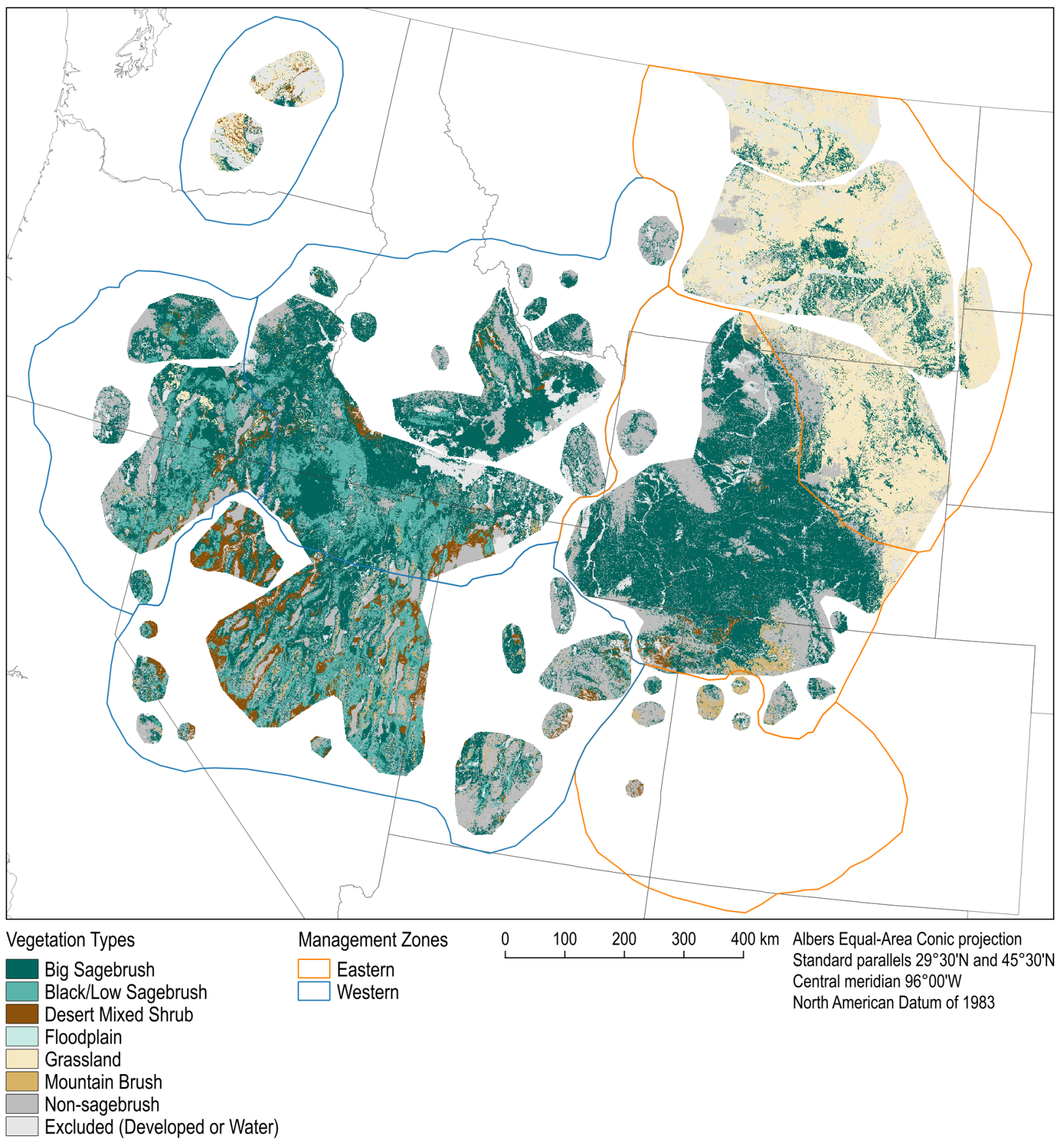

Figure 2. Vegetation types that were a primary strata for analyses in this study. Descriptions of LANDFIRE biophysical settings (Rollins, 2009) that comprised each vegetation type are listed in table 1. 
Each vegetation type we defined was comprised of multiple biophysical settings that were distinct from each other in terms of vegetation structure, dominant sagebrush species, and historical fire regimes according to LANDFIRE's descriptions. Each vegetation type also has distinct enough physiographic characteristics, which we felt were accurately differentiated by LANDFIRE's biophysical settings classification model. LANDFIRE did not attempt a formal accuracy assessment of the biophysical settings layer; however, their accuracy assessments of existing vegetation layers indicated difficulty distinguishing between sagebrush types having similar physiognomy. This latter point is the primary reason we did not further split the Big Sagebrush vegetation category into shrubland, steppe, montane, basin, and/or Wyoming big sagebrush types.

Two vegetation types (Big Sagebrush and Black/Low Sagebrush) are comprised mostly of sagebrush-dominated communities, whereas four (Desert Mixed Shrub, Floodplain, Grassland, and Mountain Brush) are characterized by mostly Non-Sagebrush dominated communities, but which have potential for at least one sagebrush species to be co-dominant (table 1). The Non-Sagebrush vegetation type included 117 biophysical settings that do not support sagebrush-containing communities.

The Big Sagebrush vegetation type comprised $41 \%$ of the total sage-grouse wildland area in this study (table 1), slightly more of which (55\%) occurred in the western region (appendix 4). Grassland comprised $19 \%$ of the total study area (table 1), with the vast majority $(95 \%)$ in the eastern region (appendix 5). Black/Low Sagebrush and Desert Mixed Shrub comprised 10\% and 4\% of the study area respectively (table 1), nearly all (92\% and 99\%, respectively) occurring in the western region (appendix 4). Floodplain and Mountain Brush each comprised 1\% of the study area (table 1), with virtually all for the former (99\%) in the eastern region (appendix 5) and slightly more $(52 \%)$ of the latter in the western region (appendix 4). Non-Sagebrush vegetation comprised $24 \%$ of the total study area (table 1 ), slightly more of which (59\%) was in the western region (appendix 4). Thus, the western region contained the majority of Black/Low Sagebrush and Desert Mixed Shrub vegetation, the eastern region contained most of the Grassland and Floodplain vegetation, whereas Big Sagebrush, Mountain Brush, and NonSagebrush were more evenly distributed between the two regions.

\section{Soil Temperature and Moisture Regimes as Indicators of Resilience/Resistance}

We used the seven soil temperature and moisture regime classes of Campbell (2014) (appendix 3) to help infer the relative resilience to fire and resistance to invasive annual grasses in each analysis stratum. In general, soil moisture is positively associated with resilience to fire and soil temperature is negatively associated with resistance to annual grasses (Chambers and others, 2007, 2014a, 2014b). More specifically, the hotter-drier, winter-rainfall dominated, Mesic/Aridic and Frigid/Aridic regimes are associated with lower resilience/resistance, whereas the Cryic, Frigid/Ustic, and Frigid/Xeric regimes are associated with higher resilience/resistance (appendix 6) (Chambers and others, 2014a, 2014b). Winter rainfall regimes (that is, Aridic) generally are negatively associated with resistance because non-native annual grasses are well adapted to Mediterranean climatic conditions (Bradford and Lauenroth, 2006; Bradley, 2009). In contrast, summer rainfall regimes (that is, Ustic) generally are positively associated with resistance because they facilitate growth of perennial grasses that help to competitively exclude non-native annual grasses. The raster layer of soil temperature and moisture regimes was created using 5-m pixel resolution, which we upscaled to 30-m resolution using a nearest neighbor approach in order to match the resolutions of the vegetation and fire layers. 
The majority of area in Big Sagebrush, Black/Low Sagebrush and Desert Mixed Shrub vegetation types is classified as Mesic/Aridic or Frigid/Aridic, and thus relatively low resilience and resistance, especially in the western region (appendix 7). In contrast, most of the Floodplain, Grassland, and Mountain Brush vegetation types are classified as Cryic, Frigid/Ustic, or Mesic/Ustic, and thus relatively high resilience/resistance.

\section{Sources of Fire Data}

Fire data produced by the Monitoring Trends in Burn Severity (MTBS) program (http://www.mtbs.gov/) were used as the basis for all analyses in this study, largely because of their mapping precision, accuracy, and consistent methodology across the study area (appendix 8). The MTBS program is focused on documenting fires equal to or greater than 405 ha $(1,000$ acres) in the Western United States. Although small fire $(<405 \mathrm{ha})$ data were available from point occurrence datasets, these data were not used because of known errors and inconsistencies. For example, the relative level of completeness of point fire occurrence data varies widely across different types of public and private land ownership (appendix 8), which would skew results across the management zones used in this study (appendix 2). In addition, point data are not amenable to spatial analyses that parse the landscape by vegetation or soil temperature and moisture regime (appendix 8).

The MTBS fire perimeter data slightly over-represent area burned because they include unburned inclusions; however, they also under-represent overall burned area by not including smaller fires ( $<405 \mathrm{ha}$ ) (appendix 8). These smaller fires typically represent about $5 \%$ of the total area burned in a given area (Eidenshink and others, 2007), which is similar to estimates of small fire area not represented in the dataset used in the current study (appendix 8). The net result of not accounting for unburned inclusions and not using smaller fires is that the final estimates of fire area in this study are likely to be highly representative of actual burned area (appendix 8).

Utilizing only MTBS fires also is supported by their greater ecological relevance compared to smaller fires. Some of the most significant ecological impacts on sagebrush ecosystems may be associated with relatively large fires. For instance, a recent study within the boundaries of the hydrographic Great Basin estimated adverse effects on greater sage-grouse population growth rates when fires are adjacent to lek sites and fire sizes reached more than 916 ha (2,265 acres) (Coates and others, 2015). Additionally, significant rates of soil erosion in sagebrush landscapes have been reported for most fires more than 4,047 ha (10,000 acres) and rarely for smaller fires (Matt Germino, U.S. Geological Survey, written commun., February 10, 2015).

The fire data we used from the MTBS program spanned the years 1984 through 2013. The beginning of this time interval represented the first year that a consistent form of Landsat satellite imagery at $30 \times 30 \mathrm{~m}$ resolution was available (Eidenshink and others, 2007). The last year represented the most recent in which completed data were available. 


\section{Analyses}

Fire Area.-We focused on fire area, rather than fire numbers, based on the premise that the amount of fire area is more relevant to the ecology and management of the greater sage-grouse. A given fire's area was based on the portion of its perimeter that intersected our study area, and was calculated by summing all pixels classified as unburned-to-low, low, moderate, high, increased greenness, and non-processed in the fire's thematic burn severity raster. We did not exclude unburned-to-low pixels from a fire's area because of biases in initial versus extended assessment fires (see appendix 8), and we included non-processed pixels (typically clouds or missing pixels in Landsat 7 scenes following the failure of its scan line corrector) in the total because MTBS analysts chose to include them within the fire's perimeter. These fire area pixels were then used to extract and summarize pixels from the sagebrush types and soil moisture and temperature regime rasters.

Trends in annual fire area were evaluated by summing the fire area within a given stratum, and then performing one-tailed tests for monotonic increasing trends using the non-parametric MannKendall statistic (Mann, 1945; Kendall, 1975). To display trends in annual fire area, we plotted the proportion of total area burned each year of the study period in each strata. Rangewide analyses included 8 strata ( 7 vegetation types plus all types combined), western regional analyses included 35 strata (6 vegetation types — because Floodplains were absent — plus all types, multiplied by 4 management zones plus all zones), and eastern regional analyses included 32 strata (7 vegetation types plus all types, multiplied by 3 management zones plus all zones). Given the large number of separate statistical tests, one might expect some significant trends to occur merely by chance. To control for this test multiplicity, we adjusted the p-values of individual tests to minimize the overall false discovery rate, which is the expected proportion of tests declared to be "significant" that are truly not significant. We used a conservative approach for false discovery rate $p$-value adjustment recommended by Benjamini and Yekutieli (2001) because some tests in the overall set are likely strongly correlated because some strata are aggregations of other strata. We present both the unadjusted and adjusted pvalues, thus bracketing our estimates of significance by the least and most conservative statistical approaches.

Fire Recurrence.-Fire recurrence is defined as the number of times that fire occurred in a specific area during 1984-2013. We created a fire recurrence raster layer by calculating the total number of times each pixel was within a fire area over this 30 -year period. The fire recurrence raster was then intersected with the vegetation and soil raster layers to calculate both the total and the percentage of fire area that burned one or more times in each vegetation type and soil temperature/moisture regime class.

Fire Size.-Fire size is the total burned and unburned area within the perimeter of a particular fire (Sugihara and others, 2006). Determining average fire size, as well as addressing the question of whether fires are getting bigger over time, is complicated by the highly non-normal distribution of fire sizes. This is because small fires are the most abundant, permitting a few large fires to greatly influence measures of central tendency. Statistical techniques (for example, log-transformation, trimmed means, quantile regression) can address some of these concerns; however, such calculations are further complicated by incomplete point data for smaller fires ( $<405$ ha; see appendix 8$)$. Alternatively, we characterized how the proportion of total fire area is distributed across fire sizes because the dataset of large fires we used likely encompasses all the area burned despite the exclusion of small fires. We developed cumulative distribution curves for a given stratum of interest by plotting the size of individual fires (ordered from smallest to largest) versus the cumulative proportion of total fire area. We evaluated directional shifts in these fire size-cumulative area curves over time by determining the fire sizes at the 25th, 50th, and 75th percentiles of the cumulative fire area distributions calculated for each of the 30 years of the study. We did this for the western management zones combined and the eastern 
management zones combined. We were not able to conduct this analysis separately for all seven management zones, because most had too many years with too few MTBS fires to create reasonable cumulative distribution curves. We tested for increasing trends of fire sizes at the 25th, 50th, and 75th percentiles using one-tailed Mann-Kendall trend tests and present $p$-values that are both unadjusted and adjusted (for false discovery rates).

Fire Rotation.-Fire rotation is defined as the time necessary to burn an area equal in size to a particular area of interest (Sugihara and others, 2006). Fire rotation was calculated within the various strata by taking the timespan of the dataset (30 years) and dividing it by the proportion of area that burned during that period (Agee, 1993). Because the 30-year study period is shorter than all fire rotation values calculated and reported in this study, our estimates of fire rotations are only considered to be estimates because they are based on recent fire trends only, and might differ if reliable fire data were available for longer periods. Moreover, these estimates are reflective of the climate patterns over a recent 30-year period and do not incorporate the likely influence of projected future climate change on wildfire. Insufficient data were available to estimate fire rotation for strata that either had 0 ha burned during the 30-year study period, or in the case of Black/Low Sagebrush and Mountain Brush in the Columbia Basin, the amount of available area was very small (appendix 4).

Fire Season Timing and Length.- Various definitions of fire season have been used for firerelated research (for example, Westerling and others, 2006; Jolly and others, 2015). Here we define the beginning of the fire season for a given year as the start date of the first large fire ( $\geq 405 \mathrm{ha})$ and the ending of the season as the start date of the last large fire. The actual end of a fire can be defined various ways that are somewhat subjective (for example date of containment or control), but only the start date is unambiguous and recorded in the metadata of the fire database we used. We calculated fire season length for each year by subtracting the beginning from the ending Julian dates. Years that had fewer than two fires equal to or greater than 405 ha resulted in a 0 -day fire season length. For each strata, mean annual fire season beginning and ending dates were calculated over the 30 -year period. We tested for increasing trends in fire season length using one-tailed Mann-Kendall trend tests and presented pvalues that were both unadjusted and adjusted for false discovery rates using the method of Benjamini and Yekutieli (2001). 


\section{Fire Pattern Results}

\section{Rangewide Fire Area}

Within all sage-grouse wildland areas, fire area totaled 10,270,949 ha $(25,380,067$ acres; 39,656 $\mathrm{mi}^{2}$ ) during the 30 -year study period (1984-2013), constituting $13 \%$ of the total available area (table 2 , fig. 3). The total wildland fire area presented in table 2 includes some area that burned more than once during the 30-year period, which we refer to as "recurrent fire" ( $\geq 2$ fires in the same place). Thus, although the total fire area represents $13 \%$ of the total available study area, only $11 \%$ of the available surface area burned during the 30 -year period.

Three-quarters of the total fire area rangewide occurred in Big Sagebrush (56\%), Black/Low Sagebrush (14\%), and Desert Mixed Shrub (4\%) (table 2). Although Desert Mixed Shrub represented the smallest amount of fire area, the percentage of available area burned was similar to that of Big Sagebrush and Black/Low Sagebrush: 14\% for the former, and 18\% and 19\%, respectively, for the other two. These three vegetation types were comprised of mostly low resilience/resistance landscapes characterized by Mesic/Aridic or Frigid/Aridic soil temperature and moisture regimes (appendix 11).

Non-Sagebrush represented $15 \%$ of the total fire area and burned at a rate of $9 \%$ of the total available area (table 2). Grassland was next at $10 \%$ of total fire area, and burned at a rate of $7 \%$ of the total available area. Floodplain and Mountain Brush represented less than $1 \%$ and $1 \%$ of the fire area, respectively, and were burning at a rate of $5 \%$ and $6 \%$ of the available area. These four vegetation types were comprised of high resilience/resistance landscapes of Cryic, Frigid/Ustic, and Frigid/Xeric soil temperature and moisture regimes (appendix 11).

All vegetation type displayed some degree of increasing annual fire area during the 30 -year study period (fig. 4). The differences among them were related to the strength and level of certainty in each trend. In two cases, Big Sagebrush and Black/Low Sagebrush, the p-values were relatively high even though there was an apparent increasing trend. This was likely due to relatively low 30-year sample size of the trends analyses. In another case, Desert Mixed Shrub, the p-value was relatively high and there was no obvious trend in annual fire area, so the lack of significance seemed to accurately reflect the absence of a trend. It is therefore important to evaluate both the pattern of the plots and the statistical p-values when evaluating trends.

Table 2. Fire area and percentage of fire area for each vegetation type rangewide (1984-2013).

\begin{tabular}{lrcc}
\hline \multicolumn{1}{c}{ Vegetation type } & $\begin{array}{c}\text { Fire area } \\
\text { (hectares) }\end{array}$ & $\begin{array}{c}\text { Percentage of } \\
\text { total fire area }\end{array}$ & $\begin{array}{c}\text { Percentage of } \\
\text { available area }\end{array}$ \\
\hline Big Sagebrush & $5,794,604$ & 56 & 18 \\
Black/Low Sagebrush & $1,409,797$ & 14 & 19 \\
Desert Mixed Shrub & 403,579 & 4 & 14 \\
Floodplain & 45,783 & $<1$ & 5 \\
Grassland & 988,726 & 10 & 7 \\
Mountain Brush & 62,821 & 1 & 6 \\
Non-Sagebrush & $1,565,639$ & 15 & 9 \\
Rangewide Total & $10,270,949$ & 100 & 13 \\
\hline
\end{tabular}




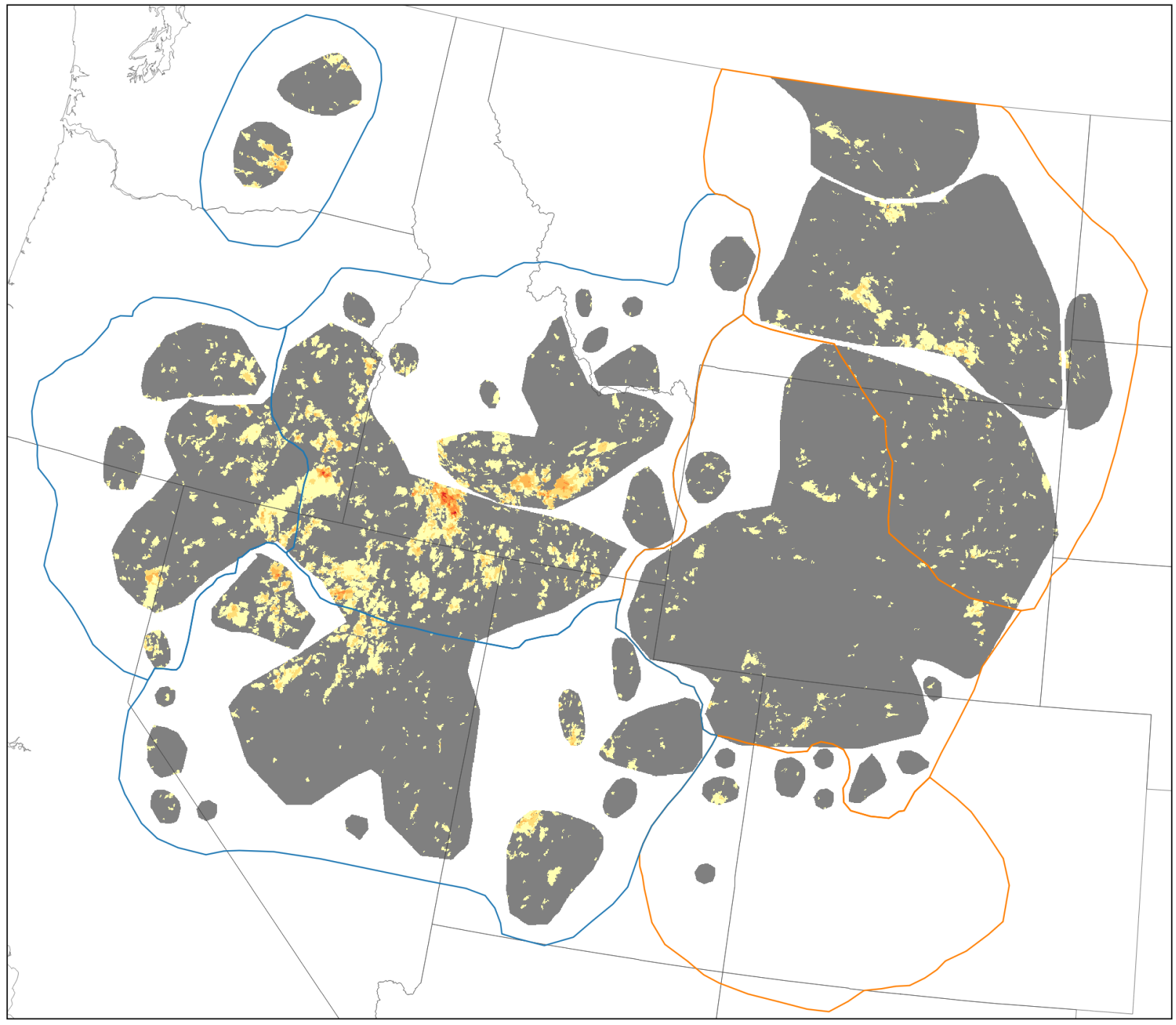

Times Burned Management Zones

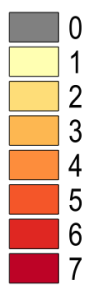

0

100

200

300

$400 \mathrm{~km}$ Albers Equal-Area Conic projection Standard parallels $29^{\circ} 30^{\prime} \mathrm{N}$ and $45^{\circ} 30^{\prime} \mathrm{N}$

Central meridian $96^{\circ} 00^{\prime} \mathrm{W}$

North American Datum of 1983

Figure 3. Polygons of all fires used in this study overlaid to create recurrence classes. Data were obtained from the Monitoring Trends in Burn Severity Program and are characterized by fires equal to or greater than 405 ha from 1984 to 2013. 


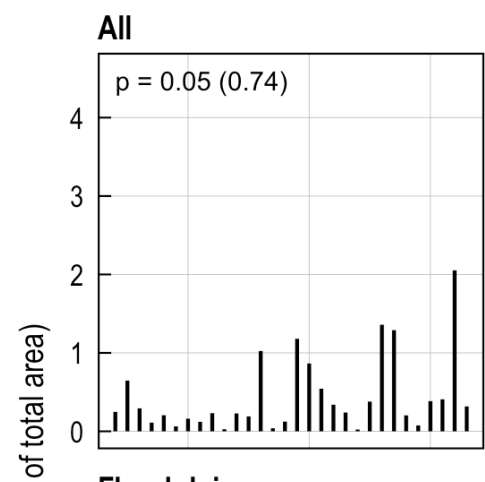

Big Sagebrush

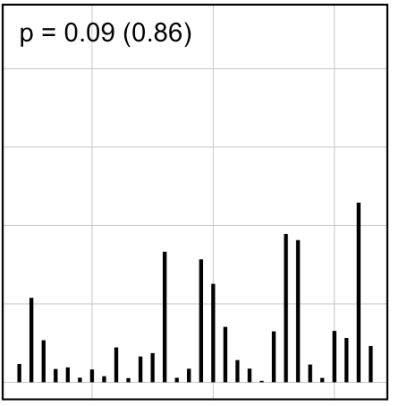

Grassland

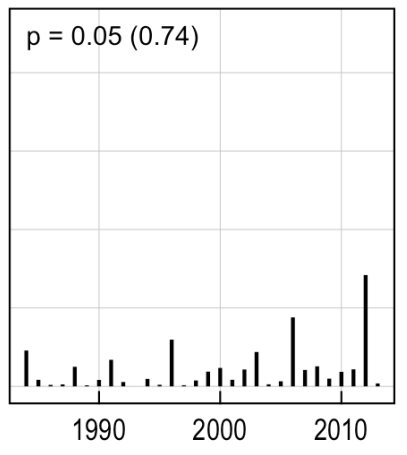

Black/Low Sagebrush

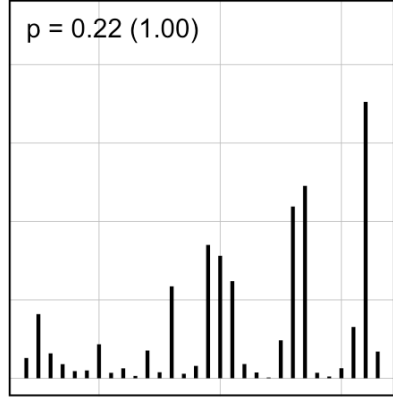

Mountain Brush

$p=0.05(0.74)$

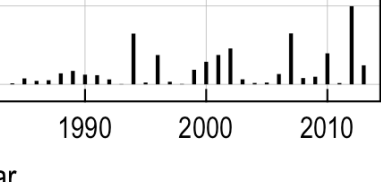

Desert Mixed Shrub

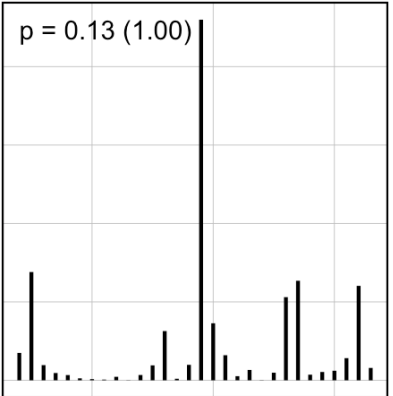

Non-sagebrush

$p=0.01(0.46)$

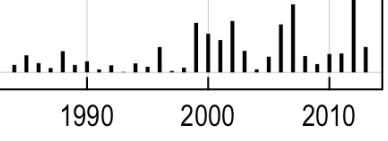

Figure 4. Fire area for each year 1984-2013 in each major vegetation type throughout the range of the greater sage-grouse. P-values are unadjusted and (adjusted for false discovery rate) to bracket the range of statistical confidence in the trends.

Non-Sagebrush vegetation had the highest level of certainty (unadjusted $\mathrm{p}=0.01$ ), followed by Floodplain ( $\mathrm{p}=0.03)$; Grassland, Mountain Brush, and all vegetation types combined $(\mathrm{p}=0.05)$; and Big Sagebrush $(p=0.09)$. Desert Mixed Shrub $(p=0.13)$ and Black/Low Sagebrush $(p=0.22)$ displayed unadjusted $\mathrm{p}$-values that were too large to be considered even low reliability indicators of increased fire area. Although as mentioned above, the high interannual variability in fire area for Black/Low Sagebrush may have statistically masked an otherwise apparently increasing trend. It should also be noted that $p$-values that were conservatively adjusted to control for false discovery rates associated with test multiplicity ( $\mathrm{n}=718$ tests) all displayed very low levels of certainty (adjusted $\mathrm{p}=0.50$ to $\mathrm{p}=1.00$ ). The high number of separate tests that were adjusted for and the lack of highly significant unadjusted pvalues are the likely reason for the high adjusted p-values. 


\section{Western Regional Fire Area and Other Fire Regime Characteristics}

Fire Area.-Within the sage-grouse wildland areas of the western region, fire area totaled $8,374,864$ ha $\left(20,701,824\right.$ acres; $\left.32,347 \mathrm{mi}^{2}\right)$ during the 30 -year study period (table 3, fig. 3), constituting $21 \%$ of the total available area in the western region $(39,649,711$ ha, appendix 4$)$. Accounting for recurrent fire, $17 \%$ of available surface area in the western region was burned one or more times. The total western region fire area (table 3$)$ represented the greatest majority ( $82 \%)$ of the total fire area across all sage-grouse wildland areas in this study, even though the western region constituted only one-half $(51 \%)$ of the total area in this study.

More than one-half $(60 \%, 5,029,815 \mathrm{ha})$ of the fire area in the western region was in the Snake River Plain management zone, and 88\% (4,459,799 ha) of that area was in Big Sagebrush and Black/Low Sagebrush vegetation types (table 3). The Southern Great Basin was next in prominence constituting 21\% (1,727,767 ha) of the fire area, with 63\% (1,093,305 ha) in Big Sagebrush and Black/Low Sagebrush, 16\% (268,897 ha) in Desert Mixed Shrub, and 20\% (345,611 ha) in NonSagebrush. The Northern Great Basin constituted 16\% (1,348,223 ha) of the fire area, with 78\% $(1,045,352 \mathrm{ha})$ in Big Sagebrush and Black/Low Sagebrush. The Columbia Basin rounded out the total fire area at 3\% (271,925 ha), with 57\% (153,400 ha) in Grassland and 26\% (71,150 ha) in Big Sagebrush.

Although the Columbia Basin represented the smallest amount of fire area, it burned at the same overall rate as the Snake River Plain (31\% of available area) (table 3). Big Sagebrush in the Columbia Plateau burned at a particularly high rate at $49 \%$ of available area, whereas Big Sagebrush in the Snake River plain burned at $38 \%$ of available area, and in each of the other two western management zones burned at $20 \%$ of available area.

Over three-quarters of the fire area in the western region occurred in areas of relatively low resilience/resistance (Mesic/Aridic or Frigid/Aridic) (appendix 12). These fire areas were mostly in Big Sagebrush, and to a lesser extent Black/Low Sagebrush, which together represented $80 \%$ of the total fire area (table 3). Non-Sagebrush vegetation accounted for $13 \%$ of the western region total (table 3 ) and was split evenly between the high and low ends of the resilience/resistance gradient (appendix 12), similar to what was observed in the rangewide fire summaries (appendix 11).

The strongest evidence of increasing fire area across the western region (fig. 5) was for NonSagebrush (unadjusted $\mathrm{p}=0.01)$, Mountain Brush $(\mathrm{p}=0.04)$, and all vegetation types combined $(\mathrm{p}=0.05)$ (fig. 5). These patterns were mostly driven by the Snake River Plain and Columbia Basin management zones, which also provided evidence of increasing trends with Big Sagebrush $(\mathrm{p}=0.05)$ and Desert Mixed Shrub $(p=0.09)$ in the former and Big Sagebrush $(p=0.04)$, Black/Low Sagebrush $(p=0.07)$, and Grassland $(\mathrm{p}=0.09)$ in the latter. The Southern Great Basin also displayed evidence of increasing trends in Non-Sagebrush $(p=0.01)$ and Mountain Brush $(p=0.07)$ vegetation types. The Northern Great Basin only showed weak evidence of increasing fire area in Non-Sagebrush $(\mathrm{p}=0.11)$. The remaining vegetation types in each management zones displayed unadjusted $\mathrm{p}$-values greater than 0.10 . All pvalues that were conservatively adjusted to control for false discovery rates associated with test multiplicity displayed very low levels of certainty (adjusted $p=0.50$ to $p=1.00$ ). Again, the very high number of separate tests that were adjusted for and the lack of highly significant unadjusted $\mathrm{p}=$ values are the likely reasons for the high adjusted p-values. 
Table 3. Fire area, percentage of fire area, and percentage of available area for each vegetation type in the management zones of the western region of the greater sage-grouse range (1984-2013).

\begin{tabular}{|c|c|c|c|}
\hline Vegetation Type & $\begin{array}{l}\text { Fire Area } \\
\text { (hectares) }\end{array}$ & $\begin{array}{c}\text { Percentage of } \\
\text { Fire Area }\end{array}$ & $\begin{array}{l}\text { Percentage of } \\
\text { Available Area }\end{array}$ \\
\hline \multicolumn{4}{|c|}{ Columbia Basin } \\
\hline Big Sagebrush & 71,150 & 26 & 49 \\
\hline Black/Low Sagebrush & 3 & 0 & 1 \\
\hline Desert Mixed Shrub & 20,937 & 8 & 20 \\
\hline Floodplain & 0 & 0 & 0 \\
\hline Grassland & 153,400 & 57 & 28 \\
\hline Mountain Brush & 3 & 0 & 11 \\
\hline Non-Sagebrush & 25,934 & 10 & 23 \\
\hline Columbia Basin Total & 271,426 & 100 & 31 \\
\hline \multicolumn{4}{|c|}{ Northern Great Basin } \\
\hline Big Sagebrush & 672,343 & 50 & 20 \\
\hline Black/Low Sagebrush & 373,009 & 28 & 22 \\
\hline Desert Mixed Shrub & 28,367 & 2 & 10 \\
\hline Floodplain & 0 & 0 & 0 \\
\hline Grassland & 21,230 & 2 & 11 \\
\hline Mountain Brush & 12,007 & 1 & 29 \\
\hline Non-Sagebrush & 240,216 & 18 & 11 \\
\hline Northern Great Basin Total & $1,347,172$ & 100 & 18 \\
\hline \multicolumn{4}{|c|}{ Snake River Plain } \\
\hline Big Sagebrush & $3,636,638$ & 72 & 38 \\
\hline Black/Low Sagebrush & 823,161 & 16 & 31 \\
\hline Desert Mixed Shrub & 83,767 & 2 & 17 \\
\hline Floodplain & 0 & 0 & 0 \\
\hline Grassland & 16,550 & 0 & 21 \\
\hline Mountain Brush & 19,978 & 0 & 15 \\
\hline Non-Sagebrush & 448,935 & 9 & 12 \\
\hline Snake River Plain Total & $5,029,028$ & 100 & 31 \\
\hline \multicolumn{4}{|c|}{ Southern Great Basin } \\
\hline Big Sagebrush & 880,825 & 51 & 20 \\
\hline Black/Low Sagebrush & 212,480 & 12 & 7 \\
\hline Desert Mixed Shrub & 268,897 & 16 & 14 \\
\hline Floodplain & 0 & 0 & 0 \\
\hline Grassland & 0 & 0 & 0 \\
\hline Mountain Brush & 19,424 & 1 & 5 \\
\hline Non-Sagebrush & 345,611 & 20 & 7 \\
\hline Southern Great Basin Total & $1,727,237$ & 100 & 12 \\
\hline \multicolumn{4}{|c|}{ Western Management Zones Combined } \\
\hline Big Sagebrush & $5,260,956$ & 63 & 30 \\
\hline Black/Low Sagebrush & $1,408,653$ & 17 & 19 \\
\hline Desert Mixed Shrub & 401,968 & 5 & 15 \\
\hline Floodplain & 0 & 0 & 0 \\
\hline Grassland & 191,180 & 2 & 23 \\
\hline Mountain Brush & 51,411 & 1 & 9 \\
\hline Non-Sagebrush & $1,060,696$ & 13 & 10 \\
\hline Western Management Zones & $8,374,864$ & 100 & 21 \\
\hline
\end{tabular}




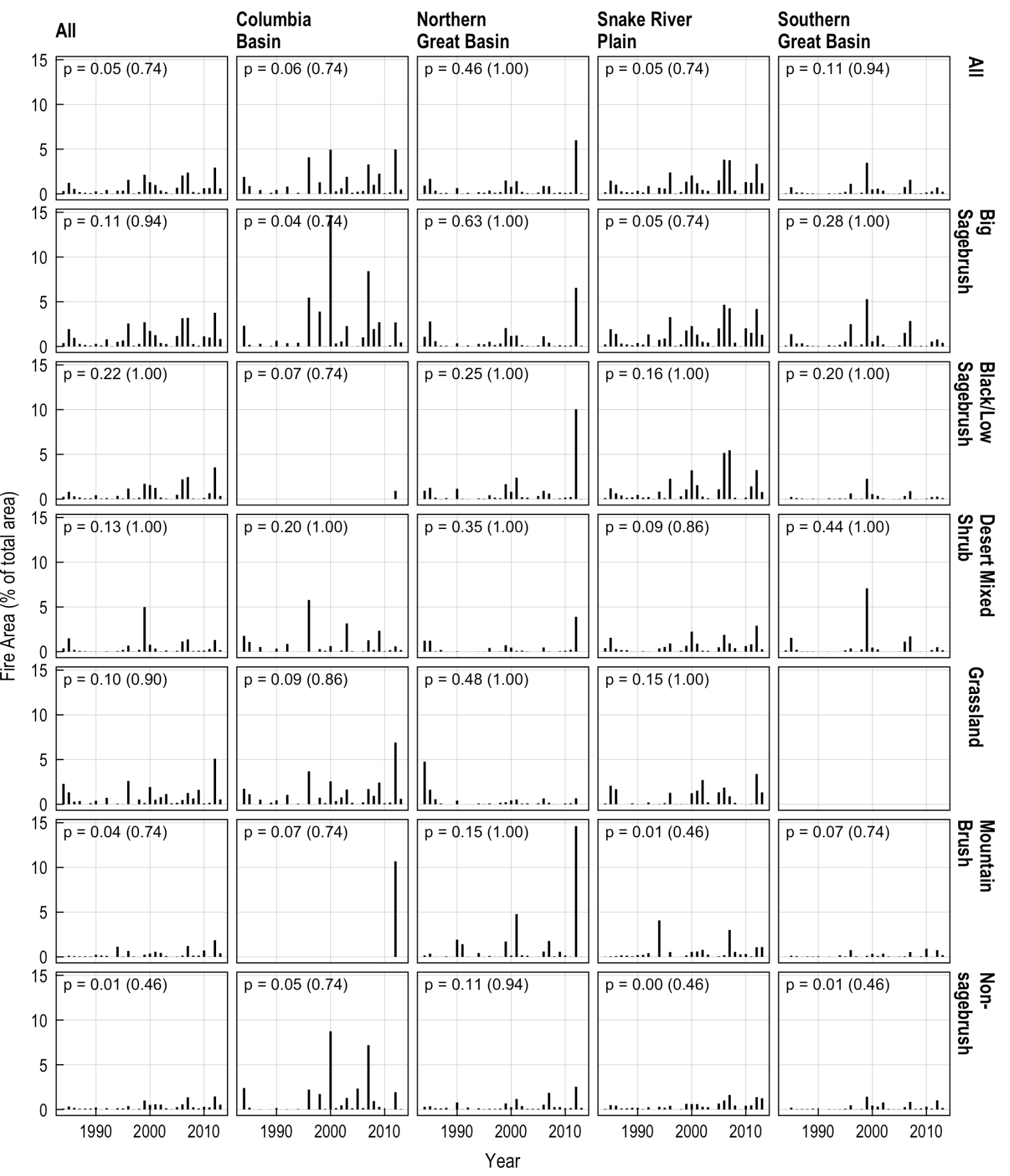

Figure 5. Fire area for each year 1984-2013 in major vegetation types and the four management zones in the western region of the greater sage-grouse range. P-values are unadjusted and (adjusted for false discovery rate) to bracket the range of statistical confidence in the trends. 
Fire Recurrence.--Recurrent fire area encompassed 1,412,673 ha, or $22 \%$ of the total fire area in the western region (table 4). The majority (65\%) of the recurrent fire area occurred in the Snake River Plain management zone (fig. 3). The Southern Great Basin (19\%), Northern Great Basin (11\%), and the Columbia Basin $(5 \%)$ round out the percentages of recurrent fire area in the western region.

Big Sagebrush encompassed 1,010,671 ha, or $72 \%$ of all recurrent fire area in the western region (table 4). Black/Low Sagebrush (13\%), Non-Sagebrush (8\%), Desert Mixed Shrub (5\%), Grassland $(2 \%)$, and Mountain Brush $(<1 \%)$ rounded out the percentages of recurrent fire area among western region vegetation types.

Although the smallest amount of recurrent fire area occurred in the Columbia Basin $(64,811 \mathrm{ha})$, it represented one-third (34\%) of the total fire area in that management zone (table 4). The vegetation types that were most responsible for the high proportion of recurrent fire were Non-Sagebrush (46\%), Big Sagebrush (45\%), and Desert Mixed Shrub (40\%).

Fire Size.- The size distributions of total fire area across fire sizes in the western region over the 30-year study period all differed somewhat among the four management zones (fig. 6). Fire sizes at the 25th, 50th, and 75th percentiles of cumulative fire area generally were highest for the Northern Great Basin at 4,211; 23,328; and 66,108 ha, respectively. The Snake River Plain was a second in fire size with 5,362; 17,436; and 59,826 ha fires at each of the three percentiles. The Southern Great Basin was slightly lower at 4,667; 16,877; and 51,858 ha, followed by the Columbia Basin at 4,119; 13,901; and 31,547 ha on the Columbia Basin at each of the three percentiles. The very largest fires in Columbia Basin did not exceed about 30,000 ha whereas in the other three management zones they exceeded 100,000 ha.

Fires were generally larger in the western region than in the eastern region (fig. 7). Fire sizes at the $25 \mathrm{th}, 50 \mathrm{th}$, and 75 th percentiles of cumulative fire area were 4,945; 17,436; and 56,460 ha in the western region compared to 2,$903 ; 11,578$; and 41,713 ha in the eastern region. This translated into fire sizes that were $41 \%, 34 \%$, and $26 \%$ higher in the western region at each of the three percentile levels. Another way of describing this difference is that one-half of the total fire area in the western region was represented by fire sizes greater than 17,436 ha, ranging from greater than 13,901 in the Columbia Basin to greater than 23,328 ha in the Northern Great Basin, whereas one-half of the fire area in eastern region was in fire sizes that were greater than 11,578 ha.

There was a notable shift in the distribution of fire area across fire sizes, with significant trends in the annual fire sizes at the at the 25th (unadjusted $p=0.02), 50$ th $(p=0.00)$, and 75 th $(p=0.00)$ percentiles of the cumulative fire area distributions calculated for each of the 30 years of the study (fig. 8). All p-values that were conservatively adjusted to control for false discovery rates also displayed high levels of certainty (adjusted $\mathrm{p}=0.01$ to $\mathrm{p}=0.04$ ). There also appeared to be an increase in annual fire size beginning in 2005 , especially at the 50 th and 75 th percentiles. 
Table 4. Fire recurrence area among fire recurrence classes in each vegetation type and management zone in the western range of the greater sage-grouse (1984-2013).

[ha, hectare; $\geq$, greater than or equal to; $\%$, percent; $\times$, times]

\begin{tabular}{|c|c|c|c|c|c|c|c|c|c|}
\hline \multirow[b]{2}{*}{ Vegetation type } & \multicolumn{7}{|c|}{ Fire recurrence (ha) } & \multirow{2}{*}{$\begin{array}{l}\text { Fire area } \geq 2 x \\
\text { Recurrent (ha) }\end{array}$} & \multirow{2}{*}{$\begin{array}{l}\text { Fire area } \geq 2 \times \\
\text { Recurrent }(\%)\end{array}$} \\
\hline & 1 & 2 & 3 & 4 & 5 & 6 & 7 & & \\
\hline \multicolumn{10}{|c|}{ Columbia Basin } \\
\hline Big Sagebrush & 24,808 & 15,326 & 5,223 & 5 & 0 & 0 & 0 & 20,554 & 45 \\
\hline Black/Low Sagebrush & 3 & 0 & 0 & 0 & 0 & 0 & 0 & 0 & 0 \\
\hline Desert Mixed Shrub & 8,575 & 4,951 & 796 & 16 & 2 & 0 & 0 & 5,764 & 40 \\
\hline Floodplain & 0 & 0 & 0 & 0 & 0 & 0 & 0 & 0 & 0 \\
\hline Grassland & 82,658 & 22,275 & 8,452 & 201 & 6 & 0 & 0 & 30,935 & 27 \\
\hline Mountain Brush & 3 & 0 & 0 & 0 & 0 & 0 & 0 & 0 & 0 \\
\hline Non-Sagebrush & 8,879 & 5,123 & 2,430 & 4 & 0 & 0 & 0 & 7,558 & 46 \\
\hline Columbia Basin Total & 124,926 & 47,675 & 16,901 & 227 & 8 & 0 & 0 & 64,811 & 34 \\
\hline \multicolumn{10}{|c|}{ Northern Great Basin } \\
\hline Big Sagebrush & 490,367 & 78,202 & 8,281 & 183 & 0 & 0 & 0 & 86,666 & 15 \\
\hline Black/Low Sagebrush & 276,447 & 33,929 & 9,469 & 75 & 0 & 0 & 0 & 43,472 & 14 \\
\hline Desert Mixed Shrub & 22,136 & 2,785 & 214 & 4 & 0 & 0 & 0 & 3,004 & 12 \\
\hline Floodplain & 0 & 0 & 0 & 0 & 0 & 0 & 0 & 0 & 0 \\
\hline Grassland & 17,523 & 1,612 & 153 & 6 & 0 & 0 & 0 & 1,771 & 9 \\
\hline Mountain Brush & 8,288 & 1,564 & 197 & 0 & 0 & 0 & 0 & 1,761 & 18 \\
\hline Non-Sagebrush & 196,314 & 19,015 & 2,306 & 1 & 0 & 0 & 0 & 21,322 & 10 \\
\hline Northern Great Basin Total & $1,011,074$ & 137,107 & 20,620 & 268 & 0 & 0 & 0 & 157,996 & 14 \\
\hline \multicolumn{10}{|c|}{ Snake River Plain } \\
\hline Big Sagebrush & $1,850,933$ & 499,526 & 169,577 & 49,858 & 11,748 & 2,780 & 438 & 733,928 & 28 \\
\hline Black/Low Sagebrush & 587,712 & 101,234 & 8,990 & 1,425 & 62 & 0 & 0 & 111,712 & 16 \\
\hline Desert Mixed Shrub & 48,377 & 9,407 & 1,708 & 2,156 & 390 & 141 & 4 & 13,807 & 22 \\
\hline Floodplain & 0 & 0 & 0 & 0 & 0 & 0 & 0 & 0 & 0 \\
\hline Grassland & 12,699 & 1,440 & 106 & 93 & 23 & 28 & & 1,690 & 12 \\
\hline Mountain Brush & 15,335 & 1,941 & 254 & 0 & 0 & 0 & 0 & 2,195 & 13 \\
\hline Non-Sagebrush & 315,108 & 39,775 & 11,069 & 4,034 & 945 & 136 & 26 & 55,985 & 15 \\
\hline
\end{tabular}




\begin{tabular}{|c|c|c|c|c|c|c|c|c|c|}
\hline \multirow[b]{2}{*}{ Vegetation type } & \multicolumn{7}{|c|}{ Fire recurrence (ha) } & \multirow{2}{*}{$\begin{array}{c}\text { Fire area } \geq 2 x \\
\text { Recurrent (ha) }\end{array}$} & \multirow{2}{*}{$\begin{array}{l}\text { Fire area } \geq 2 \times \\
\text { Recurrent }(\%)\end{array}$} \\
\hline & 1 & 2 & 3 & 4 & 5 & 6 & 7 & & \\
\hline Snake River Plain Total & $2,830,163$ & 653,324 & 191,705 & 57,566 & 13,168 & 3,086 & 468 & 919,316 & 25 \\
\hline \multicolumn{10}{|c|}{ Southern Great Basin } \\
\hline Big Sagebrush & 511,660 & 141,712 & 25,771 & 1,772 & 268 & 0 & 0 & 169,523 & 25 \\
\hline Black/Low Sagebrush & 156,745 & 22,166 & 3,635 & 122 & 2 & 0 & 0 & 25,925 & 14 \\
\hline Desert Mixed Shrub & 180,361 & 38,111 & 3,467 & 469 & 8 & 0 & 0 & 42,054 & 19 \\
\hline Floodplain & 0 & 0 & 0 & 0 & 0 & 0 & 0 & 0 & 0 \\
\hline Grassland & 0 & 0 & 0 & 0 & 0 & 0 & 0 & 0 & 0 \\
\hline Mountain Brush & 18,768 & 304 & 12 & 3 & 0 & 0 & 0 & 319 & 2 \\
\hline Non-Sagebrush & 277,375 & 29,558 & 3,038 & 126 & 6 & 0 & 0 & 32,729 & 11 \\
\hline Southern Great Basin Total & $1,144,909$ & 231,852 & 35,923 & 2,491 & 284 & 0 & 0 & 270,551 & 19 \\
\hline \multicolumn{10}{|c|}{ Western Management Zones Combined } \\
\hline Big Sagebrush & $2,877,767$ & 734,767 & 208,852 & 51,818 & 12,016 & 2,780 & 438 & $1,010,671$ & 26 \\
\hline Black/Low Sagebrush & $1,020,907$ & 157,329 & 22,094 & 1,621 & 64 & 0 & 0 & 181,108 & 15 \\
\hline Desert Mixed Shrub & 259,449 & 55,255 & 6,185 & 2,645 & 400 & 141 & 4 & 64,630 & 20 \\
\hline Floodplain & 0 & 0 & 0 & 0 & 0 & 0 & 0 & 0 & 0 \\
\hline Grassland & 112,880 & 25,328 & 8,712 & 299 & 29 & 28 & 0 & 34,396 & 23 \\
\hline Mountain Brush & 42,394 & 3,809 & 463 & 3 & 0 & 0 & 0 & 4,274 & 9 \\
\hline Non-Sagebrush & 797,676 & 93,472 & 18,843 & 4,166 & 951 & 136 & 26 & 117,593 & 13 \\
\hline Western Management Zones Total & $5,111,072$ & $1,069,959$ & 265,150 & 60,552 & 13,460 & 3,086 & 468 & $1,412,673$ & 22 \\
\hline
\end{tabular}




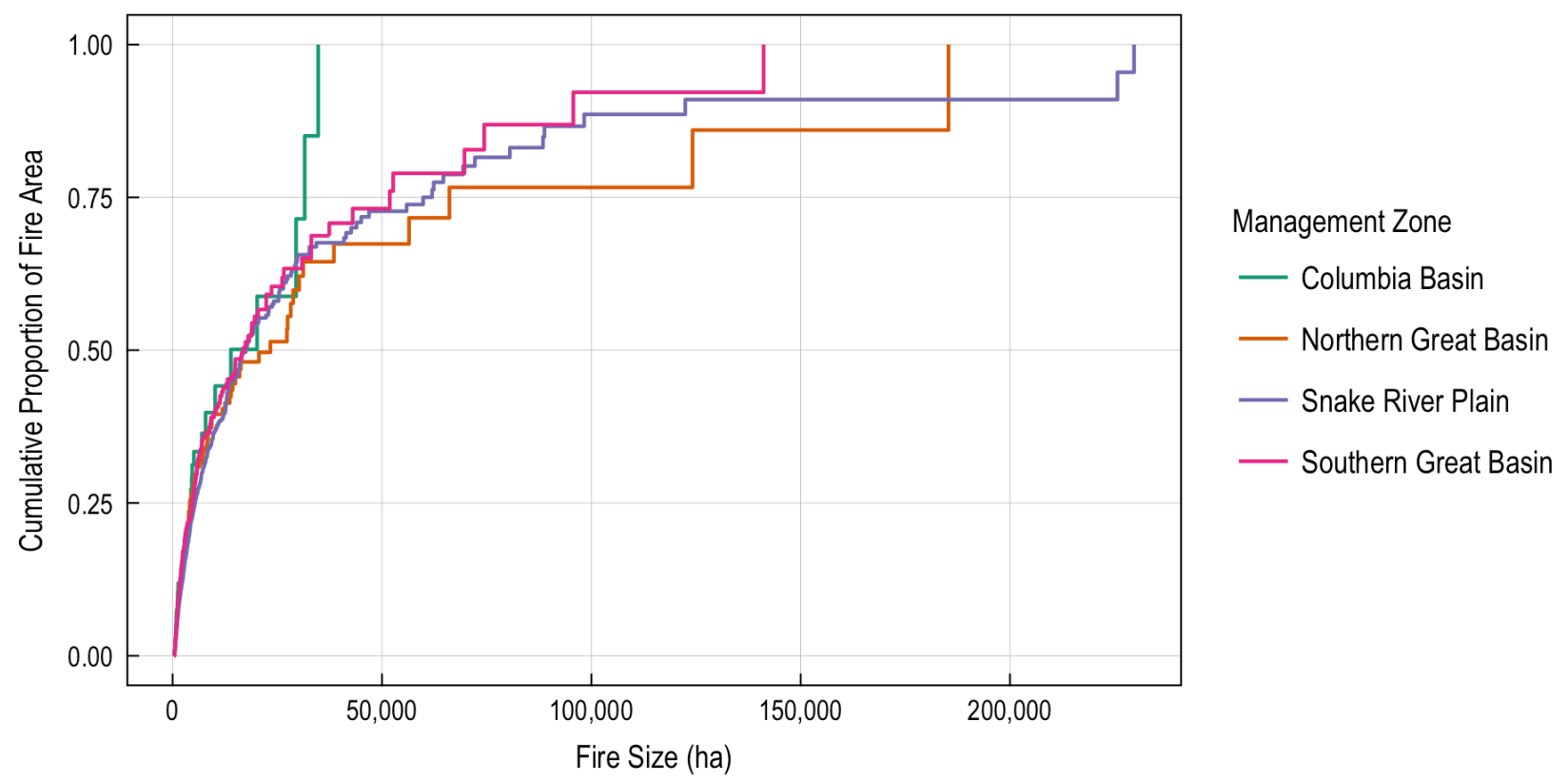

Figure 6. Cumulative fire area as a function of fire size in the four management zones in the western region of the greater sage-grouse range. Each distribution is based on all fires 1984-2013 in each management zone.

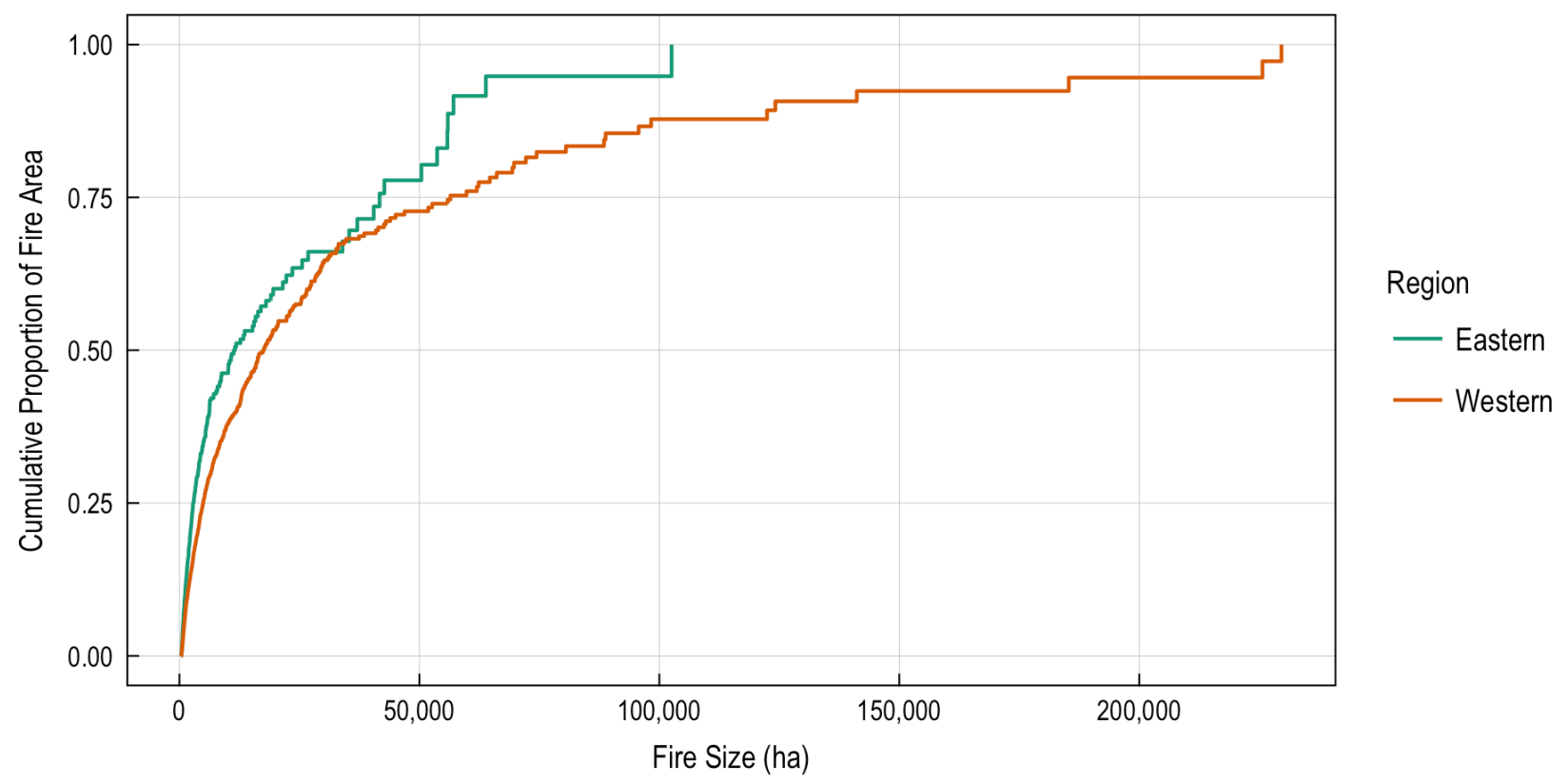

Figure 7. Cumulative fire area as a function of fire size in the western and eastern regions of the greater sagegrouse range. Each distribution is based on all fires 1984-2013 in each region. 


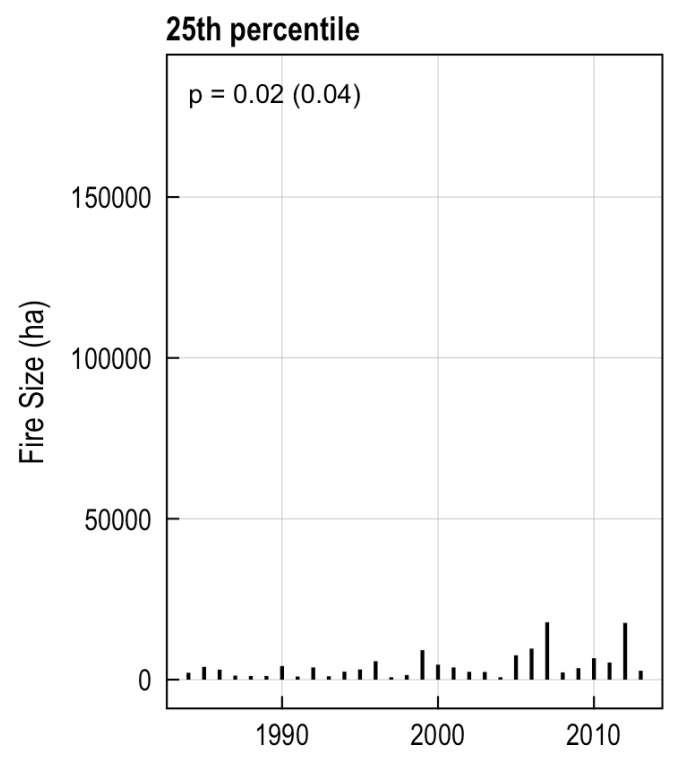

50th percentile

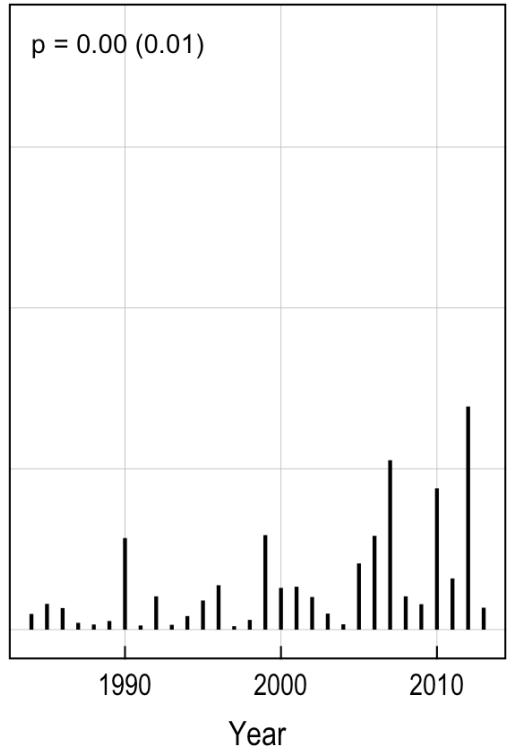

75th percentile

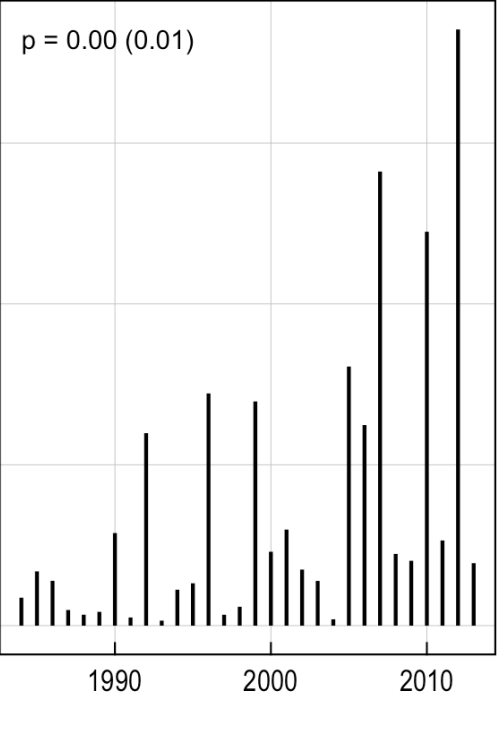

Figure 8. Fire size at the 25th, 50th, and 75th percentiles of the cumulative fire area distribution for each year 1984-2013 in the western region of the greater sage-grouse range. P-values are unadjusted and (adjusted for false discovery rate) to bracket the range of statistical confidence in the trends.

Fire Rotation.-Estimated fire rotation in the western region was shortest for Big Sagebrush at 99 years (table 5). Management zone values for this vegetation type ranged from a low of 61 and 78 years in the Columbia Basin and Snake River Plain, respectively, to highs of 148 and 150 years in the Northern Great Basin and Southern Great Basin, respectively. Fire rotation in Grassland was slightly longer at 127 years, ranging from a low of 106 years in the Columbia Basin, to a high of 146 years in the Snake River Plain, to 268 years in the Northern Great Basin. Black/Low Sagebrush had a fire rotation of 158 years ranging widely from 97 years in the Snake River Plain to 435 years in the Southern Great Basin. Desert Mixed Shrub displayed the next longest fire rotation at 206 years. Values ranged from lows of 152 and 176 years in the Columbia Basin and Snake River Plain, respectively, to highs of 208 and 315 years in the Southern Great Basin and Northern Great Basin, respectively. Mountain Brush represented the longest fire rotation in the western region at 320 years, ranging from extremes of 102 years in the Northern Great Basin to 580 years in the Southern Great Basin. 
Table 5. Fire rotation (years) in each vegetation type and management zone in the western range of the greater sage-grouse (1984-2013).

[Estimates for Non-Sagebrush were not reported (NR) because they represented an amalgam of numerous biophysical setting types with widely disparate fire regimes. Insufficient data (ID) existed to calculate fire rotation for some strata, either because 0 ha of fire area burned the strata or, in the case of Black/Low Sagebrush and Mountain Brush in the Columbia Basin, the amount of available area was very small (appendix 4)]

\begin{tabular}{lccccc}
\hline Vegetation type & $\begin{array}{c}\text { Columbia } \\
\text { Basin }\end{array}$ & $\begin{array}{c}\text { Northern } \\
\text { Great Basin }\end{array}$ & $\begin{array}{c}\text { Snake River } \\
\text { Plain }\end{array}$ & $\begin{array}{c}\text { Southern Great } \\
\text { Basin }\end{array}$ & $\begin{array}{c}\text { Western } \\
\text { Management } \\
\text { Zones Combined }\end{array}$ \\
\hline Big Sagebrush & 61 & 148 & 78 & 150 & 99 \\
Black/Low Sagebrush & ID & 134 & 97 & 435 & 158 \\
Desert Mixed Shrub & 152 & 315 & 176 & 208 & 206 \\
Floodplain & ID & ID & ID & ID & ID \\
Grassland & ID & 268 & 146 & N/A & 127 \\
Mountain Brush & ID & 102 & 198 & 580 & 320 \\
Non-Sagebrush & NR & NR & NR & NR & NR \\
\hline
\end{tabular}

Fire Season.-Fire season was longest in the Snake River Plain, followed by the Northern Great Basin, Southern Great Basin, and Columbia Basin (table 6). The Snake River Plain also had the earliest mean beginning date and latest ending date. Beginning dates for the Northern Great Basin and Southern Great Basin were similar, but ending dates were later for the former than the latter. The Columbia Basin by far had the latest beginning date and earliest end date in the western region. These estimates are considered to be fairly robust because of the high number of years in a given management zone that had two or more fires equal to or greater than 405 ha (1,000 acres): Snake River Plain ( $\mathrm{n}=30$ years), Southern Great Basin ( $\mathrm{n}=29$ years), Northern Great Basin ( $\mathrm{n}=28$ years), and Columbia Basin $(\mathrm{n}=24$ years).

The length of the fire season was fairly constant during the 30-year study period for all except the Southern Great Basin, which displayed a significantly increasing trend towards longer fire seasons (fig. 9).

Inferring the ecological significance of differences in fire season beginning, ending, and length among management zones is somewhat complicated by the fact that regions with greater numbers of fires will have increasing probability of some fires occurring very early or very late in the season. Thus, the mean beginning and ending dates, and season length, may therefore all be more extreme in geographic regions with more fires. This is particularly evident when comparing the values for individual management zones to those of all management zones combined with the western and eastern regions (see fire season results below), 
Table 6. Fire season beginning (day of year), ending (day of year), and length (days) in each management zone in the western range of the greater sage-grouse (1984-2013).

[Beginning and ending days are defined by the start date of the first and last fires equal to or greater than 405 ha (1,000 acres) each year and equal to or greater than two fires in a year are required to generate a fire season length value]

\begin{tabular}{lccccc}
\hline & $\begin{array}{c}\text { Columbia } \\
\text { Basin }\end{array}$ & $\begin{array}{c}\text { Northern } \\
\text { Great Basin }\end{array}$ & $\begin{array}{c}\text { Snake River } \\
\text { Plain }\end{array}$ & $\begin{array}{c}\text { Southern Great } \\
\text { Basin }\end{array}$ & $\begin{array}{c}\text { Western } \\
\text { Management Zones } \\
\text { Combined }\end{array}$ \\
\hline Length (days) & 26 & 85 & 111 & 72 & 138 \\
Beginning (day of year) & 189 & 172 & 165 & 171 & 144 \\
Ending (day of year) & 222 & 264 & 275 & 245 & 282 \\
Years with $\geq 2$ Fires (count) & 24 & 28 & 30 & 29 & 30 \\
\hline
\end{tabular}

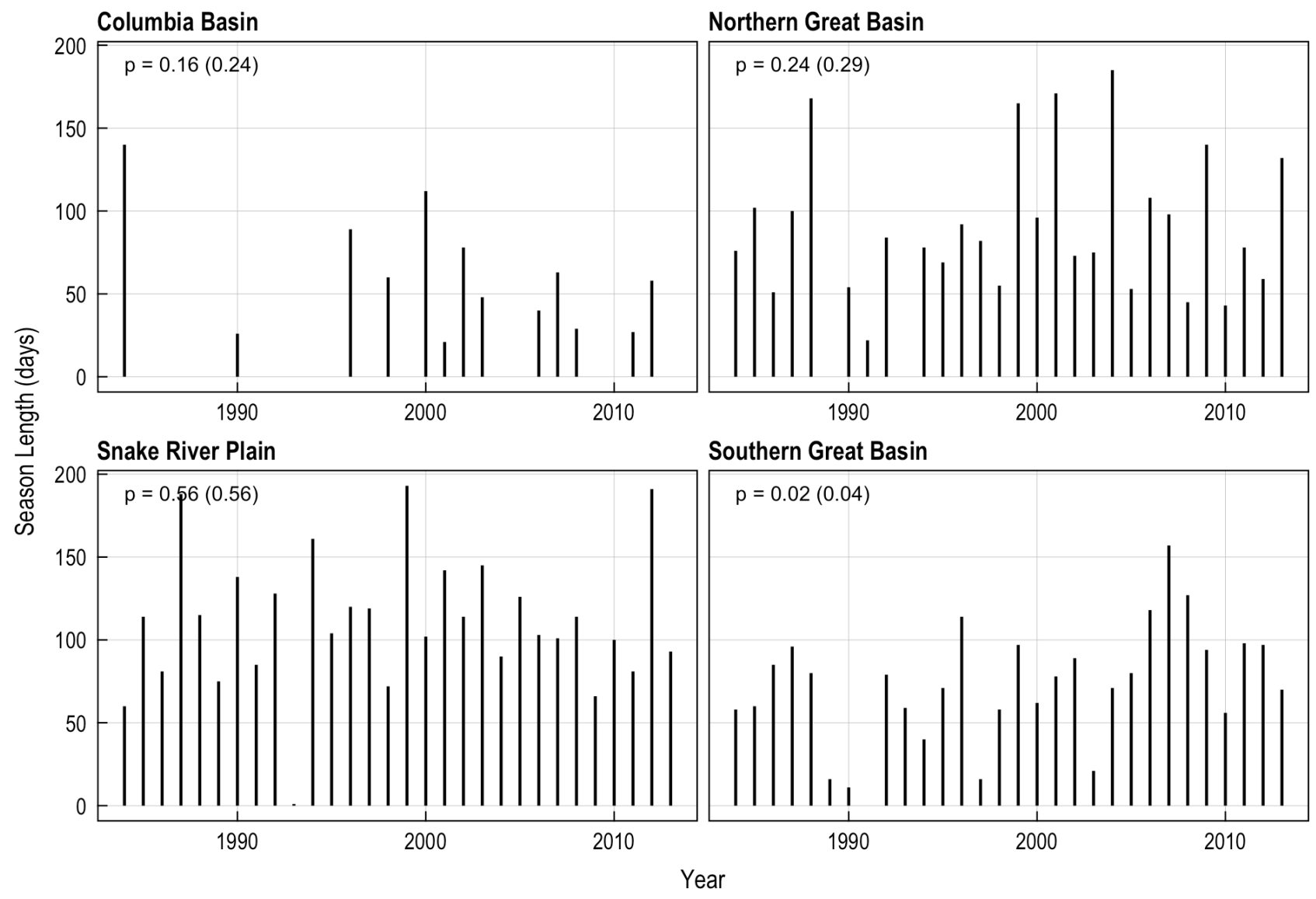

Figure 9. Fire season length for each year 1984-2013 in the four management zones in the western region of the greater sage-grouse range. P-values are unadjusted and (adjusted for false discovery rate) to bracket the range of statistical confidence in the trends. 


\section{Eastern Regional Fire Area and Other Fire Regime Characteristics}

Fire Area.- In the eastern region, fire area encompassed 1,891,979 (4,678,244 acres; 7,310 mi²) (table 7, fig. 3), constituting 5\% of the total available area in the eastern region $(37,658,979$ ha, appendix 5). Even accounting for recurrent fire, $5 \%$ of available surface area in the eastern region burned one or more times. This fire area represented a small fraction $(18 \%)$ of the total fire area across all sage-grouse wildland areas rangewide, even though the eastern region contributed almost one-half $(49 \%)$ of the total area in this study.

Two-thirds (66\%) of the fire area in the eastern region was in the Great Plains management zone, and $62 \%$ of that area was in Grassland (table 7). The other one-third (31\%) was in the Wyoming Basin, mostly in Big Sagebrush (57\%) and Non-Sagebrush (39\%) vegetation types. The remaining 2\% of the fire area occurred in the Colorado Plateau. The rates of burning were all relatively low across the eastern region, most around $5 \%$ of total available area.

Most of the fire area in the eastern region occurred in areas of relatively high resilience/resistance (Cryic, Frigid/Ustic) (appendix 13). These fire areas were mostly in Grassland, Floodplain, Mountain Brush, and Non-Sagebrush vegetation types. Only fire area in Big Sagebrush in the Wyoming Basin occurred on relatively low resilience/resistance landscapes (Frigid/Aridic, Mesic/Aridic).

The strongest evidence of increasing fire area were in Non-Sagebrush (unadjusted $\mathrm{p}=0.01$ ), Grassland ( $\mathrm{p}=0.03$ ), and Floodplain ( $\mathrm{p}=0.03$ ) (fig. 10). These patterns were mostly due to the Great Plains and Wyoming Basin. The former also displayed some evidence of increasing fire area in Big Sagebrush $(p=0.06)$ and Black/Low Sagebrush $(p=0.07)$. All $p$-values that were conservatively adjusted to control for false discovery rates associated with test multiplicity (Benjamini and Yekutieli, 2001) displayed very low levels of certainty (adjusted $\mathrm{p}=0.50 \mathrm{po} \mathrm{p}=1.00$ ). The very high number of separate tests that were adjusted for and lack of high significant unadjusted $\mathrm{p}=$ values are the likely reasons for the high adjusted p-values. 
Table 7. Fire area, percentage of total fire area, and percentage of available area for each vegetation type in the management zones of the eastern region of the greater sage grouse range (1984-2013).

\begin{tabular}{|c|c|c|c|}
\hline Vegetation type & $\begin{array}{c}\text { Fire area } \\
\text { (hectares) }\end{array}$ & $\begin{array}{c}\text { Percentage of } \\
\text { fire area }\end{array}$ & $\begin{array}{l}\text { Percentage of } \\
\text { available area }\end{array}$ \\
\hline \multicolumn{4}{|c|}{ Colorado Plateau } \\
\hline Big Sagebrush & 4,175 & 10 & 4 \\
\hline Black/Low Sagebrush & 57 & 0 & $<1$ \\
\hline Desert Mixed Shrub & 230 & 1 & 1 \\
\hline Floodplain & 0 & 0 & 0 \\
\hline Grassland & 0 & 0 & 0 \\
\hline Mountain Brush & 5,580 & 14 & 7 \\
\hline Non-Sagebrush & 30,601 & 75 & 8 \\
\hline $\begin{array}{l}\text { Colorado Plateau Vegetation } \\
\text { Total }\end{array}$ & 40,643 & 100 & 6 \\
\hline \multicolumn{4}{|c|}{ Great Plains } \\
\hline Big Sagebrush & 191,560 & 15 & 7 \\
\hline Black/Low Sagebrush & 0 & 0 & $<1$ \\
\hline Desert Mixed Shrub & 0 & 0 & 0 \\
\hline Floodplain & 44,732 & 4 & 5 \\
\hline Grassland & 779,665 & 62 & 6 \\
\hline Mountain Brush & 1,734 & 0 & 6 \\
\hline Non-Sagebrush & 238,566 & 19 & 11 \\
\hline Great Plains Vegetation Total & $1,256,257$ & 100 & 7 \\
\hline \multicolumn{4}{|c|}{ Wyoming Basin } \\
\hline Big Sagebrush & 337,913 & 57 & 3 \\
\hline Black/Low Sagebrush & 1,088 & 0 & 3 \\
\hline Desert Mixed Shrub & 1,382 & 0 & 1 \\
\hline Floodplain & 1,050 & 0 & 2 \\
\hline Grassland & 17,881 & 3 & 5 \\
\hline Mountain Brush & 4,096 & 1 & 1 \\
\hline $\begin{array}{l}\text { Non-Sagebrush } \\
\text { Wyoming Basin Vegetation }\end{array}$ & 231,669 & 39 & 5 \\
\hline Total & 595,079 & 100 & 4 \\
\hline \multicolumn{4}{|c|}{ Eastern Management Zones Combined } \\
\hline Big Sagebrush & 533,648 & 28 & 4 \\
\hline Black/Low Sagebrush & 1,144 & 0 & 3 \\
\hline Desert Mixed Shrub & 1,612 & 0 & 1 \\
\hline Floodplain & 45,783 & 2 & 5 \\
\hline Grassland & 797,546 & 42 & 6 \\
\hline Mountain Brush & 11,410 & 1 & 2 \\
\hline Non-Sagebrush & 500,836 & 26 & 7 \\
\hline Eastern Zones Vegetation Total & $1,891,979$ & 100 & 5 \\
\hline
\end{tabular}




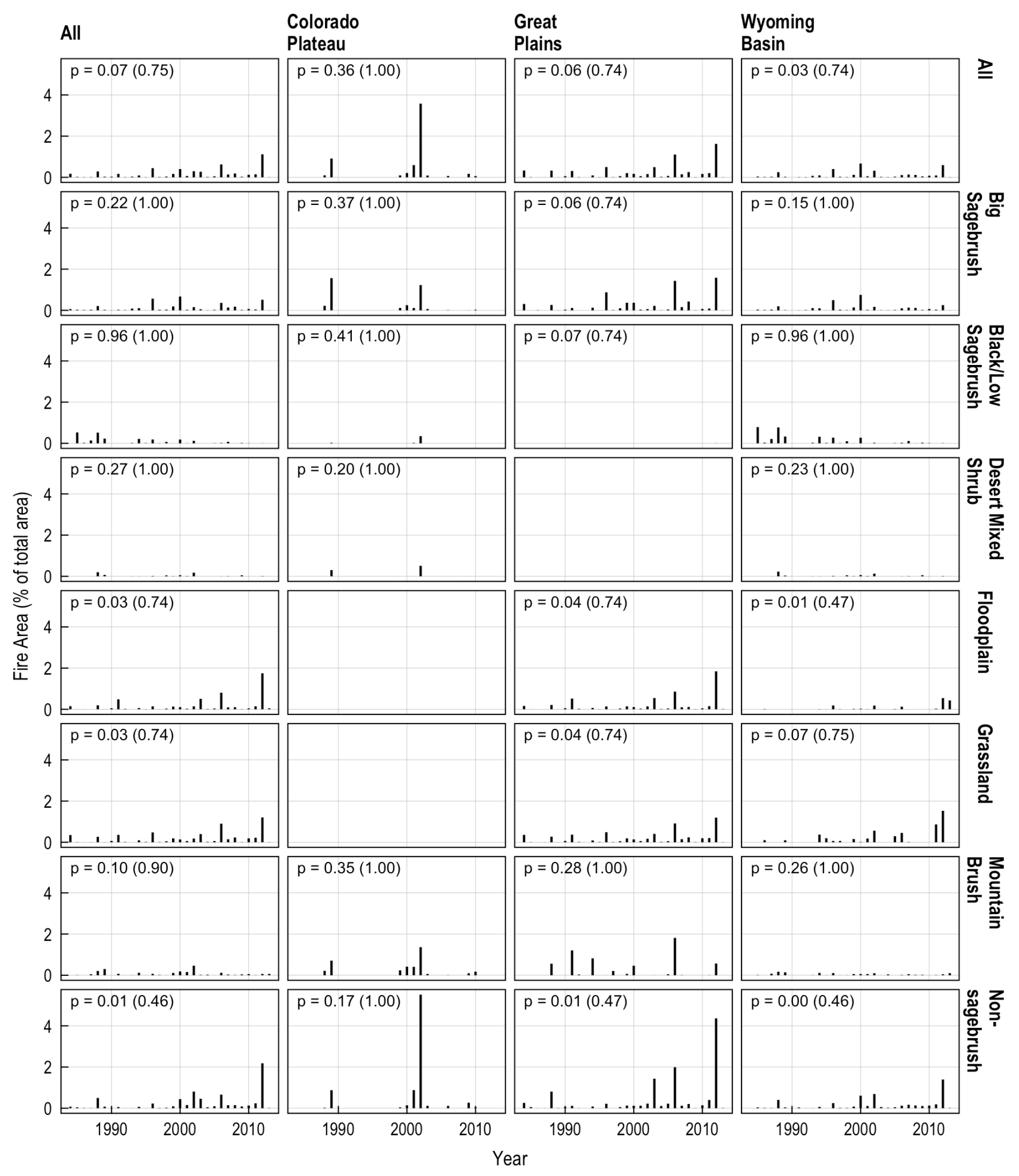

Figure 10. Fire area for each year 1984-2013 in major vegetation types and the three management zones in the eastern region of the greater sage-grouse range. P-values are unadjusted and (adjusted for false discovery rate) to bracket the range of statistical confidence in the trends. 
Fire Recurrence.--Recurrent fire area encompassed 123,479 ha, or 22\% of the total fire area in the eastern region (table 8$)$. The majority $(80 \%)$ of the recurrent fire area occurred in the Great Plains management zone. The Wyoming Basin (19\%) and Colorado Plateau (1\%) round out the percentages of recurrent fire area in the eastern region. Most of the recurrent fire area occurred in Grassland (52\%) (table 8). Big sagebrush (25\%) was the other major contributor of recurrent fire.

Fire Size. - The size distributions of fire area across fire sizes in the eastern region over the 30year study period differed widely among management zones (fig. 11). Fire sizes at the 25th, 50th, and 75 th percentiles of cumulative fire area were much higher in the Great Plains at 3,568; 16,348; and 50,424 ha than in the Wyoming Basin at 1,991; 6,027; and 19,042 ha. Thus, one-half of the fire area in the Great Plains occurred in fires greater than 16,348 ha, whereas in the Wyoming Basin one-half of the fire area was in fires greater than 6,027 ha. Cumulative fire area in the Colorado Plateau was not comparable to the other regions because there was only a few fires greater than 1,000 ha (fig. 11).

As mentioned above in the western regional results for fire size, the fires were much smaller in the eastern region than in the western region (fig. 7). Also, in contrast to the western region which displayed notable shifts in fire area size distribution over time (fig. 8), the eastern region displayed no such trend (fig. 12).

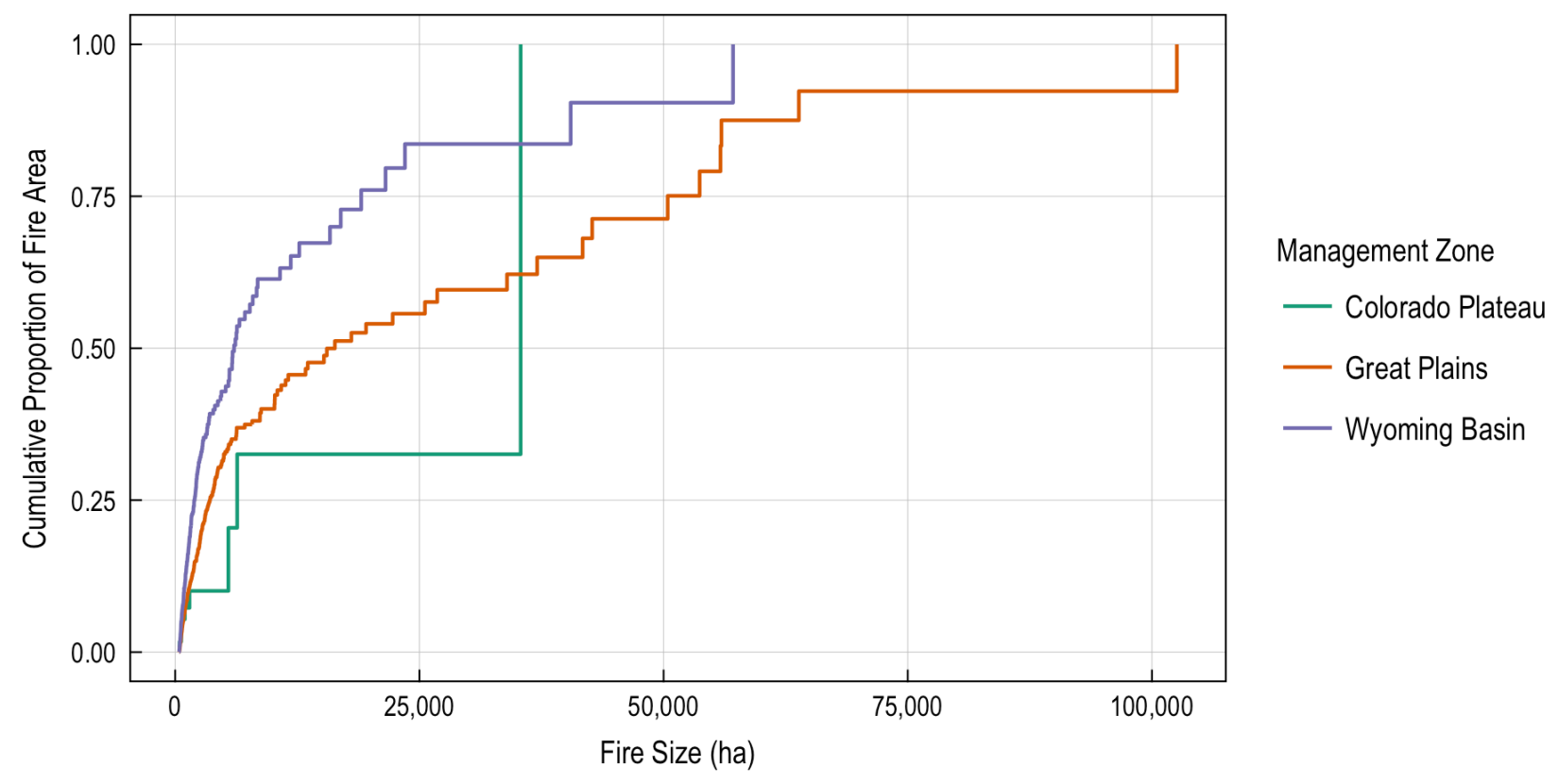

Figure 11. Cumulative fire area as a function of fire size in the three management zones in the eastern region of the greater sage-grouse range. Each distribution is based on all fires 1984-2013 in each management zone. 

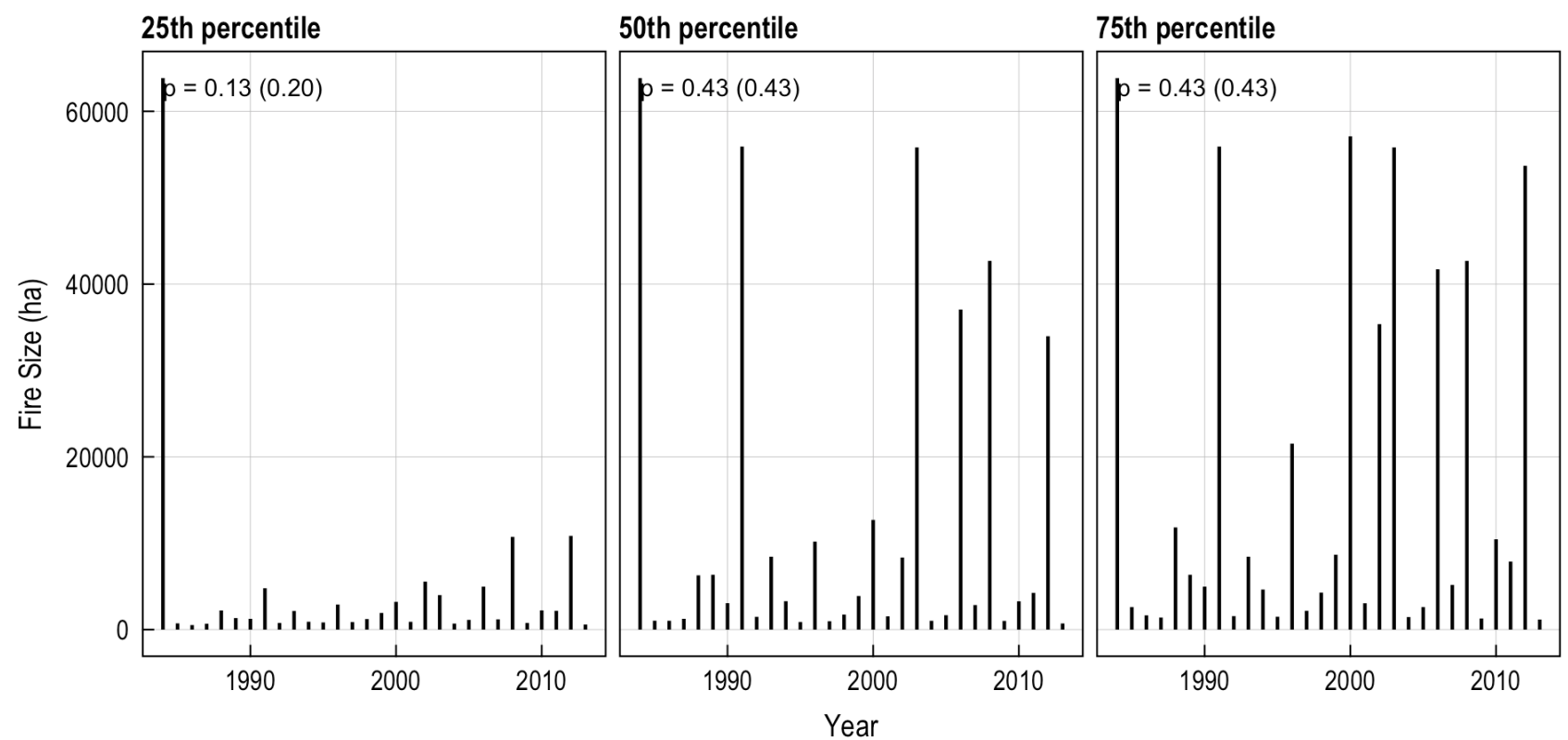

Figure 12. Fire size at the 25 th, 50 th, and 75 th percentiles of the cumulative fire area distribution for each year 1984-2013 in the eastern region of the greater sage-grouse range. P-values are unadjusted and (adjusted for false discovery rate) to bracket the range of statistical confidence in the trends. 
Table 8. Fire recurrence area among fire recurrence classes in each vegetation type and management zone in the eastern region of the greater sage-grouse (1984-2013).

[ha, hectare; $\geq$, greater than or equal to; $\%$, percent; $\times$, times]

\begin{tabular}{|c|c|c|c|c|c|c|}
\hline \multirow[b]{2}{*}{ Vegetation type } & \multicolumn{4}{|c|}{ Fire Recurrence } & \multirow{2}{*}{$\begin{array}{l}\text { Fire Area } \geq 2 \times \\
\text { Recurrent (ha) }\end{array}$} & \multirow{2}{*}{$\begin{array}{l}\text { Fire Area } \geq 2 \times \\
\text { Recurrent }(\%)\end{array}$} \\
\hline & 1 & 2 & 3 & 4 & & \\
\hline \multicolumn{7}{|c|}{ Colorado Plateau } \\
\hline Big Sagebrush & 3,896 & 139 & 0 & 0 & 139 & 3 \\
\hline Black/Low Sagebrush & 54 & 1 & 0 & 0 & 1 & 2 \\
\hline Desert Mixed Shrub & 217 & 6 & 0 & 0 & 6 & 3 \\
\hline Floodplain & 0 & 0 & 0 & 0 & 0 & NA \\
\hline Grassland & 0 & 0 & 0 & 0 & 0 & NA \\
\hline Mountain Brush & 4,897 & 342 & 0 & 0 & 342 & 7 \\
\hline Non-Sagebrush & 28,047 & 1,277 & 0 & 0 & 1,277 & 4 \\
\hline Colorado Plateau Vegetation Total & 37,111 & 1,766 & 0 & 0 & 1,766 & 5 \\
\hline \multicolumn{7}{|c|}{ Great Plains } \\
\hline Big Sagebrush & 158,439 & 15,880 & 453 & 0 & 16,333 & 9 \\
\hline Black/Low Sagebrush & 0 & 0 & 0 & 0 & 0 & NA \\
\hline Desert Mixed Shrub & 0 & 0 & 0 & 0 & 0 & NA \\
\hline Floodplain & 38,617 & 2,843 & 142 & 1 & 2,986 & 7 \\
\hline Grassland & 653,100 & 59,221 & 2,672 & 27 & 61,920 & 9 \\
\hline Mountain Brush & 1,651 & 42 & 0 & 0 & 42 & 2 \\
\hline Non-Sagebrush & 203,371 & 15,873 & 1,109 & 30 & 17,013 & 8 \\
\hline Great Plains Vegetation Total & $1,055,178$ & 93,859 & 4,376 & 58 & 98,293 & 9 \\
\hline \multicolumn{7}{|c|}{ Wyoming Basin } \\
\hline Big Sagebrush & 308,969 & 14,307 & 110 & 0 & 14,417 & 4 \\
\hline Black/Low Sagebrush & 951 & 68 & 0 & 0 & 68 & 7 \\
\hline Desert Mixed Shrub & 1,290 & 46 & 0 & 0 & 46 & 3 \\
\hline Floodplain & 982 & 34 & 0 & 0 & 34 & 3 \\
\hline Grassland & 13,833 & 2,024 & 0 & 0 & 2,024 & 13 \\
\hline Mountain Brush & 3,631 & 232 & 0 & 0 & 232 & 6 \\
\hline Non-Sagebrush & 218,472 & 6,594 & 3 & 0 & 6,597 & 3 \\
\hline Wyoming Basin Vegetation Total & 548,128 & 23,306 & 113 & 0 & 23,419 & 4 \\
\hline \multicolumn{7}{|c|}{ Eastern Management Zones Combined } \\
\hline Big Sagebrush & 471,305 & 30,327 & 563 & 0 & 30,890 & 6 \\
\hline Black/Low Sagebrush & 1,004 & 70 & 0 & 0 & 70 & 7 \\
\hline Desert Mixed Shrub & 1,507 & 52 & 0 & 0 & 52 & 3 \\
\hline Floodplain & 39,599 & 2,877 & 142 & 1 & 3,020 & 7 \\
\hline Grassland & 666,933 & 61,245 & 2,672 & 27 & 63,944 & 9 \\
\hline Mountain Brush & 10,178 & 615 & 0 & 0 & 616 & 6 \\
\hline Non-Sagebrush & 449,889 & 23,744 & 1,112 & 30 & 24,887 & 5 \\
\hline Eastern Zones Vegetation Total & $1,640,416$ & 118,931 & 4,489 & 58 & 123,479 & 7 \\
\hline
\end{tabular}


Fire Rotation.-Estimated fire rotation in the eastern region was shortest for Grassland at 526 years (table 9). Management zone values for this vegetation type ranged from 524 years in the Great Plains to 603 years in the Wyoming Basin. Floodplain was slightly higher at 585 years, but ranged more widely from 555 years in the Great Plains to 1,853 years in the Wyoming Basin. Big Sagebrush was a couple hundred years longer at 810 years, ranging from 445 years in the Great Plains to 1,017 years in the Wyoming Basin (table 9). Black/Low Sagebrush displayed a fire rotation of 1,251 years, with 883 years in the Wyoming Basin and 7,533 years in the Colorado Plateau. Mountain Brush was a bit higher at 1,348 years, ranging from 516 years in the Great Plains to 2,433 in the Wyoming Basin. Desert Mixed Shrub had the longest fire rotation by far at 4,366 years, ranging from 3,672 years in the Colorado Plateau to 4,481 years in the Wyoming Basin.

Fire Season.-Fire season length was similar in the Great Plains (mean $=100$ days) and Wyoming Basin (mean $=96$ days) (table 10). Beginning dates were earlier for the Great Plains $($ mean $=$ 147 days, day of year $=$ May 27) than for the Wyoming Basin $($ mean $=163$ days, day of year $=$ June 12), and so, too, were the ending dates for the former (mean $=255$ days, day of year = September 12) than the latter $($ mean $=265$ days, day of year $=$ September 22). The Colorado Plateau was anomalous in having mean beginning and ending dates for the fire season the same (mean $=194$ days, day of year $=$ July 13), and the mean season length 0 days. This was due to the very small number of years with at least two fires equal to or greater than 405 ha (1,000 acres) ( $\mathrm{n}=10$ years). The other two eastern region management zones each had $n=28$ years with two or more of these fires.

The length of the fire season significantly increased during the 30-year study period for both the Great Plains and the Wyoming Basin (fig. 13). Fire seasons were shorter in the first decade than in the latter two decades of the study period.

Table 9. Fire rotation (years) in each vegetation type and management zone in the eastern region of the greater sage grouse (1984-2013).

[Estimates for Non-Sagebrush were not reported (NR) because they represented an amalgam of numerous biophysical setting types with widely disparate fire regimes. Insufficient data (ID) existed to calculate fire rotation for some strata, either because 0 ha of fire area burned the strata or, in the case of Black/Low Sagebrush and Mountain Brush in the Columbia Basin, the amount of available area was very small (appendix 4)]

\begin{tabular}{lccrc}
\hline \multicolumn{1}{c}{ Vegetation type } & Colorado Plateau & Great Plains & Wyoming Basin & $\begin{array}{c}\text { Eastern Management } \\
\text { Zones combined }\end{array}$ \\
\hline Big Sagebrush & \multicolumn{3}{c}{ Modern Fire Rotation (Current Study) } \\
Black/Low Sagebrush & 7,533 & 445 & 1,017 & 810 \\
Desert Mixed Shrub & 3,672 & ID & 883 & 1,251 \\
Floodplain & ID & ID & 4,481 & 4,366 \\
Grassland & ID & 555 & 1,853 & 585 \\
Mountain Brush & 811 & 524 & 603 & 526 \\
Non-Sagebrush & NR & 516 & 2,433 & 1,348 \\
& & NR & NR & NR \\
\hline
\end{tabular}


Table 10. Fire season variables (mean values) in each management zone in the eastern range of the greater sage grouse (1984-2013).

[Beginning and ending days are defined by the start date of the first and last fires equal to or greater than 405 ha $(1,000$ acres) each year and equal to or greater than two fires in a year are required to generate a fire season length value]

\begin{tabular}{lcccc}
\hline & Colorado Plateau & Great Plains & Wyoming Basin & $\begin{array}{c}\text { Eastern } \\
\text { Management } \\
\text { Zones Combined }\end{array}$ \\
\hline Length (days) & 0 & 100 & 96 & 142 \\
Beginning (day of year) & 194 & 147 & 163 & 131 \\
Ending (day of year) & 194 & 255 & 265 & 273 \\
Years with $\geq 2$ Fires (count) & 10 & 28 & 28 & 30 \\
\hline
\end{tabular}

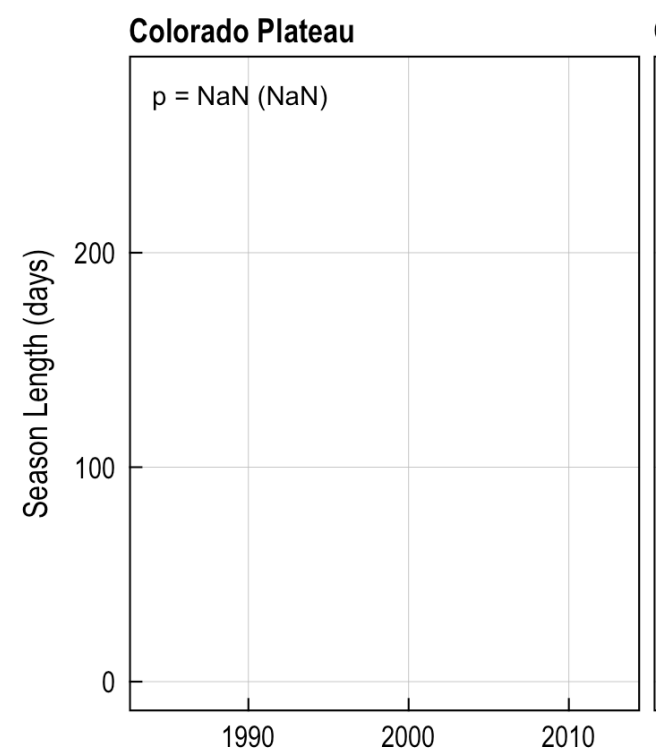

Great Plains

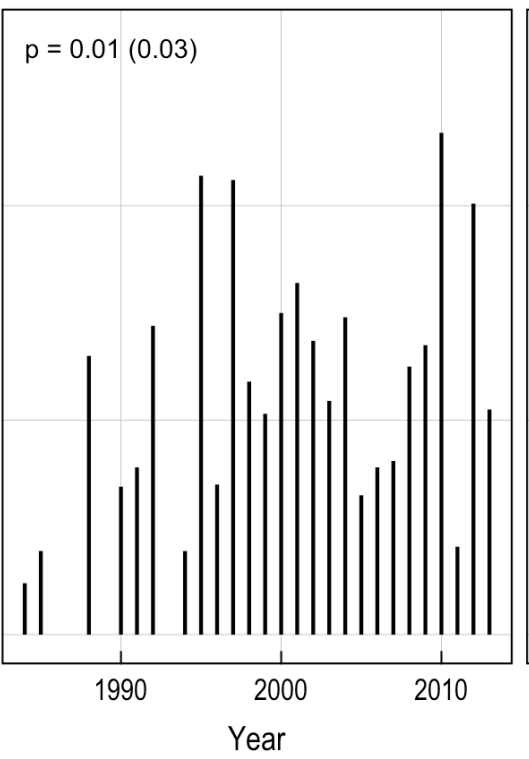

Wyoming Basin

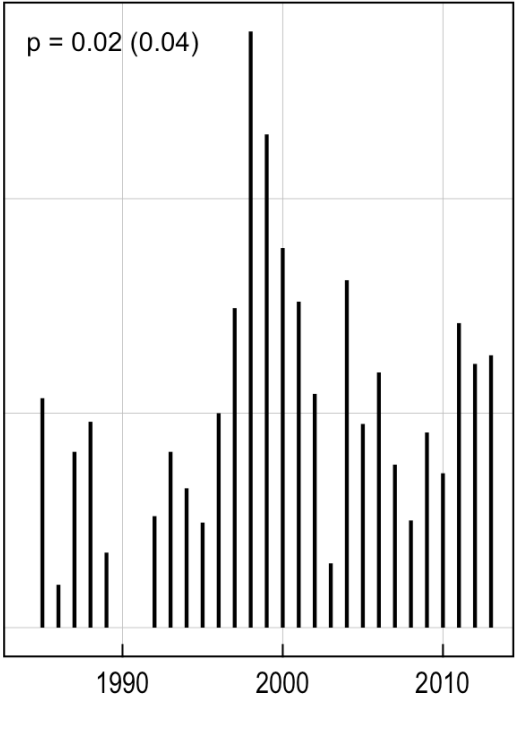

Figure 13. Fire season length for each year 1984-2013 in the three management zones in the eastern region of the greater sage-grouse range. P-values are unadjusted and (adjusted for false discovery rate) to bracket the range of statistical confidence in the trends. 


\section{Discussion of Fire Patterns}

\section{Fire Area}

\section{Fire Area Amount and Percentage of Available Area}

We know of no published studies that are comparable with the results we present for fire area and fire area as a percentage of available area in sage-grouse management zones and vegetation types. The only possible comparison might be a series of figures (Miller and others, 2011; figs. 10.11-10.15), which suggest similar ordinal ranking of total fire area as those reported for some of the sage-grouse management zones in the current study. We therefore focus below on the potential ecological implications of the fire area patterns we reported, rather than comparisons with other studies.

The significant amount fire area in Big Sagebrush, and to a lesser degree Black/Low Sagebrush and Desert Mixed Scrub, across the range of the greater sage-grouse should be a great concern for conservation efforts. These relatively hot/dry, low productivity landscapes recover more slowly following fire and are more susceptible to invasion by non-native invasive grasses than are higher resilience/resistance vegetation types in the sagebrush biome (Chambers and others, 2014a, 2014b, Brooks and others, in press). In addition, increased dominance by non-native grasses such as cheatgrass can increase fire frequency and promote a grass/fire cycle (D'Antonio and Vitousek, 1992; Brooks and others, 2004; Brooks, 2008), potentially leading to type-conversion of native sagebrush into non-native annual grasslands (Brooks, 2008, fig. 3.7), and thus significantly reducing habitat quality for the greater sage-grouse (Knick and others, 2013).

As mentioned in the introduction to this report, invasive species and fire are among the top three greatest threats to the greater sage-grouse (U.S. Fish and Wildlife Service, 2005). However, it is actually the interaction between the two, via the grass-fire cycle, which is arguably the single greatest threat, at least in the western regions. The steps of inference to determine that an altered fire regime has occurred include: (1) documenting that a plant invasion or set of invasions has altered fuelbed characteristics; (2) demonstrating that these fuelbed changes alter the spatial and/or temporal distribution of fire on the landscape; and (3) showing that the new fire regime promotes the dominance of the fuels that drive it (Brooks, 2008; fig. 3.6). Cheatgrass is known to increase fine fuel loads, horizontal continuity, and ignitability of fuels (Brooks and Pyke, 2001; Rice and others, 2001; Brooks, 2008). These fuelbed characteristics can lead to increased fire size, frequency, and seasonal window of burning. These changes make it increasing difficult for woody sagebrush steppe species to recover, leading to replacement of coarse woody fuels by fine herbaceous grasses. Cheatgrass can recover very quickly producing fuel beds that can carry fire after as few as 5 years (Whisenant, 1989), but most native woody species are adapted to a longer fire-return intervals ranging from many decades to over a century or more (Rice and others, 2001). Thus, cheatgrass both promotes frequent fire and recovers soon following fire, creating a grass/fire cycle that has converted vast landscapes of native sagebrush vegetation types to nonnative annual grasslands (Rice and others, 2001; Menakis and others, 2003). 
Few would argue that the grass/fire cycle is not a substantial threat to the greater sage-grouse habitat, but it can be difficult to define exactly where thresholds have been crossed and a self-sustaining grass/fire cycle has become established. In fact, there are relatively few studies published from around the world that specifically document evidence for cases where a grass/fire cycle has become established (for example Rossiter and others, 2003; Setterfield and others, 2013; Bowman and others, 2014). Although this task is beyond the scope of the current study, the information we present on patterns of fire regime characteristics provide critical pieces of the puzzle that ultimately can be used to develop risk assessments for the establishment potential of a grass/fire cycle across the range of the greater sagegrouse.

The concern regarding the preponderance of fire area in vegetation types of low resistance and resilience is clearly well justified, but other evidence somewhat tempers this concern. For example, the strongest evidence suggesting an increasing trend in annual fire area is from relatively high resilience/resistance vegetation types, specifically Floodplain, Grassland, and Mountain Brush, and especially for Non-Sagebrush. These types may actually benefit from increased fire area after a century or more of reduce fire conditions. Such a situation has been documented in Grasslands where inappropriate grazing practices reduced fuel loads below the threshold that could easily carry fire, resulting in reduced fire frequency and increased abundance of woody species (Ratajczak and others, 2014). Thus, not all increasing trends in fire area are necessarily cause for alarm and fire threats analyses should take into account the differing implications of increased fire in low resilience/resistance versus high resilience/resistance landscapes.

\section{Fire Area Trends}

Increasing trends in annual fire area have been widely cited to occur in the Western United States (Balch and others, 2013; Dennison and others, 2014), but few estimates have focused on the regions that generally coincided with the geographic range of the greater sage-grouse, and those that do are not exactly comparable with the current study. One such study was based on an incomplete and inconsistently derived fire dataset and a different time interval (1980-2007) and did not parse the analyses by vegetation type (Miller and others, 2011). Another study was based on a more complete and consistent dataset ( $\geq 405$ ha MTBS fires), across another time interval (1984-2008), but utilized current rather than potential vegetation layers and may therefore be susceptible to potential cause-and-effect confounders when interpreting the resulting fire patterns (Baker, 2013). Neither of those previous studies focused specifically on what we define as sage-grouse wildland areas, relevant for habitat conservation across the range of sage-grouse (see section, "Study Area" for description of this term). Those differences aside, Miller and others (2011) and Baker (2013) provide the closest estimates of recent patterns of fire area that are comparable for this current study.

The current study reported evidence of increased fire area for all vegetation types combined in the Wyoming Basin, Snake River Plain, Columbia Basin, and Great Plains, but not in the Northern Great Basin, Southern Great Basin, and Colorado Plateau. Miller and others (2011) reported increased fire area in all regions except the Snake River Plain, but also reported increases in the Northern Great Basin and Southern Great Basin. Baker (2013) reported increasing fire area in the Colorado Plateau and Columbia Basin, but not in other regions. The current study also highlighted relatively strong evidence 
of increases in fire area in Big Sagebrush of the Columbia Basin and Snake River Plain, and weaker evidence in the Great Plains. Baker (2013) reports similar fire area increases in Big Sagebrush of the Columbia Plateau, but not in the Snake River Plain. There are many other examples of relatively poor concurrence in results between these previous two studies (Miller and others, 2011; Baker, 2013) and the current study in trends in fire area integrated across all vegetation types in the range of greater sagegrouse.

Difference among study findings reflect a common difficulty when comparing the results of fire history studies that are based on differing spatial and temporal scales, or that use different datasets. However, because of our specific focus on greater sage-grouse habitat across its entire range, our use of a longer fire period and more accurate fire dataset, and our focus on the biophysical conditions capable of supporting sagebrush communities, we suggest that our results are appropriate for use in planning efforts focused on greater sage-grouse conservation.

\section{Fire Recurrence}

The prevalence of recurrent fire in Big Sagebrush is of similar concern as that explained above for fire area patterns. This vegetation type is dominated by relatively hot/dry, low productivity landscapes that have relatively low resilience/resistance. As a result, it has higher probability of transitioning to a grass/fire cycle than cooler/wetter landscapes. The presence of recurrent fire, rather than simply fire per se, serves as an additional source of concern because shortened fire-return intervals are a hallmark of the grass/fire cycle (D'Antonio and Vitousek, 1992) and a key piece of evidence that indicates its presence (Brooks, 2008). Thus, areas with recurrent fire in Big Sagebrush and other low resilience/resistance vegetation types such as Black/Low Sagebrush and Desert Mixed Shrub are at a high probability of transitioning to a grass/fire cycle.

As fire recurrence over a given time period increases and the average fire return interval decreases, conditions become increasing more suitable for the persistence of annual plants such as cheatgrass and less suitable for the persistence of woody perennials such as sagebrush. A seminal study documented this dynamic in Big Sagebrush on the Snake River Plain (Whisenant, 1989). Declines were reported in fire return intervals from 60 to 110 years historically to $3-5$ years during the 1960 s through 1980s across large portions of that region. Increased fire frequency was associated with increased frequency of cheatgrass and other annuals, decreased frequency of sagebrush, others shrubs, and perennial grasses, and decreased plant species diversity. These changes all represent dramatic declines in habitat quality for the greater sage-grouse.

Of the total recurrent fire area, we reported (1.4 million ha), roughly two-thirds of that area (919,316 ha) occurred in the Snake River Plain management zone (table 4) during the 30-year study period. Most of that recurrent fire area burned twice $(71 \%)$ resulting in an average fire return interval of 15 years for those areas, and the remainder $(29 \%)$ burned three or more times for an average fire return interval of 7.5 years or less. However, an analysis of recurrent fire area as a proportion of total available sage-grouse wildland area in the Snake River Plain (16,496,669 ha; appendix 4) indicates that only 6\% of the total available area was affected by recurrent fire, and $8 \%$ of the available Big Sagebrush area was affected by recurrent fire. We cannot directly compare our values to those previously reported by Whisenant (1989) because that study does not report exactly what proportion of the Snake River Plain burned recurrently, only that "large areas" burned every 3-5 years. Finally, the percentage of fire area classified as recurrent was the highest for the Columbia Basin (34\%), potentially indicating an even greater risk of conversion to a grass-fire cycle than the Snake River Plain (with $25 \%$ of fire area classified as recurrent). 


\section{Fire Size}

Larger fires generally are considered to be of greater ecological concern, although the evidence supporting that conclusion is limited and varies among ecosystems (Keane and others, 2008). Historical fire sizes in sagebrush ecosystems are poorly understood. Some suggest that infrequent large fires were part of historical sagebrush fire regimes (Baker, 2011; Bukowski and Baker, 2013), although others suggest that the sizes of sagebrush fires during recent decades may be unprecedented (Keane and others, 2008). In terms of conservation efforts for the greater sage-grouse, it is arguably less important to know how current fire sizes compare to historical, than it is to understand how current fire sizes affect the species and its current remaining habitat.

One of the greatest concerns with large sagebrush fires is that, as fire size increases, so too does the dispersal distance that is required for seeds of non-resprouting native sagebrush species to reach ever-larger interiors of burned landscapes. Fire behavior in larger fires also may generate higher temperatures and more complete burning, leaving fewer patches of unburned vegetation that could otherwise serve as seed sources in the fire perimeter, thus further reducing capacity for recolonization of native species.

The higher proportions of larger fires that we report in the Northern Great Basin, Snake River Plain, and Southern Great Basin, and the increasing trend in fire area in the western region, are additional cause for concern. Miller and others (2011) also reported increasing fire size for the Southern Great Basin, but not for the other two regions. Baker (2013) did not analyze fire size directly, but did compare the top fire years in sagebrush vegetation types in the Western United States based on area burned among two consecutive 12-year periods (1985-1996, 1997-2008), and suggested that fire sizes may be increasing. Balch and others (2013) reported that a large proportion (39 of 50) of the largest fires that occurred in the Great Basin during 1980-2008 were associated with cheatgrass and, along with other evidence, they suggested this represented conversion to a grass/fire cycle in that region. Analysis of recent fire data across a broader array of ecosystem types also have suggested fire size has increased with time throughout most ecoregions of the Western United States (Dennison and others, 2014).

\section{Fire Rotation}

Fire rotation has great importance for the sustainability of sagebrush ecosystems, particularly if rotations are too short for sagebrush plants to regenerate and provide adequate habitat conditions for sage-grouse and other sagebrush-dependent species. Most sagebrush species generally are slow to recover after fire, due to limited seed dispersal, inability to resprout, and poor seed viability (Young and Evans, 1989; Miller and others, 2011). Thus, if fire rotations are too short (even without the influence of cheatgrass), many sagebrush stands would be unable to persist or to develop to mature stages (Lesica and others, 2007).

Estimates of historical fire rotation in sagebrush communities have varied widely, depending on community type, location, methods used, and assumptions made. Many previous studies focused on sagebrush-woodland ecotones, using fire-scarred trees to estimate fire return intervals for adjacent sagebrush stands. However, such estimates assume that fire behavior and history at these ecotones are consistent with those of broad expanses of shrubland and steppe that characterize sagebrush vegetation types. This assumption could result in biased fire rotation estimates that are uncharacteristic of most sagebrush communities. For instance, dated fire scars on trees that were used to estimate that fire rotation for mountain big sagebrush stands in Oregon were as short as 15 years or less (Miller and Rose, 1999), whereas a similar study suggested sagebrush fire rotations generally were decades or longer depending on biophysical conditions (Miller and Heyerdahl, 2008). Other studies have documented that at least a few to several decades are required for sagebrush ecosystems to recover after fire (for 
example, Welch and Criddle, 2003; Lesica and others, 2007), which would suggest even longer mean fire rotations are required to maintain a dominance of mature sagebrush communities on the broader landscape (Baker, 2006; Lesica and others, 2007). Supporting this notion, Bukowski and Baker (2013) used historical General Land Office Survey data from the late 1800s to early 1900s that documented fire evidence and vegetation types for large areas of the Western United States, and estimated that historical fire rotations were 171-342 and 137-217 years for Wyoming Big Sagebrush and Mountain Big Sagebrush, respectively.

Our estimates of modern rotations are not entirely comparable to other fire studies that focused on estimating modern rotations in sagebrush ecosystems. Estimates among studies vary, in part, due to differences in fire period (this study had a slightly longer temporal extent than other studies), geographic/vegetation delineations, vegetation datasets, and quantitative approaches used. For instance, our estimate of the modern fire rotation for Black/Low Sagebrush is 134 years for the Northern Great Basin, whereas Baker's (2013) estimates for Dwarf/Xeric Sagebrush and Low Sagebrush types (the most similar to our Low/Black Sagebrush type) in that region were 168 and 231 years, respectively. However, there also were similarities. Baker's (2013) estimate of modern fire rotation for Big Sagebrush Shrubland and Steppe in the Wyoming Basin and the Snake River Plain was very similar to our Big Sagebrush rotation estimates of 78 and 1,017 years in those two regions, respectively.

Despite these differences, the key issue is whether contemporary fire rotations for sagebrush communities are different from historical rotations, and whether differences between the two periods suggest rotations are either moving away from or are already outside of their historical ranges of variability. To make this assessment, we generally were hindered by a lack of historical fire rotation estimates for the different vegetation types among different regions. However, we can draw a few tentative conclusions based on estimates we do have of historical fire rotations for big sagebrush communities in different regions as presented in Baker (2013) and Bukowski and Baker (2013). For Big Sagebrush in the western region, our calculated modern fire rotations for all management zones (61-150 years across the entire region) likely represent a substantial reduction compared to historical fire rotations, which were estimated to be 171-342 (Bukowski and Baker, 2013). In contrast, the very long fire rotations (445-1,017 years) calculated for Big Sagebrush in the eastern region could suggest just the opposite trend, although credible historical fire rotation estimates for Big Sagebrush communities in this region are largely lacking. Black/Low Sagebrush fire rotations are more difficult to assess relative to historical rotation estimates. If compared to Baker's (2013) estimates for Dwarf/Xeric Sagebrush ecosystems, they are considerably shorter in the western region (potentially by a factor of 10 or greater), but they may be similar to historical fire rotations in the eastern region. However, this comparison is complicated by the disparities in vegetation types used between the two studies, as well as a paucity of empirically derived historical rotation estimates for low sagebrush in particular and sagebrush in the eastern region in general.

\section{Fire Season}

Fire season is a variable that is rarely analyzed in the scientific literature, partly because it has no standardized definition. However, a few studies have analyzed changes in large fire seasons over time across the Western United States. Westerling and others (2006) documented a trend toward longer fire seasons and earlier large fire start dates at higher elevations that were correlated with earlier spring snowmelt, while Dennison and others (2014) did not find significant trends in large fire start dates between 1984 and 2011 across large ecoregions of the Western United States. However, neither of these studies focused on data from sagebrush-dominated landscapes as we have here. 
In this study we define fire season as beginning with the first large fire ( $\geq 405 \mathrm{ha}$ ) and ending with the last large fire each year. Although this specific fire size is predetermined solely based on the reporting parameters of the MTBS program, we provide some evidence in the section "Methods" suggesting that fires above this general size may represent greater threats to the greater sage-grouse than do smaller fires (for example Coates and others, 2015). In addition, most of the annual area burned is due to large fires, and larger fires are thought to have greater ecological effects, especially for sagegrouse populations, as explained in the section, "Discussion" on fire size.

Fire seasons typically are reported in very broad terms, such as "summer-early fall" which was reported for sagebrush landscapes in northeastern California (Riegel and others, 2006) and peak fire season is reported as June-September throughout much of our study area (Littell and others, 2009; table 1). The beginning and ending dates that we reported occurred in May and June through September and October, and are fairly comparable to these previous studies, although those previous studies do not provide specific definitions for what constitute the beginning and ending of the fire season.

Changes in fire season lengths were significant for three of the management zones in this study, somewhat differing from the findings of Dennison and others (2014) which did not find a trend toward fires beginning earlier in the season, perhaps due to our more specific focus on sagebrush dominated landscapes. The increasing fire season length that we reported in the Southern Great Basin might be of primary concern, considering the relatively low resilience/resistance of that management zone. In contrast, increasing fire season length in the Great Plains may be considered a potential positive development, considering the apparent lack of fire compared to historical conditions, especially in Grassland vegetation of that management zone.

\section{Fire Threats Assessment for Greater Sage-Grouse Habitat}

Plants do not evolve in response to fire per se, but rather to the spatial and temporal patterns of fire, which are referred to as a fire regime (Pausas and Keeley, 2009). Some individual fire regime variables reported in this study may provide more information than others relative to the threats fire pose to vegetation. However, any single variable does not provide as much information as do all variables considered together.

We combined our various results of spatial and temporal patterns of fire reported in this study into an overall fire threats assessment. This assessment is focused on the implications of fire patterns on sage-grouse habitat, defined as vegetation types that contain sagebrush as a dominant or subdominant component. It is specifically related to landscape resilience to fire and resistance to annual grass invasion as inferred from soil temperature and moisture regimes (Campbell, 2014) and the general fire ecology literature. The assessment was not intended to specifically evaluate potential threats that fire may pose to greater sage-grouse population vital rates. That type of analysis ideally requires models linking direct and indirect effects of fire with demographic characteristics of greater sage-grouse populations linked through intermediate pathways (see Coates and others, 2015, for an example). Nevertheless, understanding the implications of fire patterns over the past 30 years on sagebrush habitat is clearly and important component of conservation plans for the greater sage-grouse. 
The fire threats assessment clearly indicates that threats are higher in the four western management zones than in the three eastern management zones (table 11), which are cause for concern in the western region of sage-grouse range. Among the four western zones, the Snake River Plain and the Columbia Basin ranked somewhat higher than the Southern Great Basin and Northern Great Basin in terms of their effects on sage-grouse habitat. Overall, our findings corroborate a recent demography study using a subset of same fire data in the western region of sage-grouse range and was published in parallel with the current report. Specifically, Coates and others (2015) studied annual patterns of wildfire, variation in precipitation, and soil conditions over 30 years to evaluate how these factors influence sage-grouse population vital growth rates using lek count data. The amount of area burned near sage-grouse leks, which is typically dominated by sagebrush communities, has adverse and longlasting effects on sage-grouse population growth. Importantly, fire near leks nullifies increases in population growth that are normally associated with periods of high precipitation. Thus, loss of sagebrush habitat through increasing wildfire, especially in low resilient and resistant systems as supported by our analysis, offer an explanation for long-term negative impacts of wildfire on sagegrouse populations. Their models also projected that approximately one-half of the current population of sage-grouse will remain in the Great Basin by the mid-2040s if current fire trends continue unabated. Collectively, this report and our findings clearly illustrate how sage-grouse habitat and their population persistence may be compromised as sagebrush ecosystems become more impacted by fire, and increasingly invaded by annual grasses, at least in the western portion of the species' range. Thus, the high rankings we report here for fire threats in the western region (table 11) support the previous high ranking of fire as a threat to the greater sage-grouse in that region (U.S. Fish and Wildlife Service, 2005). In contrast, considering the low rankings that we report for fire threats in the eastern region (table 11), it may be useful to reconsider the relative importance of wildfire as a threat to greater sagegrouse in those three management zones where it currently ranks among the top 5 of 19 total threats (U.S. Fish and Wildlife Service, 2005).

This threats assessment can be customized to include any subset of the multiple fire regime categories by simply adding them and recomparing the management zones. However, doing so in various combinations does not change the difference between the western and eastern regions, and only slightly changes differences among the western zones. Thus, we feel this threats assessment is a fairly robust summary of the overall implications of the fire patterns reported in this study. 
Table 11. Fire threats assessment on a scale from low to high (0-4) in nine regime categories.

[Ranking of amount of fire area and fire recurrence are based on both absolute values among management zones and relative values in each zone. Increasing annual amount, proportion, and length are each based on the one-tailed test of increasing trends during the 30-year study period. Deviation from historical is based on comparisons with the literature. Fire season length was not included in this assessment because there were no historical baselines to compare it with]

\begin{tabular}{|c|c|c|c|c|c|}
\hline $\begin{array}{l}\text { Management } \\
\text { Zone }\end{array}$ & $\begin{array}{c}\text { Fire area } \\
\text { (amount in } \\
\text { low resilience } \\
\text { /resistance areas) }\end{array}$ & $\begin{array}{c}\text { Fire area } \\
\text { (percentage of available in } \\
\text { low resilience/resistance } \\
\text { areas) }\end{array}$ & $\begin{array}{c}\text { Fire area } \\
\text { (increasing annual } \\
\text { amount in low } \\
\text { resilience/resistance } \\
\text { areas) }\end{array}$ & $\begin{array}{l}\text { Fire recurrence } \\
\text { (amount in low } \\
\text { resilience/resistance } \\
\text { areas) }\end{array}$ & $\begin{array}{l}\text { Fire recurrence } \\
\text { (percentage in low } \\
\text { resilience/resistance } \\
\text { areas) }\end{array}$ \\
\hline \multicolumn{6}{|c|}{ Western Region } \\
\hline Columbia Basin & 2 & 4 & 3 & 3 & 4 \\
\hline Northern Great Basin & 3 & 2 & 0 & 2 & 1 \\
\hline Snake River Plain & 4 & 3 & 4 & 4 & 3 \\
\hline Southern Great Basin & 3 & 2 & 0 & 2 & 2 \\
\hline \multicolumn{6}{|c|}{ Eastern Region } \\
\hline Colorado Plateau & 0 & 0 & 0 & 0 & 0 \\
\hline Great Plains & 0 & 1 & 0 & 0 & 1 \\
\hline Wyoming Basin & 1 & 0 & 0 & 0 & 0 \\
\hline \multicolumn{6}{|c|}{ Location of Information Used for Ranking } \\
\hline & $\begin{array}{r}\text { Tables 3, 7; Appendixes } \\
10,11\end{array}$ & $\begin{array}{r}\text { Tables 3, 7; Appendixes } \\
10,11\end{array}$ & $\begin{array}{r}\text { Figs. 6, 9; Appendixes } \\
10,11\end{array}$ & $\begin{array}{r}\text { Tables 4, 8; Appendixes } \\
10,11\end{array}$ & $\begin{array}{r}\text { Tables 4, 8; Appendixes } \\
10,11\end{array}$ \\
\hline
\end{tabular}




\begin{tabular}{|c|c|c|c|c|c|}
\hline & $\begin{array}{c}\text { Fire size } \\
\text { (higher proportion of } \\
\text { fire areas in larger fires) }\end{array}$ & $\begin{array}{c}\text { Fire size } \\
\text { (increasing proportion } \\
\text { of fire area in larger } \\
\text { fires) }\end{array}$ & $\begin{array}{l}\text { Fire rotation } \\
\text { (deviation from } \\
\text { historical) }\end{array}$ & $\begin{array}{l}\text { Fire season (increasing } \\
\text { annual length in low } \\
\text { resilience/resistance areas) }\end{array}$ & $\begin{array}{l}\text { Cumulative Fire } \\
\text { Threat Score }\end{array}$ \\
\hline \multicolumn{6}{|c|}{ Western Region } \\
\hline Columbia Basin & 1 & 4 & 4 & 0 & 25 \\
\hline Northern Great Basin & 4 & 4 & 2 & 0 & 18 \\
\hline Snake River Plain & 3 & 4 & 4 & 0 & 29 \\
\hline Southern Great Basin & 2 & 4 & 2 & 2 & 19 \\
\hline \multicolumn{6}{|c|}{ Eastern Region } \\
\hline Colorado Plateau & 0 & 0 & 0 & 0 & 0 \\
\hline Great Plains & 1 & 0 & 0 & 0 & 3 \\
\hline Wyoming Basin & 0 & 0 & 0 & 1 & 2 \\
\hline \multicolumn{6}{|c|}{ Location of Information Used for Ranking } \\
\hline & Figs. 6,11 & Figs. 8, 12 & Tables 5, 9 & $\begin{array}{l}\text { Figs. 8,11; Appendixes 10, } \\
\quad 11\end{array}$ & $\begin{array}{l}\text { sum of individual } \\
\text { categories }\end{array}$ \\
\hline
\end{tabular}




\section{Acknowledgments}

We thank M. Reeves, M. Rollins, and J. Yee who provided helpful reviews of earlier drafts of this report.

\section{References Cited}

Abatzoglou, J.T., and Kolden, C.A., 2013, Relationships between climate and macroscale area burned in the western United States: International Journal of Wildland Fire, v. 22, p. 1003-1020.

Agee, J., 1993, Fire ecology of Pacific Northwest forests: Washington, D.C., Island Press, 493 p.

Baker, W.L., 2006, Fire and restoration of sagebrush ecosystems: Wildlife Society Bulletin, no. 34, p. $177-185$.

Baker, W.L., 2009, Fire ecology in Rocky Mountain landscapes: Washington, D.C, Island Press, 632 p.

Baker, W.L., 2011, Pre-EuroAmerican and recent fire in sagebrush ecosystems, in Knick, S.T., and Connelly, J.W., eds., Ecology and conservation of greater sage-grouse-A landscape species and its habitats: Studies in Avian Biology, v. 38, p. 185-201.

Baker, W.L., 2013, Is wildland fire increasing in sagebrush landscapes of the western United States?, Annals of the Association of American Geographers, v. 103, issue 1, p. 5-19.

Balch, J.K., Bradley, B.A., D'Antonio, C.M., and Gómez-Dans, J., 2013, Introduced annual grass increases regional fire activity across the arid western USA (1980-2009): Global Change Biology, v. 19, p. 173-183.

Baruch-Mordo, S., Evans, J.S., Severson, J.P., Naugle, D.E., Maestas, J.D., Kiesecker, J.M., Falkowski, M.J., Hagen, C.A., and Reese, K.P., 2013, Saving sage-grouse from the trees-A proactive solution to reducing a key threat to a candidate species: Biological Conservation, v. 167, p. 233-241.

Benjamini, Y., and Yekutieli, D., 2001, The control of the false discovery rate in multiple testing under dependency: Annals of Statistics, v. 29, p. 1165-1188.

Blomberg, E.J., Sedinger, J.S., Atamian, M.T., and Nonne, D.V., 2012, Characteristics of climate and landscape disturbance influence the dynamics of greater sage-grouse populations: Ecosphere, v. 3, issue 6, article 55.

Bowman, D.M.J.S., MacDermott, H.J., Nichols, S.C., and Murphy, B.P., 2014, A grass-fire cycle eliminates an obligate-seeding tree in a tropical savanna: Ecology and Evolution, v. 4, p. 4184-4194.

Bradford, J.B., and Lauenroth, W.K., 2006, Controls over invasion of Bromus tectorum-The importance of climate, soil, disturbance and seed availability: Journal of Vegetation Science, v. 17, p. 693-704.

Bradley, B.A., 2009, Regional analysis of the impacts of climate change on cheatgrass invasion shows potential risk and opportunity: Global Change Biology, v. 15, p. 196-208.

Brooks, M.L., 2008, Plant invasions and fire regimes, in Zouhar, K., Kapler Smith, J. Sutherland, S., and Brooks, M.L., eds., Wildland fire in ecosystems - Fire and nonnative invasive plants: U.S. Department of Agriculture, Forest Service, Rocky Mountain Research Station, Ogden, Utah, RMRSGTR-42-volume 6, p. 33-46.

Brooks, M.L., Brown, C.S., Chambers, J.C., D’Antonio, C.M., Keeley, J.E., and Belnap J., in press, Exotic annual Bromus invasions - Comparisons among species and ecoregions in the Western United States, in Germino, M.J., Chambers, J.C., and Brown, C.S., eds., Exotic brome-grasses in arid and semi-arid ecosystems of the Western United States-Causes, consequences and management implications: Springer Press. 
Brooks, M.L., D'Antonio, C.M., Richardson, D.M., Grace, J.B., Keeley, J.E., DiTomaso, J.M., Hobbs, R.J., Pellant, M., and Pyke, D., 2004, Effects of invasive alien plants on fire regimes: Bioscience, $v$. 54, p. 677-688.

Brooks, M.L., and Pyke, D., 2001, Invasive plants and fire in the deserts of North America, in Galley, K., and Wilson, T., eds., Proceedings of the Invasive Species Workshop-The Role of Fire In the Control and Spread of Invasive Species. Fire Conference 2000-The First National Congress on Fire Ecology, Prevention, and Management, Miscellaneous Publications No. 11, Tall Timbers Research Station, Tallahassee, Florida, p. 1-14.

Bukowski, B.E., and Baker, W.L., 2013, Historical fire regimes, reconstructed from land-survey data, led to complexity and fluctuation in sagebrush landscapes: Ecological Applications, v. 23, p. 546564.

Bunting, S.C., Kilgore, B.M., and Bushey, C.L., 1987, Guidelines for prescribed burning sagebrushgrass rangelands in the northern Great Basin: U.S. Department of Agriculture, Forest Service, Intermountain Research Station, Ogden, Utah, General Technical Report INT-231, 33 p.

Campbell, S.B., 2014, Soil temperature and moisture regime data for the range of greater sage-grouseData product: USDA Natural Resources Conservation Service, Portland, Oregon, Web site, accessed February 2, 2015, at https://www.sciencebase.gov/catalog/folder/537f8be5e4b021317a872f1b?community=LC+MAP++ Landscape+Conservation+Management+and+Analysis+Portal.

Casazza, M.L., Coates, P.S., and Overton, C.T., 2011, Linking habitat selection and brood success in greater sage-grouse, in Sandercock, B.K., Martin, K., and Segelbacher, G., eds., Ecology, conservation, and management of grouse-Studies in avian biology (no. 39): Berkeley, University of California Press, p. 151-167.

Chambers, J.C., 2008, Fire and the Great Basin. in Chambers, J. C., Devoe, N., and Evenden, A., eds., Collaborative management and research in the Great Basin-Examining the issues and developing a framework for action: U.S. Department of Agriculture, Forest Service, Rocky Mountain Research Station, Fort Collins, Colorado, General Technical Report RMRS-GTR-204, p. 33-37.

Chambers, J.C., Bradley, B.A., Brown, C.S., D’Antonio, C., Germino, M.J., Grace, J.B., Hardegree, S.P., Miller, R.F., and Pyke, D.A., 2014a, Resilience to stress and disturbance, and resistance to Bromus tectorum L. invasion in cold desert shrublands of western North America: Ecosystems, v. 17, no. 2, p. 360-375.

Chambers, J.C., Pyke, D.A., Maestas, J.D., Pellant, M., Boyd, C.S., Campbell, S.B., Espinosa, S., Havlina, D.W., Mayer, K.E., and Wuenschel, A., 2014b, Using resistance and resilience concepts to reduce impacts of invasive annual grasses and altered fire regimes on the sagebrush ecosystem and greater sage-grouse - A strategic multi-scale approach: U.S. Department of Agriculture, Forest Service, Rocky Mountain Research Station, Fort Collins, Colorado, General Technical Report RMRSGTR-326, 73 p.

Chambers, J.C., Roundy, B.A., Blank, R.R., Meyer, S.E., and Whittaker, A., 2007, What makes Great Basin sagebrush ecosystems invasible by Bromus tectorum? Ecological Monographs, v. 77, no. 1, p. 117145.

Coates, P.S., Ricca, M.A., Prochazka, B.G., Doherty, K.E., Brooks, M.L., and Casazza, M.L., 2015, Long-term effects of wildfire on greater sage-grouse-Integrating population and ecosystem concepts for management in the Great Basin: U.S. Geological Survey Open-File Report 2015-1165, 42 p., http://dx.doi.org/10.3133/ofr20151165.

Connelly, J.W., Reese, K.P., Fischer, R.A., and Wakkinen, W.L., 2000, Response of a sage grouse breeding population to fire in southeastern Idaho: Wildlife Society Bulletin, v. 28, p. 90-96. 
Connelly, J.W., Knick, S.T., Schroeder, M.A., and Stiver, S.J., 2004, Conservation assessment of greater sage-grouse and sagebrush habitats: Western Association of Fish and Wildlife Agencies, Cheyenne, Wyoming, http://sagemap.wr.usgs.gov/docs/Greater_Sage-

grouse_Conservation_Assessment_060404.pdf.

D'Antonio, C.M., and Vitousek, P.M., 1992, Biological invasions by exotic grasses, the grass/fire cycle, and global change: Annual Review of Ecology and Systematics, v. 23, p. 63-87.

Davis, D.M., and Crawford, J.A. 2015, Case study: Short-term response of greater sage-grouse habitats to wildfire in mountain big sagebrush communities: Wildlife Society Bulletin, v. 39, issue 1, p. 129-137.

Dennison, P.E., Brewer, S.C., Arnold, J.D., and Moritz, M.A., 2014, Large wildfire trends in the western United States, 1984-2011, Geophysical Research Letters, v. 41, doi:10.1002/2014GL059576.

Eidenshink, J., Schwind, B., Brewer, K., Zhu, Z., Quayle, B., and Howard, S., 2007, A project for monitoring trends in burn severity: Fire Ecology, v. 3, p. 3-21.

Fischer, R.A., Reese, K.P., and Connelly, J.W., 1996, An investigation on fire effects within xeric sage grouse brood habitat: Journal of Range Management, v. 49, p. 194-198.

Fischer, R.A., Wakkinen, W.L., Reese, K.P., and Connelly, J.W., 1997, Effects of prescribed fire on movements of female sage grouse from breeding to summer ranges: The Wilson Bulletin, v. 109, p. 82-91.

Interagency Greater Sage-Grouse Disturbance and Monitoring Subteam, 2014, The greater sage-grouse monitoring framework: Bureau of Land Management and U.S. Forest Service, 47 p., https://eplanning.blm.gov/epl-front-office/projects/lup/21152/48421/52584/GRSG-FINALMonitoring Framework 20140530.pdf.

Hanser, S.E., and Manier, D.J., 2013, Greater Sage-Grouse National Research Strategy: U.S. Geological Survey Scientific Investigations Report 2013-5167, 46 p. plus appendix.

Jolly, W.M., Cochrane, M.A., Freeborn, P.H., Holden, Z.A., Brown, T.J., Williamson, G.J., and Bowman, D.M.J.S., 2015, Climate-induced variations in global wildfire danger from 1979 to 2013: Nature Communications, v. 6, no. 7537, 11 p.

Keane, R.E., Agee, J.K., Fule, P., Keeley, J.E., Key, C., Kitchen, S.G., Miller, R., and Schulte, L.A., 2008, Ecological effects of large fires on US landscapes-Benefit or catastrophe?: International Journal of Wildand Fire, v. 17, p. 696-712.

Kendall, M.G., 1975, Rank correlation methods (4th ed.): London, Charles Griffin Publishers.

Knick, S.T., and Connelly, J.W., eds., 2011, Greater sage-grouse-Ecology and conservation of a landscape species and its habitats-Studies in avian biology (no. 38): Berkeley, University of California Press, 664 p.

Knick, S.T., Hanser, S.E., and Preston, K.L., 2013, Modeling ecological minimum requirements for distribution of greater sage-grouse leks-Implications for population connectivity across their western range, U.S.A: Ecology and Evolution, v. 3, no. 6, p. 1539-1551.

Knick, S.T., and Rotenberry, J.T., 1997, Landscape characteristics of disturbed shrubsteppe habitats in southwestern Idaho (U.S.A.): Landscape Ecology, v. 12, p. 287-297.

Lesica, P., Cooper, S.V., and Kudray, G., 2007, Recovery of big sagebrush following fire in southwest Montana: Rangeland Ecology and Management, v. 60, p. 261-269.

Littell, J.S., McKenzie, D., Peterson, D.L., and Westerling, A.L., 2009, Climate and wildfire area burned in western U.S. ecoprovinces, 1916-2003: Ecological Applications, v. 19, p. 1003-1021. Mann, H.B., 1945, Non-parametric tests against trend: Econometrica, v. 13, p. 163-171. 
Menakis, J.P., Osborne, D., and Miller, M., 2003, Mapping the cheatgrass-caused departure from historical natural fire regimes in the Great Basin, USA, in Proceedings, Fire, Fuel Treatments, and Ecological Restoration Conference, April 16-18, 2002, Fort Collins, Colorado: USDA Forest Service, Rocky Mountain Research Station online publication RMRS-P-29.

Meyer, S.E., Garvin, S.C., and Beckstead, J., 2001, Factors mediating cheatgrass invasion of intact salt desert shrubland, in McArthur, D.E., and Fairbanks, D.J., compilers, Proceedings-Shrubland ecosystem genetics and biodiversity: Proceedings RMRS-P-21, Ogden UT, U.S. Department of Agriculture, Forest Service, Rocky Mountain Research Station, p. 224-232.

Miller, R.F., and Eddleman, L.L., 2001, Spatial and temporal changes of sage grouse habitat in the sagebrush biome: Oregon State University, Agricultural Experiment Station, Technical Bulletin 151, $35 \mathrm{p}$.

Miller, R.F., and Heyerdahl, E.K., 2008, Fine-scale variation of historical fire regimes in sagebrushsteppe and juniper woodland-An example from California, USA: International Journal of Wildland Fire, v. 17, p. 245-254.

Miller, R.F., Knick, S.T., Pyke, D.A., Meinke, C.W., Hanser, S.E., Wisdom, M.J., and Hild, A.L., 2011, Characteristics of sagebrush habitats and limitations to long-term conservation, in Knick, S.T., and Connelly, J.W., eds., Greater sage-grouse-Ecology and conservation of a landscape species and its habitats: Berkeley, University of California Press, p. 145-184.

Miller, R.F., and Rose, J.A., 1999, Fire history and western juniper encroachment in sagebrush steppe: Journal of Range Management, v. 52, p. 550-559.

Miller, R.F., and Tausch, R.J., 2001, The role of fire in pinyon and juniper woodlands-A descriptive analysis, in Galley, K.E.M., and Wilson, T.P., eds., Proceedings of the Invasive Species WorkshopThe Role of Fire in the Control and Spread of Invasive Species: Fire Conference 2000-The First National Congress on Fire Ecology, Prevention, and Management, Miscellaneous Publication No. 11, Tall Timbers Research Station, Tallahassee, Florida, p. 15-30.

Nelle, P.J., Reese, K.P., and Connelly, J.W., 2000, Long-term effects of fire on sage-grouse habitat: Journal of Range Management, v. 53, p. 586-591.

Pausas, J.G., and Keeley, J.E., 2009, A burning story-The role of fire in the history of life: Bioscience, v. 59, p. 593-601.

Pedersen, E.K., Connelly, J.W., Hendrickson, J.R., and Grant, W.E., 2003, Effect of sheep grazing and fire on sage grouse populations in southeastern Idaho: Ecological Modelling, v. 165. p. 23-47.

Ratajczak, Z., Nippert, J.B., Briggs, J.M., and Blair, J.M., 2014, Fire dynamics distinguish grasslands, shrublands, and woodlands as alternative attractors in the Central Great Plains of North America: Journal of Ecology, v. 102, p. 1374-1385.

Rhodes, E.C., Bates, J.D., Sharp, R.N., and Davies, K.W., 2010, Fire effects on cover and dietary resources of sage-grouse habitat: Journal of Wildlife Management, v. 74, p. 755-764. 
Rice, P.M., McPherson, G.R., and Rew, L.J., 2001, Fire and nonnative invasive plants in the Interior West Bioregion, in Zouhar, K., Smith, J.K., Sutherland, S., and Brooks, M.L., eds., Wildland fire in ecosystems: fire and nonnative invasive plants. Fort Collins, CO, USA: US Department of Agriculture, Forest Service, Rocky Mountain Research Station, General Technical Report, RMRSGTR-42, v. 6. p. 141-171.

Riegel, G.M., Miller, R.F., Skinner, C.N., and Smith, S.E., 2006, Northeastern plateaus bioregion, in Sugihara, N.G., van Wagtendonk, J.W., Shaffer, K.E., Fites-Kaufman, J., and Thode, A.E., eds., Fire in California's ecosystem: Berkeley and Los Angeles, University of California Press.

Rollins, M.G., 2009, LANDFIRE-A nationally consistent vegetation, wildland fire, and fuel assessment: International Journal of Wildland Fire, v. 18, p. 235-249.

Rossiter, N.A., Setterfield, S.A., Douglas, M.M., and Huntley, L.B., 2003, Testing the grass-fire cycleAlien grass invasion in the tropical savannas of northern Australia: Diversity and Distributions, v. 9, p. 160-176.

Rowland, M.M., Wisdom, M.J., Suring, L.H., and Meinke, C.W., 2006, Greater sage-grouse as an umbrella species for sagebrush-associated vertebrates: Biological Conservation, v. 129, p. 323-335.

Schroeder, M.A., Aldridge, C.L., Apa, A.D., Bohne, J.R., Braun, C.E., Bunnell, S.D., Connelly, J.W., Deibert, P.A., Gardner, S.C., Hilliard, M.A., Kobriger, G.D., McAdam, S.M., McCarthy, C.W., McCarthy, J.J., Mitchell, D.L., Rickerson, E.V., and Stiver, S.J., 2004, Distribution of sage-grouse in North America: The Condor, v. 106, p. 363-376.

Setterfield, S.A., Rossiter-Rachor, N.A., Douglas, M.M., Wainger, L., Petty, A.M., Barrow, P., Shepherd, I.J., and Ferdinands, K.B., 2013, Adding fuel to the fire-The impacts of non-native grass invasion on fire management at a regional scale: PLoS ONE, v. 8, no. 5, e59144, doi:10.1371/journal.pone.0059144.

Sparks, A., Boschetti, L., Smith, A., Tinkham, W., Lannom, K., and Newingham, B., 2014, An accuracy assessment of the MTBS burned area product for shrub-steppe fires in the northern Great Basin, United States: International Journal of Wildland Fire, v. 24, no. 1, p. 70-78.

Stiver, S.J., Apa, A.D., Bohne, J.R., Bunnell, S.D., Deibert, P.A., Gardner, S.C., Hilliard, M.A., McCarthy, C.W., and Schroeder, M.A., 2006, Greater sage-grouse comprehensive conservation strategy: Cheyenne, Wyoming, Western Association of Fish and Wildlife Agencies, 442 p., http://wdfw.wa.gov/publications/01317/wdfw01317.pdf.

Strand, E.K., Bunting, S.C., and Keefe, R.F., 2013, Influence of wildland fire along a successional gradient in sagebrush steppe and western juniper woodlands: Rangeland Ecology and Management, $\mathrm{v}$. 66, p. 667-679.

Sugihara, N.G., van Wagtendonk, J.W., and Fites-Kaufman, J., 2006, Fire as an ecological process, in Sugihara, N.G., van Wagtendonk, J.W., Shaffer, K.E., Fites-Kaufman, J., and Thode, A.E., eds., Fire in California's ecosystem: Berkeley and Los Angeles, University of California Press.

U.S. Department of the Interior, 2015a, Secretarial Order 3336-Rangeland Fire Prevention, Management, and Restoration, accessed August 2015, at http://www.fws.gov/greatersagegrouse/documents/Threats/20150106DOI-Fire-Order.pdf. 
U.S. Department of the Interior, 2015b, An integrated rangeland fire management strategy—Final report to the Secretary of the Interior: Rangeland Fire Task Force, 82 p., http://forestsandrangelands.gov/rangeland/.

U.S. Fish and Wildlife Service, 2005, Endangered and threatened wildlife and plants; 12-month finding for petitions to list the greater sage-grouse as threatened or endangered: Federal Register, v. 70, p. 2244-2282, accessed August 2015, at https://www.federalregister.gov/articles/2005/01/12/05583/endangered-and-threatened-wildlife-and-plants-12-month-finding-for-petitions-to-list-the-greater.

U.S. Fish and Wildlife Service, 2010, Endangered and threatened wildlife and plants; 12-month findings for petitions to list the greater sage-grouse (Centrocercus urophasianus) as threatened or endangered: Federal Register, v. 75, no. 55, p. 13909-14014, accessed August 2015, at https://www.federalregister.gov/articles/2010/03/23/2010-5132/endangered-and-threatened-wildlifeand-plants-12-month-findings-for-petitions-to-list-the-greater.

Young, J.A., and Evans, R.A., 1989, Dispersal and germination of big sagebrush (Artemisia 319 tridentata) seeds: Weed Science, v. 37, p. 201-206.

Welch, B.L., and Criddle, C., 2003, Countering misinformation concerning big sagebrush, USDA Forest Service, Rocky Mountain Research Station, Fort Collins, Colorado, Research Paper RMRS-RP-40, $28 \mathrm{p}$.

Westerling, A.L., Hidalgo, H.G., Cayan, D.R., and Swetnam, T.W., 2006, Warming and earlier spring increase Western U.S. forest wildfire activity: Science, v. 313, p. 940-943.

Whisenant, S.G., 1989, Changing fire frequencies on Idaho's Snake River Plains-Ecological and management implications, in McArthur, E.D., Romney, E.M., Smith, S.D., and Tueller, P.T., compilers, Proceedings-Symposium on Cheatgrass Invasion, Shrub Die-Off, and Other Aspects of Shrub Biology and Management: USDA Forest Service, Intermountain Research Station, Ogden, Utah, General Technical Report INT-276, p. 4-10.

White, R.S., and Currie, P.O., 1983, The effects of prescribed burning on silver sagebrush: Journal of Range Management, v. 36, p. 611-613.

Wilken, E., Nava, F.J., and Griffith, G., 2011, North American terrestrial ecoregions-Level III: Montreal, Canada, Commission for Environmental Cooperation. 


\section{Appendix 1. Crosswalk of Greater Sage-Grouse Management Zones with Other Bioregional Classifications}

[Floristic Province: Miller and Eddleman (2001); http://greatbasin.wr.usgs.gov/LWG/Floristic_Provinces.asp accessed March 16, 2015. Level III Ecoregions: Wilken and others (2011)]

\begin{tabular}{lll}
\hline \multicolumn{1}{c}{ Management Zone } & \multicolumn{1}{c}{ Floristic Province } & \multicolumn{1}{c}{ Level III Ecoregion(s) } \\
\hline Columbia Basin & \multicolumn{1}{c}{ Western Management Zones } \\
Northern Great Basin & Columbia Basin & Columbia Plateau 10.1.2 \\
Snake River Plain & Northern Great Basin & Northern Basin and Range 10.1.3 \\
& Snake River Plain & Snake River Plain 10.1.8, \\
Southern Great Basin & Southern Great Basin & Northern Basin and Range 10.1.3 \\
Colorado Plateau & Colorado Plateau & Central Basin and Range 10.1.5 \\
\hline \multicolumn{2}{c}{ Western Management Zones } \\
\hline Great Plains & \multicolumn{2}{c}{ Colorado Plateaus 10.1.6 } \\
Wyoming Basin & Silver Sagebrush Subdivision & Northwestern Great Plains 9.3.3, \\
& Wyoming Basin & Northwestern Glaciated Plains 9.3.1 \\
& & Wyoming Basin 10.1.4 \\
\hline
\end{tabular}


Appendix 2. Proportion of Land Ownership in the Greater Sage-Grouse Management Zones

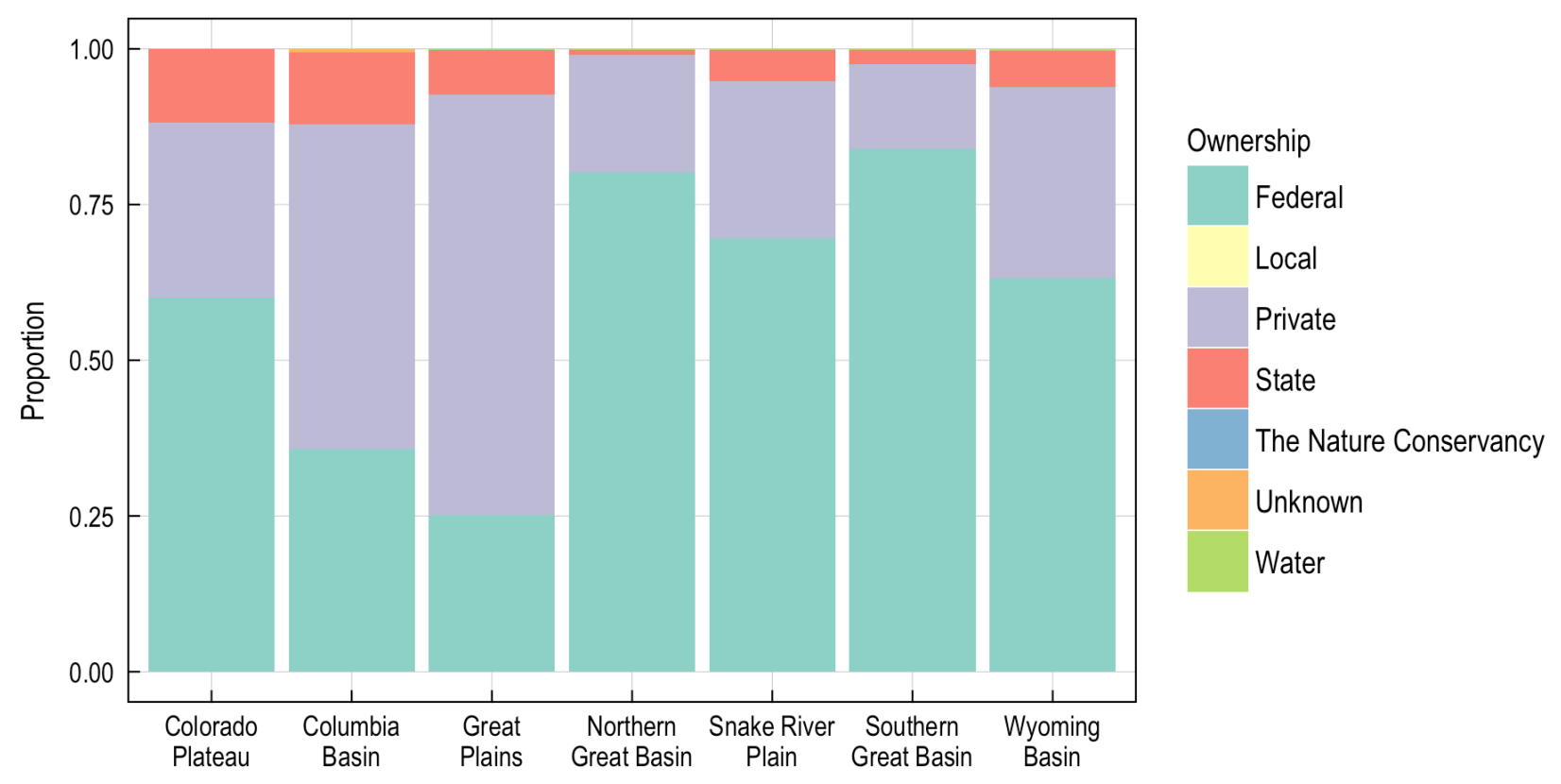




\section{Appendix 3. Soil Temperature and Moisture Regimes in the Study Area}

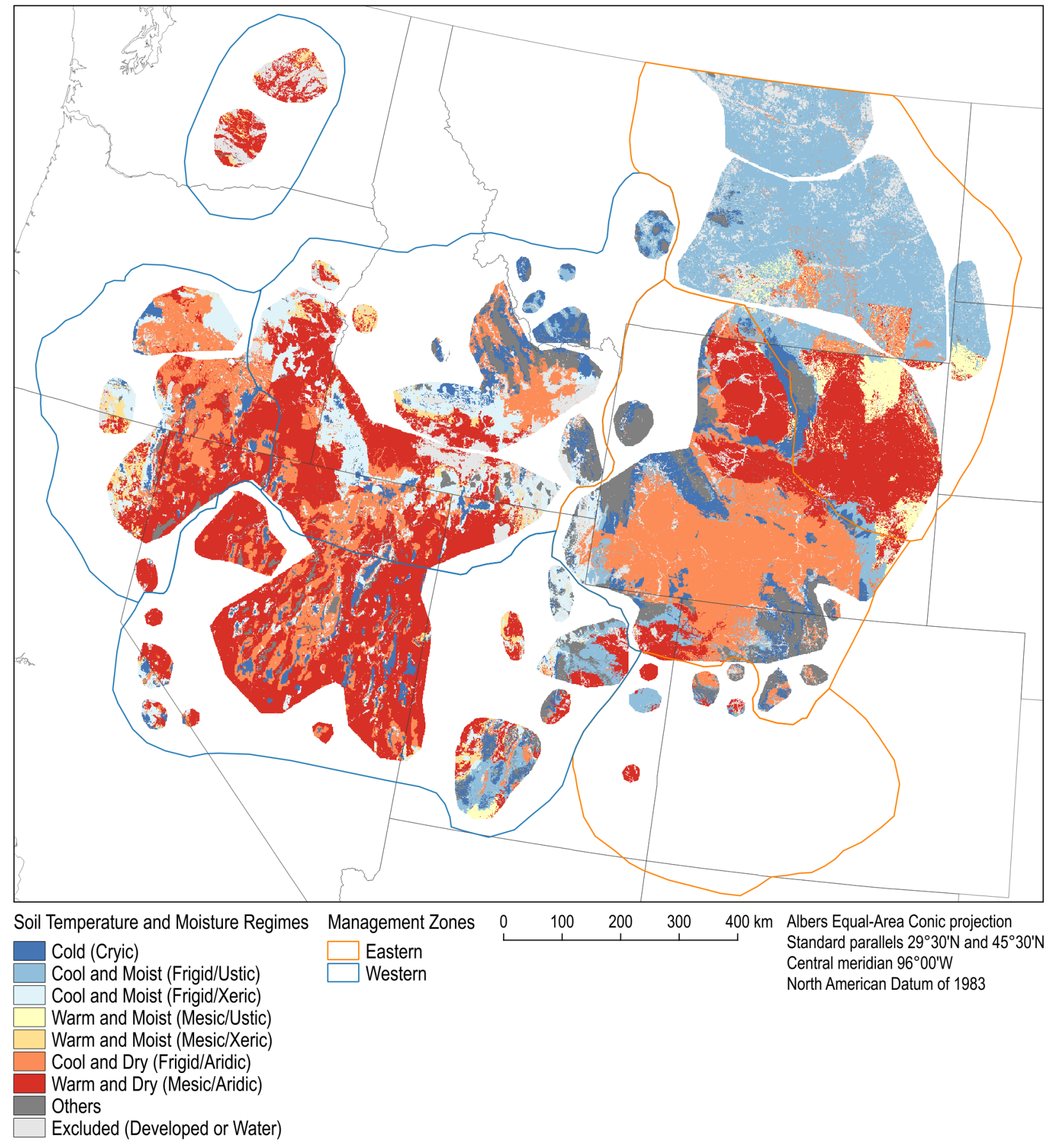




\section{Appendix 4. Aerial Extent of the Major Vegetation Types in the Four Western Management Zones and}

Their Constituent LANDFIRE Biophysical Setting Types That Were Previously Identified as Capable of Supporting Sagebrush Vegetation and Providing Suitable Seasonal Habitat for Greater Sage-Grouse in the Greater Sage-Grouse Monitoring Framework

[From Interagency Greater Sage-Grouse Disturbance and Monitoring Subteam (2014, table 4). The first two vegetation types are predominantly sagebrush, whereas the latter four are pre-dominantly other plant taxa. All six differ in terms of floristics, fire regimes, and as potential habitat for the greater sage-grouse. The Non-Sagebrush type does not contain any sagebrush species as a potential dominant in the constituent biophysical settings descriptions and were not previously identified as supporting sagebrush vegetation or greater sage-grouse habitat]

\begin{tabular}{|c|c|c|c|c|c|}
\hline \multirow[b]{2}{*}{ Biophysical Setting } & \multicolumn{5}{|c|}{ Area (hectares) } \\
\hline & Columbia Basin & $\begin{array}{l}\text { Northern Great } \\
\text { Basin }\end{array}$ & $\begin{array}{l}\text { Snake River } \\
\text { Plain }\end{array}$ & $\begin{array}{l}\text { Southern Great } \\
\text { Basin }\end{array}$ & $\begin{array}{c}\text { Western } \\
\text { Management } \\
\text { Zones } \\
\text { Combined }\end{array}$ \\
\hline \multicolumn{6}{|c|}{ Big Sagebrush } \\
\hline Inter-Mountain Basins Big Sagebrush Steppe & 122,974 & $2,002,658$ & $5,529,428$ & 38,133 & $7,693,192$ \\
\hline $\begin{array}{l}\text { Inter-Mountain Basins Big Sagebrush Shrubland - Wyoming } \\
\text { Big Sagebrush }\end{array}$ & 0 & 0 & 1,124 & 0 & 1,124 \\
\hline Inter-Mountain Basins Montane Sagebrush Steppe & 19,374 & 916,680 & $2,958,342$ & 751,474 & $4,645,870$ \\
\hline Inter-Mountain Basins Big Sagebrush Shrubland & 2,594 & 407,808 & 970,249 & $3,078,812$ & $4,459,463$ \\
\hline $\begin{array}{l}\text { Inter-Mountain Basins Big Sagebrush Shrubland - Basin Big } \\
\text { Sagebrush }\end{array}$ & 0 & 0 & 1,331 & 0 & 1,331 \\
\hline $\begin{array}{l}\text { Inter-Mountain Basins Montane Sagebrush Steppe - Mountain } \\
\text { Big Sagebrush }\end{array}$ & 0 & 0 & 2,437 & 545,987 & 548,425 \\
\hline \multicolumn{6}{|c|}{ Black/Low Sagebrush } \\
\hline Great Basin Xeric Mixed Sagebrush Shrubland & 0 & $1,564,488$ & $2,531,070$ & $2,860,024$ & $6,955,582$ \\
\hline Columbia Plateau Low Sagebrush Steppe & 314 & 107,706 & 124,439 & 12,454 & 244,913 \\
\hline $\begin{array}{l}\text { Inter-Mountain Basins Montane Sagebrush Steppe - Low } \\
\text { Sagebrush }\end{array}$ & 0 & 0 & 13 & 147,431 & 147,444 \\
\hline Colorado Plateau Mixed Low Sagebrush Shrubland & 0 & 0 & 4 & 60,500 & 60,505 \\
\hline Wyoming Basins Dwarf Sagebrush Shrubland and Steppe & 0 & 0 & 0 & 0 & 0 \\
\hline \multicolumn{6}{|c|}{ Desert Mixed Shrub } \\
\hline Inter-Mountain Basins Mixed Salt Desert Scrub & 0 & 251,235 & 447,578 & $1,800,540$ & $2,499,353$ \\
\hline Columbia Plateau Scabland Shrubland & 105,944 & 38,562 & 22,297 & 0 & 166,803 \\
\hline
\end{tabular}




\begin{tabular}{|c|c|c|c|c|c|}
\hline \multirow[b]{2}{*}{ Biophysical Setting } & \multicolumn{5}{|c|}{ Area (hectares) } \\
\hline & Columbia Basin & $\begin{array}{l}\text { Northern Great } \\
\text { Basin }\end{array}$ & $\begin{array}{l}\text { Snake River } \\
\text { Plain }\end{array}$ & $\begin{array}{l}\text { Southern Great } \\
\text { Basin }\end{array}$ & $\begin{array}{c}\text { Western } \\
\text { Management } \\
\text { Zones } \\
\text { Combined }\end{array}$ \\
\hline Inter-Mountain Basins Semi-Desert Shrub-Steppe & 4 & 7,755 & 20,815 & 59,491 & 88,064 \\
\hline \multicolumn{6}{|c|}{ Floodplain } \\
\hline Western Great Plains Floodplain Systems & & 0 & 41 & 0 & 41 \\
\hline \multicolumn{6}{|c|}{ Grassland } \\
\hline Northwestern Great Plains Mixed Grass Prairie & 0 & 0 & 183 & 0 & 183 \\
\hline Northwestern Great Plains Shrubland & 0 & 0 & 705 & 0 & 705 \\
\hline Columbia Plateau Steppe and Grassland & 540,127 & 189,684 & 79,839 & 0 & 809,650 \\
\hline Western Great Plains Sand Prairie & 0 & 0 & 0 & 0 & 0 \\
\hline \multicolumn{6}{|c|}{ Mountain Brush } \\
\hline $\begin{array}{l}\text { Inter-Mountain Basins Curl-leaf Mountain Mahogany } \\
\text { Woodland and Shrubland }\end{array}$ & 26 & 40,836 & 111,101 & 330,203 & 482,166 \\
\hline Rocky Mountain Gambel Oak-Mixed Montane Shrubland & 0 & 0 & 34 & 11,996 & 12,030 \\
\hline Rocky Mountain Lower Montane-Foothill Shrubland & 0 & 0 & 20,576 & 33,091 & 53,667 \\
\hline \multicolumn{6}{|c|}{ Non-Sagebrush } \\
\hline remaining biophysical setting types combined & 115,513 & $2,202,923$ & $3,675,063$ & $4,785,702$ & $10,779,201$ \\
\hline
\end{tabular}




\section{Appendix 5. Aerial Extent of the Major Vegetation Types in the Three Eastern Management Zones and Their Constituent LANDFIRE Biophysical Setting Types That Were Previously Identified as Capable of Supporting Sagebrush Vegetation and Providing Suitable Seasonal Habitat for Greater Sage-Grouse in the Greater Sage-Grouse Monitoring Framework.}

[From Interagency Greater Sage-Grouse Disturbance and Monitoring Subteam (2014, table 4). The first two vegetation types are predominantly sagebrush, whereas the latter four are pre-dominantly other plant taxa. All six differ in terms of floristics, fire regimes, and as potential habitat for the greater sage-grouse. The Non-Sagebrush type does not contain any sagebrush species as a potential dominant in the constituent biophysical settings descriptions and were not previously identified as supporting sagebrush vegetation or greater sage-grouse habitat]

\begin{tabular}{|c|c|c|c|c|}
\hline \multirow[b]{2}{*}{ Biophysical Setting } & \multicolumn{4}{|c|}{ Area (hectares) } \\
\hline & Colorado Plateau & Great Plains & Wyoming Basin & $\begin{array}{c}\text { Eastern } \\
\text { Management } \\
\text { Zones Combined }\end{array}$ \\
\hline \multicolumn{5}{|c|}{ Big Sagebrush } \\
\hline Inter-Mountain Basins Big Sagebrush Steppe & 25,365 & $2,583,626$ & 165,868 & $2,774,859$ \\
\hline $\begin{array}{l}\text { Inter-Mountain Basins Big Sagebrush Shrubland - Wyoming Big } \\
\text { Sagebrush }\end{array}$ & 0 & 69,807 & $7,825,217$ & $7,895,024$ \\
\hline Inter-Mountain Basins Montane Sagebrush Steppe & 963 & 188,443 & $1,913,463$ & $2,102,869$ \\
\hline Inter-Mountain Basins Big Sagebrush Shrubland & 66,914 & 350 & 614,627 & 681,892 \\
\hline Inter-Mountain Basins Big Sagebrush Shrubland - Basin Big Sagebrush & 0 & 763 & 632,059 & 632,822 \\
\hline $\begin{array}{l}\text { Inter-Mountain Basins Montane Sagebrush Steppe - Mountain Big } \\
\text { Sagebrush }\end{array}$ & 22,703 & 0 & 300,556 & 323,259 \\
\hline \multicolumn{5}{|c|}{ Black/Low Sagebrush } \\
\hline Colorado Plateau Mixed Low Sagebrush Shrubland & 14,085 & 0 & 14,986 & 29,071 \\
\hline Columbia Plateau Low Sagebrush Steppe & 0 & 0 & 1,336 & 1,336 \\
\hline Great Basin Xeric Mixed Sagebrush Shrubland & 0 & 0 & 12 & 12 \\
\hline Inter-Mountain Basins Montane Sagebrush Steppe - Low Sagebrush & 130 & 0 & 12,868 & 12,999 \\
\hline Wyoming Basins Dwarf Sagebrush Shrubland and Steppe & 0 & 1,464 & 2,819 & 4,282 \\
\hline \multicolumn{5}{|c|}{ Desert Mixed Shrub } \\
\hline Inter-Mountain Basins Mixed Salt Desert Scrub & 28,054 & 17 & 0 & 28,070 \\
\hline Columbia Plateau Scabland Shrubland & 0 & 0 & 199,057 & 199,057 \\
\hline Inter-Mountain Basins Semi-Desert Shrub-Steppe & 84 & 22 & 7,330 & 7,436 \\
\hline
\end{tabular}




\begin{tabular}{|c|c|c|c|c|}
\hline \multirow[b]{2}{*}{ Biophysical Setting } & \multicolumn{4}{|c|}{ Area (hectares) } \\
\hline & Colorado Plateau & Great Plains & Wyoming Basin & $\begin{array}{c}\text { Eastern } \\
\text { Management } \\
\text { Zones Combined }\end{array}$ \\
\hline \multicolumn{5}{|c|}{ Floodplain } \\
\hline Western Great Plains Floodplain Systems & 0 & 828,117 & 64,886 & 893,003 \\
\hline \multicolumn{5}{|c|}{ Grassland } \\
\hline Northwestern Great Plains Mixed Grass Prairie & 0 & $12,440,726$ & 344,383 & $12,785,109$ \\
\hline Northwestern Great Plains Shrubland & 0 & $1,000,166$ & 3,798 & $1,003,965$ \\
\hline Columbia Plateau Steppe and Grassland & 0 & 0 & 0 & 0 \\
\hline Western Great Plains Sand Prairie & 0 & 183,137 & 10,984 & 194,122 \\
\hline \multicolumn{5}{|c|}{ Mountain Brush } \\
\hline $\begin{array}{l}\text { Inter-Mountain Basins Curl-leaf Mountain Mahogany Woodland and } \\
\text { Shrubland }\end{array}$ & 918 & 11,046 & 23,535 & 35,500 \\
\hline Rocky Mountain Gambel Oak-Mixed Montane Shrubland & 143,034 & 0 & 246,919 & 389,953 \\
\hline Rocky Mountain Lower Montane-Foothill Shrubland & 6,811 & 18,763 & 61,718 & 87,292 \\
\hline \multicolumn{5}{|c|}{ Non-Sagebrush } \\
\hline remaining biophysical setting types combined & 382,977 & $2,213,457$ & $4,980,614$ & $7,577,048$ \\
\hline
\end{tabular}




\section{Appendix 6. Crosswalk of Soil Temperature and Moisture Regimes with Potential Resilience to Fire and Resistance to Annual Grass Invasion}

[Temperature and moisture regime class: From Campbell (2014). Potential resilience and resistance gradient: Derived from information in Meyer and others, 2001; Bradford and Lauenroth, 2006; Chambers and others, 2007, 2014a, 2014b; and Bradley, 2009]

\begin{tabular}{llc}
\hline \multicolumn{1}{c}{ Common name } & $\begin{array}{c}\text { Temperature and moisture } \\
\text { regime class }\end{array}$ & $\begin{array}{c}\text { Potential resilience and } \\
\text { resistance gradient }\end{array}$ \\
\hline Cold & Cryic & highest \\
Cool and Moist (summer) & Frigid/Ustic & intermediate \\
Cool and Moist (winter) & Frigid/Xeric & intermediate \\
Warm and Moist (summer) & Mesic/Ustic & intermediate \\
Warm and Moist (winter) & Mesic/Xeric & intermediate \\
Cool and Dry & Frigid/Aridic & intermediate \\
Warm and Dry & Mesic/Aridic & lowest \\
\hline
\end{tabular}




\section{Appendix 7. Proportions of Total Available Area Represented by Each Soil Temperature and Moisture Regime Class in Each Vegetation Type Rangewide and in the Eastern and Western Regions}

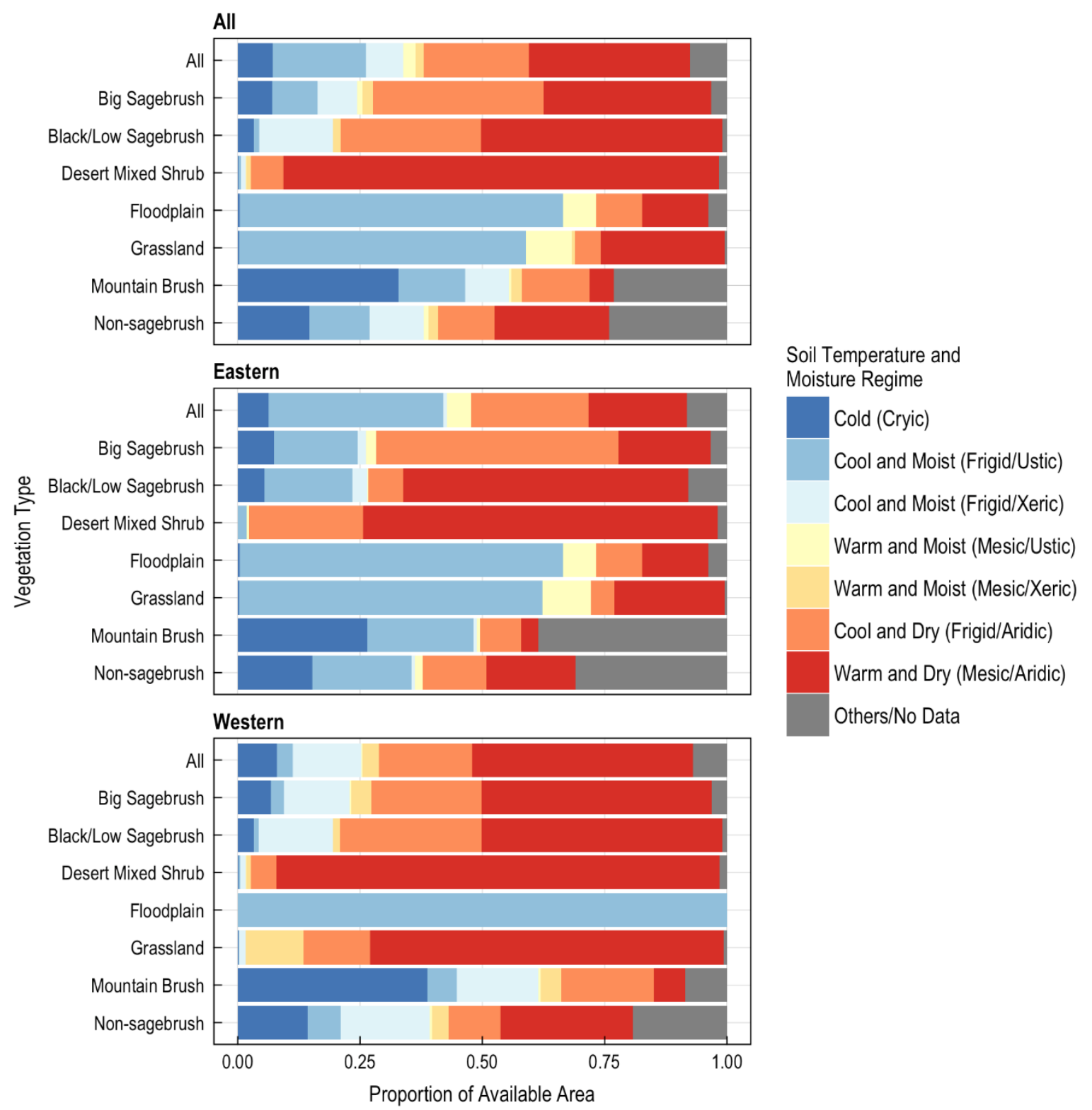




\section{Appendix 8. Limitations of Fire Point Occurrence, Burn Severity, and Fire Perimeter Data}

Fire data are typically available in point occurrence, burn severity, and fire perimeter formats. Point occurrence data include various attributes included in fire agency reports (size, cause, dates, etc.), which are typically georeferenced to the estimated point of origin of a fire. Many older records only reference the fire location using the Public Land Survey System (that is, township, range, section), and early electronic databases limited the spatial resolution at which locations were recorded, resulting in points being snapped to a regularly spaced grid. Burn severity data are derived using satellite imagery and stored in raster format at the pixel resolution associated with the satellite sensors they were derived from. Burn severity is estimated using satellite-sensor evidence of fire consumption rates of both living and dead plants which are used to infer fire severity or the magnitude of the effect that fire has on the environment (Sugihara and others, 2006). Fire perimeter data were traditionally produced by sketching estimated fire boundaries onto paper maps, manually interpreting them from aerial photographs, or connecting a series of GPS points generated by walking or flying around the fire perimeter. More recently, fire perimeters have been generated by digitizing raster-based imagery, especially burn severity data. Each of these source of fire data have their limitations that must be fully understood to avoid inappropriate uses. Some of their primary limitations are described below, in addition to our reasoning for only utilizing one type in this study, specifically fire perimeter data derived from rasterbased satellite imagery.

\section{Limitations of Fire Point Occurrence Data}

Point occurrence data have the advantage of encompassing all fires, regardless of size. However, they have many characteristics that limit their utility. Although point data may be relatively complete for areas under Federal jurisdiction, they are often less complete for other areas, especially private lands. Thus, as the spatial scope of an area increases encompassing multiple management types (for example Federal, State, local, and private jurisdictions), so too does the internal consistency of the point occurrence data. The wide range of proportions of governmental lands versus private lands among the management zones in this study (appendix 2) would confound comparisons among these zones if point data were to be used. The areas associated with each fire record also are only estimates of total fire area and not actual burned area, because unburned inclusions are not quantified. The methodologies used to estimate fire area can vary among fires and among years based on variable reporting standards and evolving technologies. Reported fire areas can sometimes: (1) alternatively represent the containment area rather than actual fire area; (2) extend to include outlying spots as contiguous in the fire boundaries; (3) be incomplete and estimated before the end of burning; and (4) be reported only in public agency boundaries. Point data also often contain errors associated with the initial recording, or subsequent transcription from paper to electronic records, of the point of origin of a fire. Point datasets also can contain redundancies, such as the same fire being reported by multiple responding agencies that can affect derived statistics such as fire area. Additionally, because points are one dimensional, the area they conceptually represent can not be readily parsed using other fine-scale spatial data (for example vegetation types or soil temperature and moisture regimes). The most comprehensive and annually updated online source of point data in the Western United States is the Federal Wildland Fire Occurrence database (http://wildfire.cr.usgs.gov/firehistory/data.html), and the metadata for these point data contain explicit warnings regarding potential errors and limitations of their use. 


\section{Limitations of Burn Severity Data}

Burn severity data have the advantage of providing precise estimates of actual burned area based on the resolution of the satellite sensors. These data are generated on a continuous scale, which is often summarized into thematic severity classes (for example unburned-to-low, low, moderate, high). However, these data have significant limitations, mostly notably associated with inferring burn severity levels from satellite sensor data. It also can be problematic to translate burn severity data that are based largely on estimates of fuel consumption into fire severity estimates, which represents the ecological effects of fire on plant and animal populations and communities, soil characteristics, etc. Additional limitations of burn severity data are discussed in the following section on fire perimeter data as they relate to distinguishing between unburned-to-low and other burn severity classes.

The most comprehensive and consistent source of burn severity data in the United States is produced by the Monitoring Trends in Burn Severity (MTBS) program (http://www.mtbs.gov/). The MTBS program produces burn severity mapping products based on Landsat satellite imagery at $30 \mathrm{~m} \times$ $30 \mathrm{~m}$ resolution dating back to 1984 (Eidenshink and others, 2007). This database includes the majority of fires $\geq 405$ ha (1,000 acres) that have occurred in the Western United States. Various fire reports and other records from Federal and State sources are used by MTBS program staff to guide their searches for fire perimeters on satellite imagery. Thus, although the MTBS data focus on large fires that occur on Federal lands, they also include most large fires on State lands. The MTBS database also includes many large fires that occur on private lands because large fires typically involve some response by Federal or State fire suppression agencies, in turn generating a fire report likely captured by MTBS.

\section{Limitations of Fire Perimeter Data}

In the past, fire perimeters were generated by relatively imprecise, inaccurate, and variable methods, but more recently the perimeters have been digitized by the MTBS program from more precise and accurate raster imagery using standardized methods for the entire United States. The MTBS perimeter data have far less limitations compared to those described above for point occurrence data, but because they are based on burn severity data, they are limited by most of the same issues associated with that technology.

Virtually all fires have some degree of unburned and partially or lightly burned (that is, low severity) inclusions in their outer perimeter. The term "fire area" rather than "burned area" is sometimes used in reference to the area in a fire perimeter to emphasize that it is not necessarily all burned. An MTBS fire record contains a thematic burn severity raster that includes an unburned-to-low class, which could be removed to potentially generate a more precise calculation of actual burned area in a fire perimeter. This approach is designed to reduce errors of commission, which occur when assuming a pixel in a perimeter was burned when it really was not burned. At least one recent study of fire patterns in the Western United States adopted this approach to reduce errors of commission (Abatzoglou and Kolden, 2013). However, this approach can lead to equally concerning errors of omission, which occur when assuming a pixel was unburned when it really was burned. Both of these types of errors can occur in MTBS burn severity products, or derivations of them.

A recent study by Sparks and others (2014) evaluated burned/unburned classification accuracies of MTBS products compared with visual interpretations of false color Landsat composites. The focus was on four fires in sagebrush steppe in the Northern Great Basin that ranged in the degree to which they had unburned inclusions. One fire had few actual unburned inclusions, another had some unburned areas, and the other two had many unburned areas. The MTBS fire product with few unburned inclusions had 98\% accuracy, with 4\% errors of commission and 5\% errors of omission of burned areas (Sparks and others, 2014, table 1). The other three fire perimeters for fires with moderate to high 
amounts of unburned area had 94-97\% accuracy, with 8-16\% errors of commission and 5-8\% errors off omission of burned areas. Adjusting the MTBS fire perimeters by removing unburned inclusions (unburned-to-low thematic class) decreased errors of commission, but increased errors of omission, resulting in negligible changes in overall accuracy (Sparks and others, 2014). The take home message was that attempts to increase precision of burned area estimates by removing unburned-to-low pixels may not substantially improve overall accuracy in sagebrush steppe, and may simply replace overestimates with underestimates of fire area.

The accuracy of burn severity products also can differ greatly among those derived from postfire satellite imagery taken 1 month, 1 year, and 2 years post-fire (Strand and others, 2013, table 2). In sagebrush steppe, a significant correlation of severity estimates with on-the-ground composite burn index (CBI) values was only observed for imagery captured within a month following the fire, and not with imagery from 1 or 2 years post-fire (Strand and others, 2013). It was explained that in areas burned at low to moderate severity in sagebrush steppe, the regrowth of vegetation during the initial growing seasons following fire can produce enough biomass to look very similar to unburned areas, and therefore be classified as such using imagery captured 1 or 2 years post-fire. The implications are that burn severity products generated using post-fire imagery beyond the growing season in which the fire occurred may include substantial misclassifications of actual burned pixels as being unburned, leading to increased errors of omission.

MTBS protocols call for using post-fire imagery from the current growing season (called an "initial assessment") when a fire occurs primarily in herbaceous and/or non-resprouting shrubland vegetation and imagery from the subsequent growing season (called an "extended assessment") in all other vegetation types. The prairie, steppe, and shrubland fires included in the current study were characterized by MTBS staff using a mix of initial ( $70 \%$ of fires) and extended (30\% of fires) assessment data, even though one would have thought that only initial assessment data would have been used. The $30 \%$ of fires that used extended assessment imagery in our study also encompassed larger expanses of Non-Sagebrush types for which extended assessments were deemed most appropriate (for example woodlands and forests). This is a common limitation of analyzing only portions of fires. As would be predicted, across the fire areas in our study we found much higher proportions of unburned-tolow pixels in extended assessment compared to initial assessment fires $113 \%$ unburned-to-low pixels in initial and 35\% in extended assessment fires for areas in the Big Sagebrush, Black and Low Sagebrush, and Grassland vegetation types where initial assessment would be most appropriate). This observation corroborates the conclusion that some areas that actually burned were likely classified as unburned when using extended assessment imagery in our study area. 


\section{Appendix 9. Annual Precipitation Means (in millimeters per year) over the Long Term (1895-2013) and in the Years Encompassed by the Fire Data (1984-2013)}

\begin{tabular}{lccc}
\hline \multicolumn{1}{c}{ Management Zone } & $\begin{array}{c}\text { Long-term } \\
(\mathbf{1 8 8 5 - 2 0 1 3 )}\end{array}$ & $\begin{array}{c}\text { Fire data years } \\
(\mathbf{1 9 8 4 - 2 0 1 3 )})\end{array}$ & $\begin{array}{c}\text { Deviation from } \\
\text { long-term }\end{array}$ \\
\hline Columbia Basin & Western Management Zones & \\
Northern Great Basin & 250 & 250 & 0.1 \\
Snake River Plain & 316 & 317 & 0.1 \\
Southern Great Basin & 362 & 364 & 0.5 \\
\hline & 323 & 328 & 1.5 \\
\hline Colorado Plateau & Eastern Management Zones & \\
Great Plains & 395 & 414 & 4.6 \\
Wyoming Basin & 357 & 365 & 2.1 \\
\hline
\end{tabular}




\section{Appendix 10. Annual Precipitation Means (mm/yr) During Each of the 30 Years of the Study (1984-2013) Compared with the Previous 117 Years (1895-2012)}

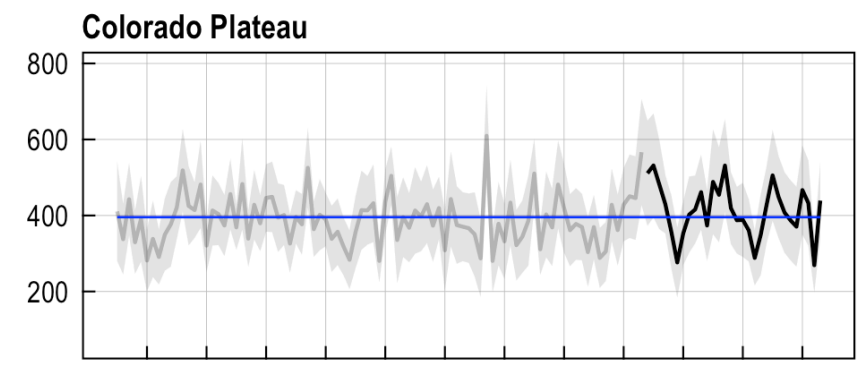

190019101920193019401950196019701980199020002010
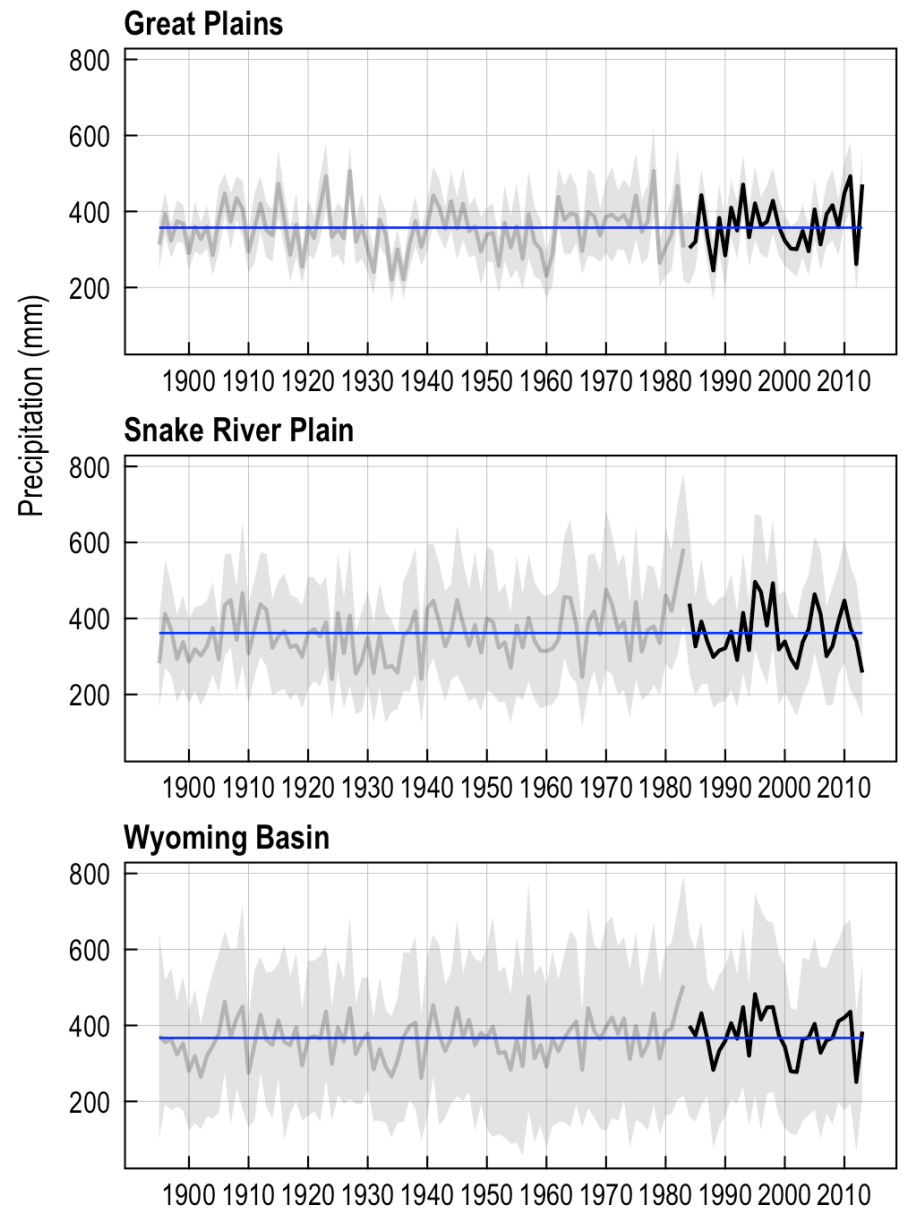

Columbia Basin

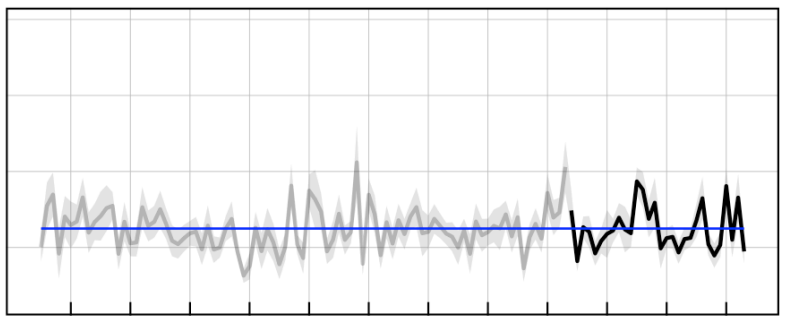

190019101920193019401950196019701980199020002010 Northern Great Basin

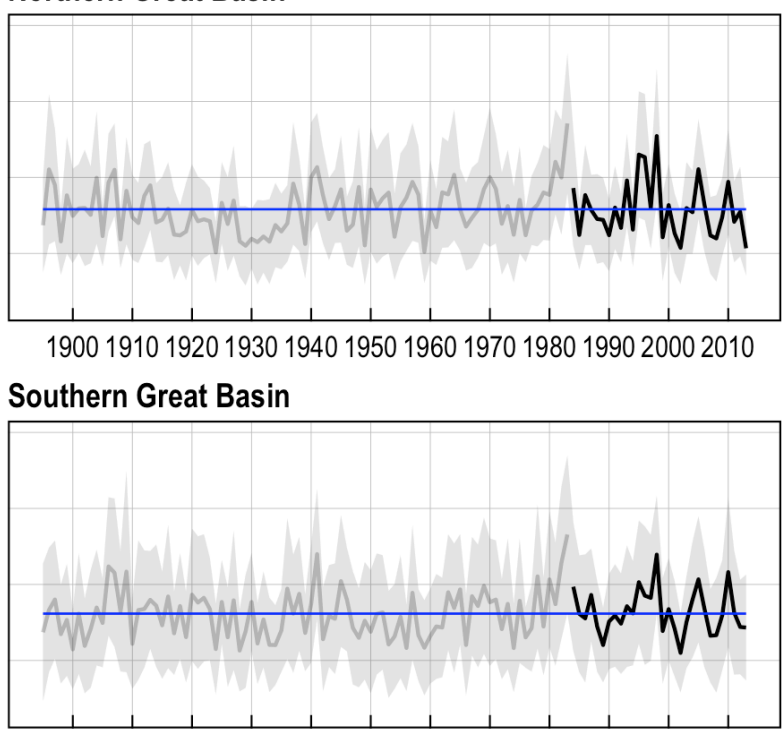

190019101920193019401950196019701980199020002010 


\section{Appendix 11. Proportion of Fire Area Represented by Each Soil Temperature and Moisture Regime Class in Each Vegetation Type Rangewide}

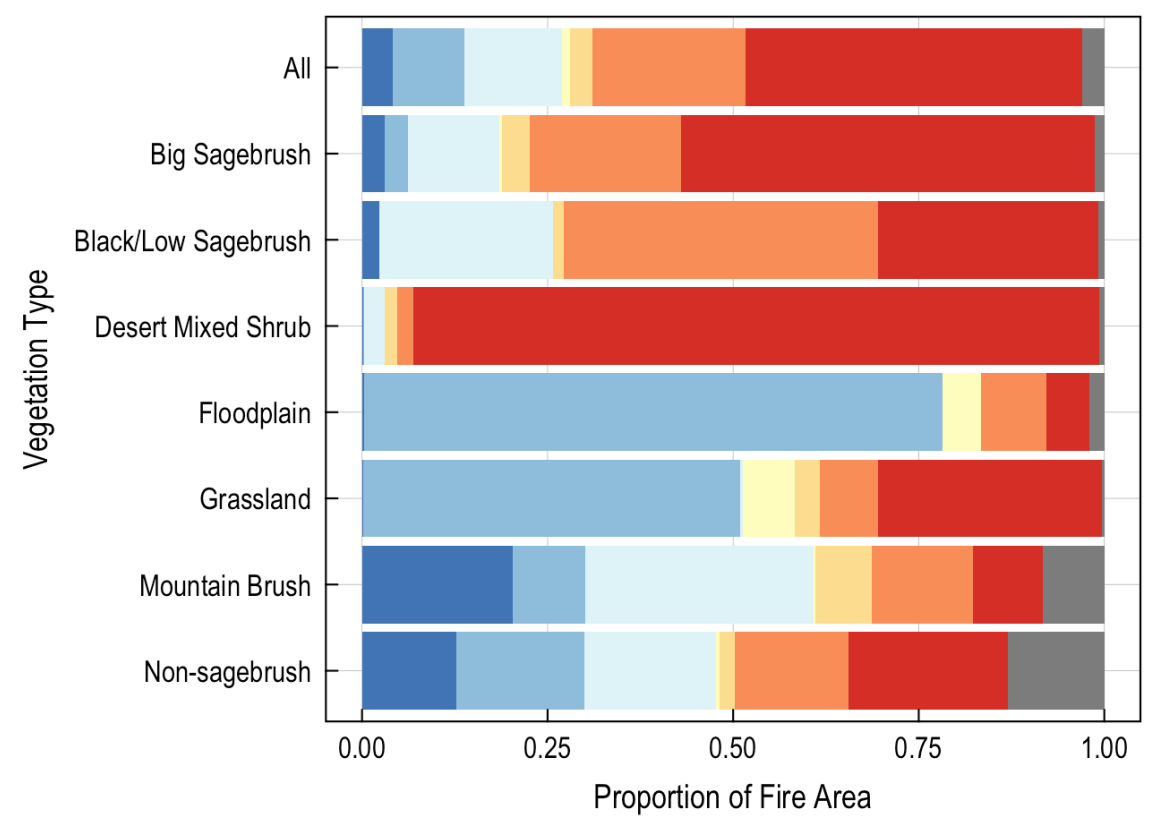

Soil Temperature and

Moisture Regime

Cold (Cryic)

Cool and Moist (Frigid/Ustic)

Cool and Moist (Frigid/Xeric)

Warm and Moist (Mesic/Ustic)

Warm and Moist (Mesic/Xeric)

Cool and Dry (Frigid/Aridic)

Warm and Dry (Mesic/Aridic)

Others/No Data 


\section{Appendix 12. Proportion of Fire Area Represented by Each Soil Temperature and Moisture Regime Class in Each Vegetation Type in Each Greater Sage- Grouse Management Zone in the Western Region}

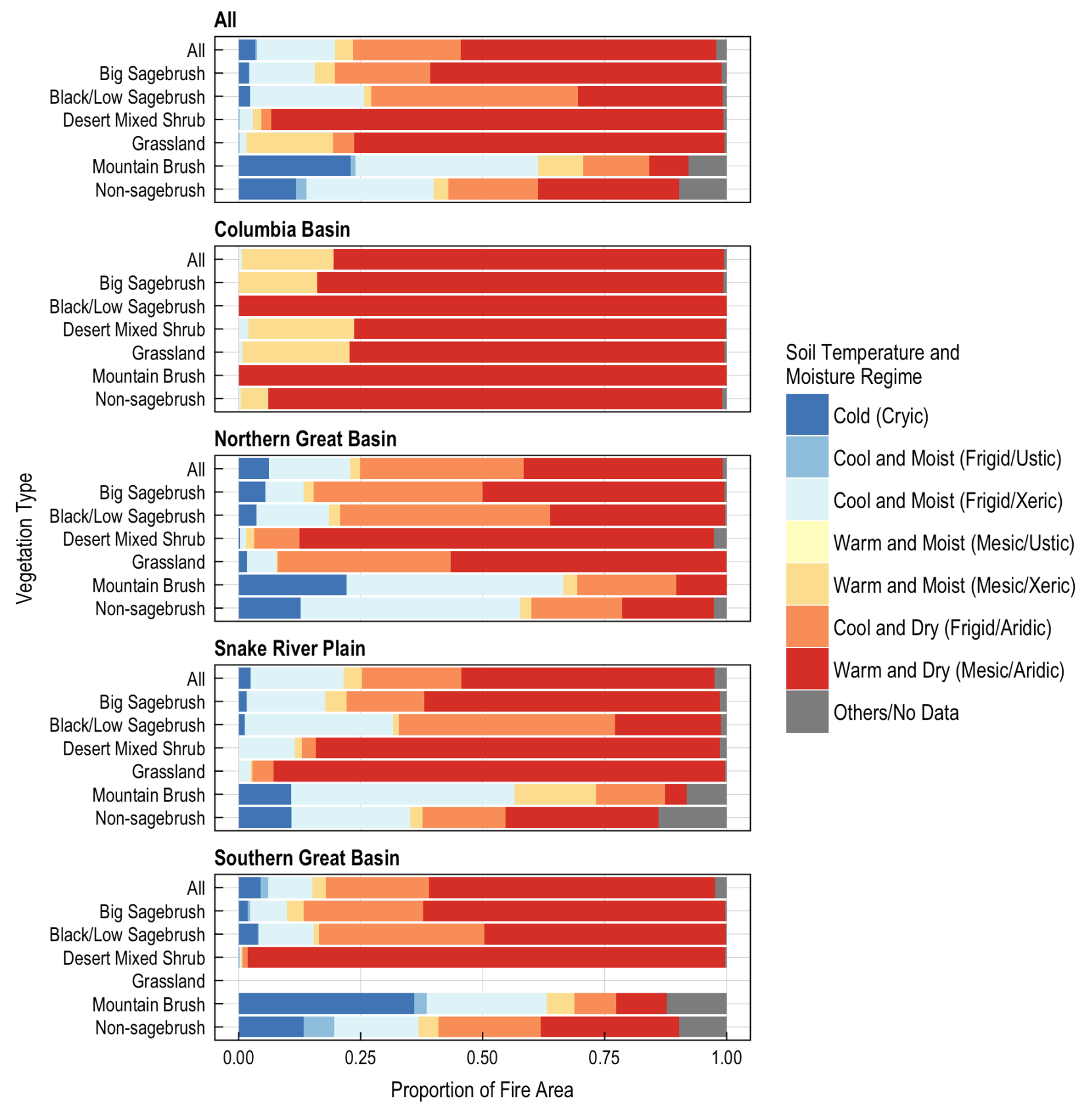




\section{Appendix 13. Proportion of Fire Area Represented by Each Soil Temperature and Moisture Regime Class in Each Vegetation Type in Each Greater Sage- Grouse Management Zone in the Eastern Region}

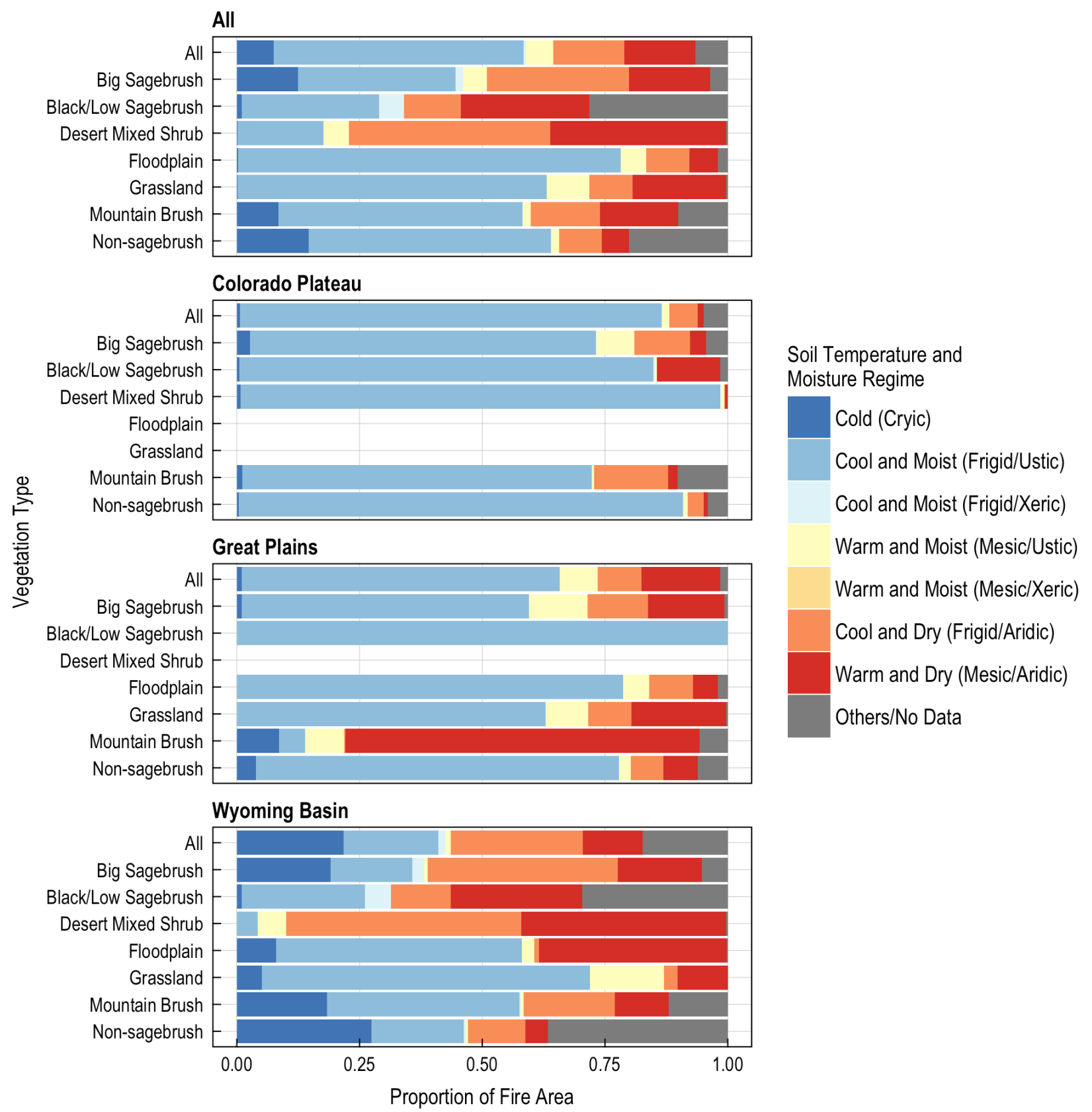


Publishing support provided by the U.S. Geological Survey

Science Publishing Network, Tacoma Publishing Service Center

For more information concerning the research in this report, contact the Director, Western Ecological Research Center

U.S. Geological Survey

3020 State University Drive East

Sacramento, California 95819

http://werc.usgs.gov/ 
